\title{
Stratigraphy and Paleogeographic Significance of the Pennsylvanian-Permian Bird Spring Formation in the Ship Mountains, Southeastern California
}

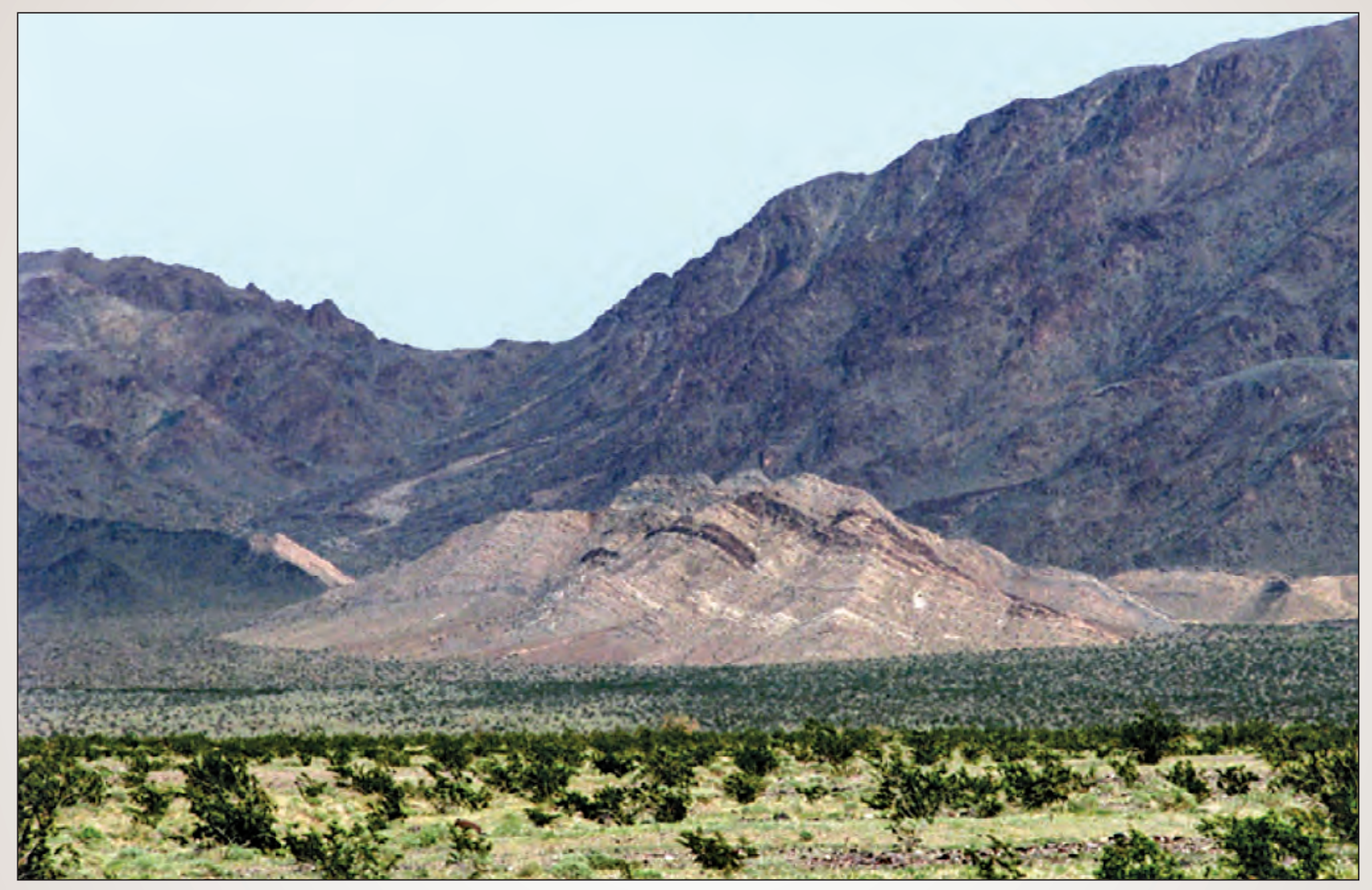

Scientific Investigations Report 2013-5109 
COVER:

View of western side of Ship Mountains, California, showing light-colored carbonate rocks and dark-brown sandstone of the Pennsylvanian-Permian Bird Spring Formation. Massive dark rocks in background are part of a Late Jurassic granitoid pluton.

Photograph by Paul Stone, U.S. Geological Survey. 


\section{Stratigraphy and Paleogeographic Significance of the Pennsylvanian-Permian Bird Spring Formation in the Ship Mountains, Southeastern California}

By Paul Stone, Calvin H. Stevens, Keith A. Howard, and Thomas D. Hoisch

Scientific Investigations Report 2013-5109 


\title{
U.S. Department of the Interior SALLY JEWELL, Secretary
}

\section{U.S. Geological Survey \\ Suzette M. Kimball, Acting Director}

\author{
U.S. Geological Survey, Reston, Virginia: 2013
}

For more information on the USGS - the Federal source for science about the Earth, its natural and living resources, natural hazards, and the environment, visit http://www.usgs.gov or call 1-888-ASK-USGS.

For an overview of USGS information products, including maps, imagery, and publications, visit http://www.usgs.gov/pubprod

To order this and other USGS information products, visit http://store.usgs.gov

Any use of trade, firm, or product names is for descriptive purposes only and does not imply endorsement by the U.S. Government.

Part or all of this report is presented is Portable Document Format (PDF). For best results viewing and printing PDF documents, it is recommended that you download the documents to your computer and open them with Adobe Reader. PDF documents opened from your browser may not display or print as intended. Download the latest version of Adobe Reader, free of charge.

Suggested citation:

Stone, Paul, Stevens, C.H., Howard, K.A., and Hoisch, T.D., 2013, Stratigraphy and paleogeographic significance of the Pennsylvanian-Permian Bird Spring Formation in the Ship Mountains, southeastern California: U.S. Geological Survey Scientific Investigations Report 2013-5109, 40 p., http://dx.doi.org/10.3133/sir20135109.

ISSN 2328-0328 (online) 


\section{Contents}

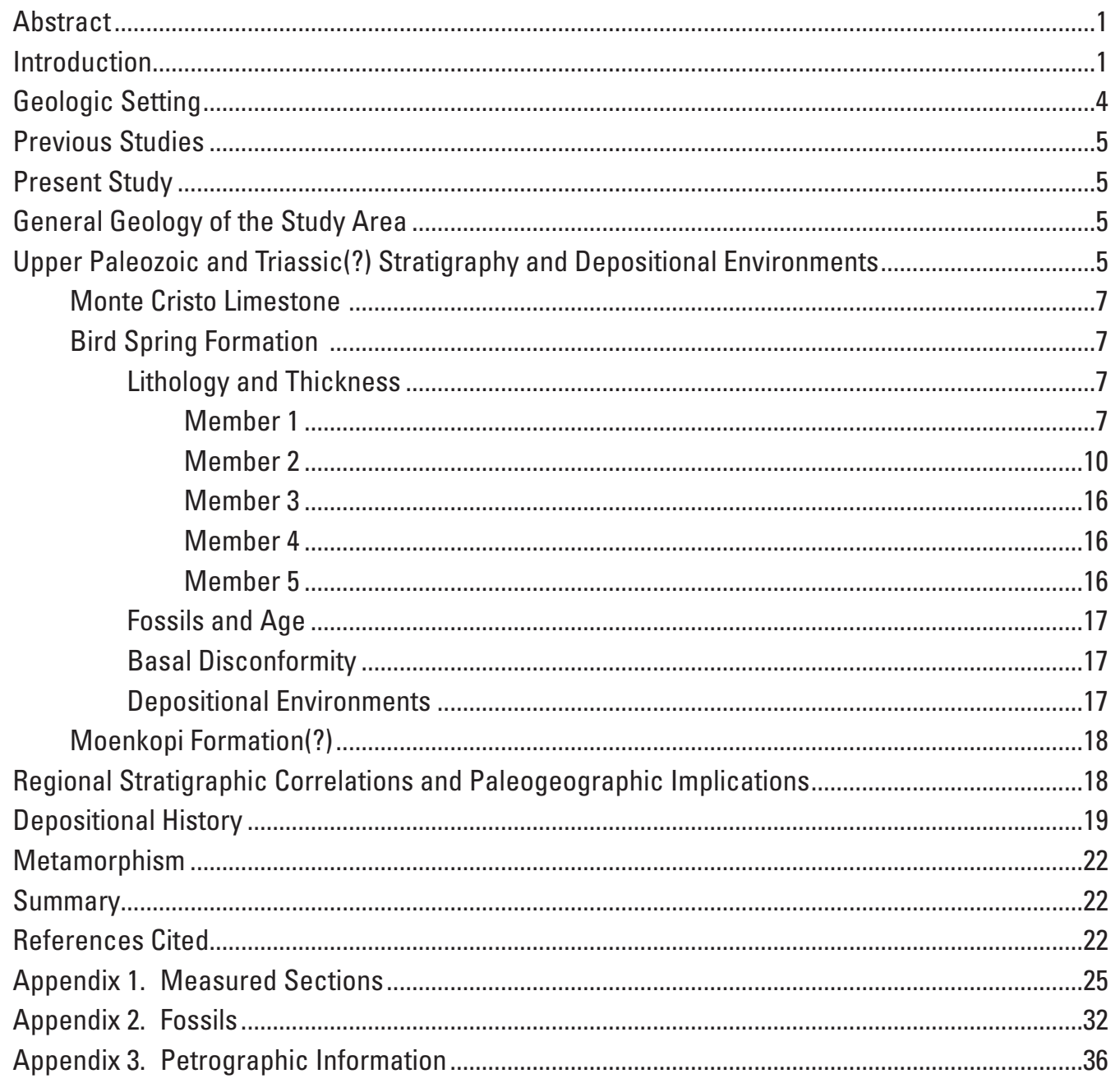

\section{Plate}

1. Stratigraphic columns for measured sections SM and SM2, Ship Mountains, southeastern California.

\section{Figures}

1. Map showing outcrop distribution of upper Paleozoic (Mississippian to Permian) sedimentary rocks in southeastern California, southern Nevada, and western Arizona

2. Chart showing geologic age terms relevant to this report and regional ages of the Mississippian Monte Cristo Limestone and Pennsylvanian to lower Permian Bird Spring Formation

3. Map showing geologic setting of the Ship Mountains area ........................................... 


\section{Figures-Continued}

4. Geologic map and cross section of upper Paleozoic and associated rocks on the west side of the Ship Mountains

5. Digital orthophoto of map area and simplified geology on orthophoto base

6. Generalized stratigraphic column of upper Paleozoic and Triassic(?) rocks in the Ship Mountains based primarily on measured sections SM and SM2

7. Annotated field photographs of upper Paleozoic rocks in the Ship Mountains

8. Outcrop photographs of upper Paleozoic and Triassic(?) rocks in the Ship Mountains

9. Fusulinids from the Bird Spring Formation in the Ship Mountains

10. Corals and fusulinids from the Bird Spring Formation in the Ship Mountains 15

11. Simplified stratigraphic columns illustrating regional correlations between upper Paleozoic and Triassic(?) rocks in the Ship Mountains and coeval rocks in the Providence Mountains, the Blythe area, and the Virgin Mountains

12. Upper Paleozoic outcrop map of southeastern California, southern Nevada, and northwestern Arizona showing interpreted paleogeographic boundary between the Pennsylvanian to early Permian Bird Spring Shelf and the coeval cratonal platform to the southeast

\section{Tables}

1. Fossils from map localities 1-6, Ship Mountains

2. Fusulinids and other foraminifera from measured section SM, Bird Spring Formation, Ship Mountains

\section{Conversion Factors and Datum}

Conversion Factors

SI to Inch/Pound

\begin{tabular}{lcl}
\multicolumn{1}{c}{ Multiply } & \multicolumn{1}{c}{ By } & \multicolumn{1}{c}{ To obtain } \\
\hline & Length & \\
\hline meter $(\mathrm{m})$ & 3.281 & foot $(\mathrm{ft})$ \\
kilometer $(\mathrm{km})$ & 0.6214 & mile (mi) \\
\hline
\end{tabular}

Temperature in degrees Celsius $\left({ }^{\circ} \mathrm{C}\right)$ may be converted to degrees Fahrenheit $\left({ }^{\circ} \mathrm{F}\right)$ as follows:

$$
{ }^{\circ} \mathrm{F}=\left(1.8 \mathrm{x}^{\circ} \mathrm{C}\right)+32
$$

Datum

Horizontal coordinate information is referenced to the North American Datum of 1927 (NAD 27). 


\title{
Stratigraphy and Paleogeographic Significance of the Pennsylvanian-Permian Bird Spring Formation in the Ship Mountains, Southeastern California
}

\author{
By Paul Stone, ${ }^{1}$ Calvin H. Stevens, ${ }^{2}$ Keith A. Howard, ${ }^{1}$ and Thomas D. Hoisch ${ }^{3}$
}

\section{Abstract}

A thick sequence of limestone, dolomite, and minor sandstone assigned to the Pennsylvanian and lower Permian Bird Spring Formation is exposed in the Ship Mountains about 85 kilometers $(\mathrm{km})$ southwest of Needles, California, in the eastern Mojave Desert. These strata provide a valuable reference section of the Bird Spring Formation in a region where rocks of this age are not extensively exposed. This section, which is about 900 meters (m) thick, is divided into five informal members:

1. A lower member of thick-bedded to massive limestone and dolomite (180 m thick);

2. A limestone and dolomite member (200 m thick) lithologically similar to member 1 , but separated from member 1 by a fault of undetermined offset;

3. A member of sandy limestone, calcareous sandstone, quartzite, and minor limestone (80 m thick);

4. A thick-bedded to massive, fossiliferous limestone member (55 m thick); and

5. An upper member of thin- to thick-bedded dolomite, limestone, silty to sandy limestone, and quartzose sandstone (385 m thick).

Member 1 contains conodonts and other fossils of Early Pennsylvanian age; member 4 and the lower part of member 5 contain fusulinids of early Permian age. Member 4 also contains early Permian corals. Member 1 overlies Mississippian limestone assigned to the Monte Cristo Limestone, and member 5 is overlain by sandstone questionably assigned to the Lower Triassic Moenkopi Formation. The contact between the Bird Spring and Moenkopi(?) Formations is obscured by Quaternary alluvium and a Jurassic(?) dike.

${ }^{1}$ U.S. Geological Survey.

${ }^{2}$ San Jose State University.

${ }^{3}$ Northern Arizona University.
Strata of the Bird Spring Formation in the Ship Mountains originated as shallow-water marine deposits on the broad, southwest-trending continental shelf of western North America. Perpendicular to the shelf, the paleogeographic position of the Ship Mountains section is intermediate between those of the thicker, less terrigenous, more seaward section of the Bird Spring Formation in the Providence Mountains, $55 \mathrm{~km}$ to the northwest, and the thinner, more terrigenous, more landward sections of the Supai Group near Blythe, $100 \mathrm{~km}$ to the southeast. Parallel to the shelf, the Ship Mountains section is comparable in lithofacies and inferred paleogeographic position to sections assigned to the Callville Limestone and overlying Pakoon Limestone in northwestern Arizona and southeastern Nevada, $250 \mathrm{~km}$ to the northeast.

Deposition of the Bird Spring Formation followed a major rise in eustatic sea level at about the MississippianPennsylvanian boundary. The subsequent depositional history was controlled by episodic changes in eustatic sea level, shelf subsidence rates, and sediment supply. Subsidence rates could have been influenced by coeval continental-margin tectonism to the northwest.

\section{Introduction}

Upper Paleozoic sedimentary rocks, including Pennsylvanian and lower Permian (Cisuralian) rocks assigned to the Bird Spring Formation and correlative units, are widespread in southeastern California, southern Nevada, and western Arizona (fig. 1). Pennsylvanian and lower Permian rocks in this region originated as calcareous and fine-grained siliciclastic sediments on the western continental margin of North America, which included the Bird Spring Shelf of Stevens and Stone (2007) and the adjacent cratonal platform. A long (about 50 m.y.) history of subsidence and sedimentation on the Bird Spring Shelf led to the accumulation of stratigraphic sequences commonly greater than $1 \mathrm{~km}$ and locally in excess of $2 \mathrm{~km}$ thick (McNair, 1951; Rich, 1961; Longwell and others, 1965; Stevens and Stone, 2007). 


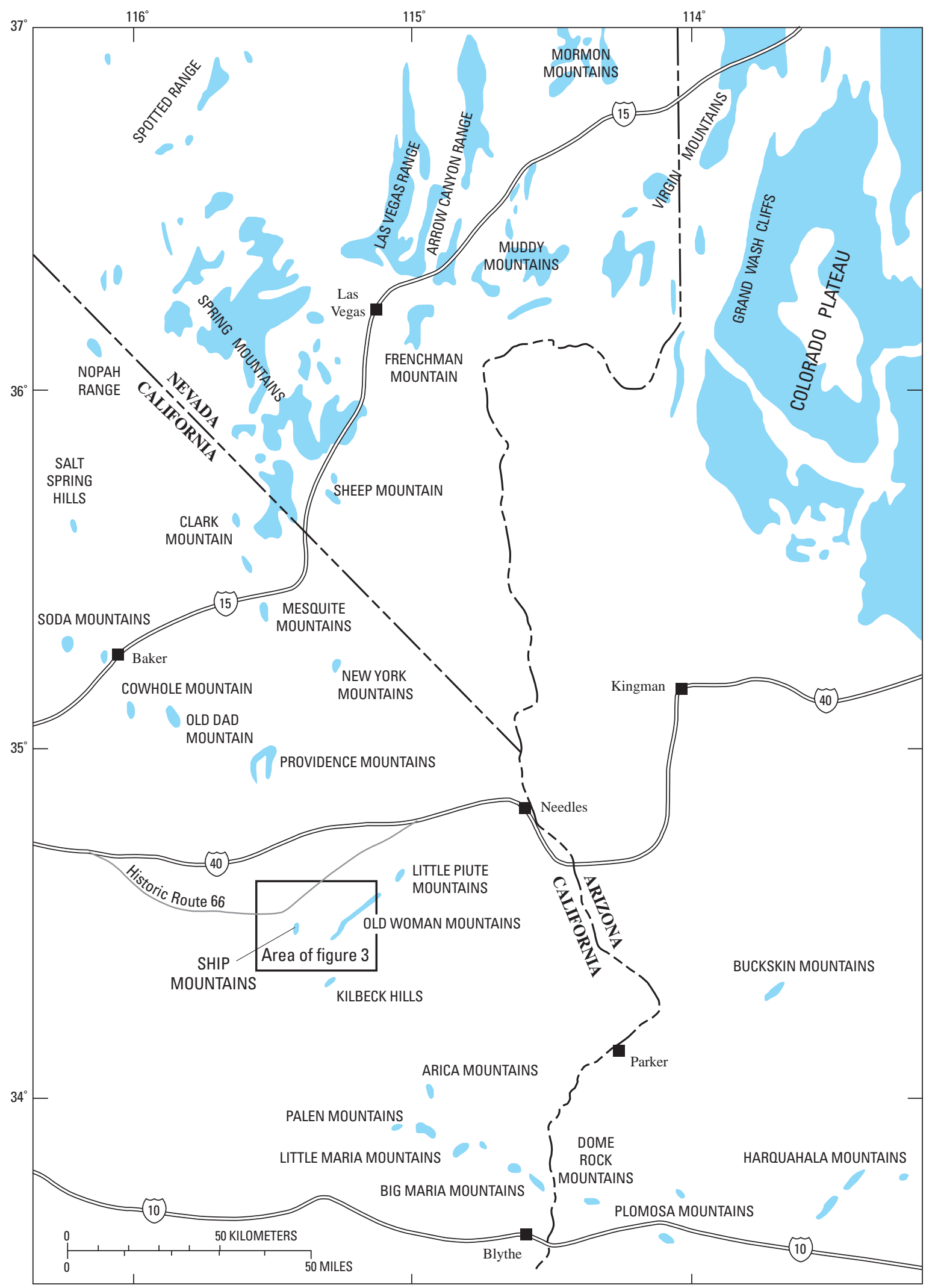

Figure 1. Map showing outcrop distribution of upper Paleozoic (Mississippian to Permian) sedimentary rocks in southeastern California, southern Nevada, and western Arizona. Note location of Ship Mountains in California. Geologic data from Oetking and others (1967), Feray and others (1968), Jennings (1977), Stewart and Carlson (1977), Stone and others (1983), and Richard and others (2000). 
In the Mojave Desert of southeastern California, the Bird Spring Formation and correlative rocks are exposed in several mountain ranges between the vicinities of Baker and Blythe (fig. 1). The Bird Spring Formation near Baker, including the relatively well studied section in the Providence Mountains (Hazzard, 1954), consists primarily of thick-bedded limestone in which fusulinids, corals, and other marine fossils are locally abundant (Thompson and Hazzard, 1946; Stevens and Stone, 2007). These rocks represent open marine depositional conditions on a carbonate shelf largely free from major influxes of terrigenous sediment. By contrast, to the southeast, correlative rocks assigned to the Supai Group in the Big Maria Mountains and other ranges near Blythe (Hamilton, 1982) consist primarily of sandstone, calcareous sandstone, and sandy limestone (generally metamorphosed to quartzite and calc-silicate rocks) that represent a more shoreward depositional environment. This change in lithofacies and depositional setting is inferred to reflect northwestward deepening of the shelf away from a southwest-trending shoreline (Stone and others, 1983; Brown, 1991; Stevens and Stone, 2007).
Several exposures of Pennsylvanian and lower Permian rocks are present between the Providence Mountains and the mountains near Blythe, but most of these are structurally complex and highly metamorphosed (Stone and others, 1983). A structurally simple and less metamorphosed section of Pennsylvanian and lower Permian rocks, however, is exposed in the Ship Mountains approximately $55 \mathrm{~km}$ southeast of the Providence Mountains and $100 \mathrm{~km}$ northwest of the mountains near Blythe (fig. 1). The Ship Mountains section provides an informative glimpse into the nature of the lithologic transition between the Bird Spring limestone facies to the northwest and the Supai sand-rich facies to the southeast.

In this report we present a detailed stratigraphic description of the Pennsylvanian and Permian rocks in the Ship Mountains together with an account of all the fossils presently known from these rocks. We also discuss the regional stratigraphic correlations, paleogeographic implications, depositional history, and metamorphism of these rocks. International and North American geologic age terms relevant to this report are shown in figure 2.

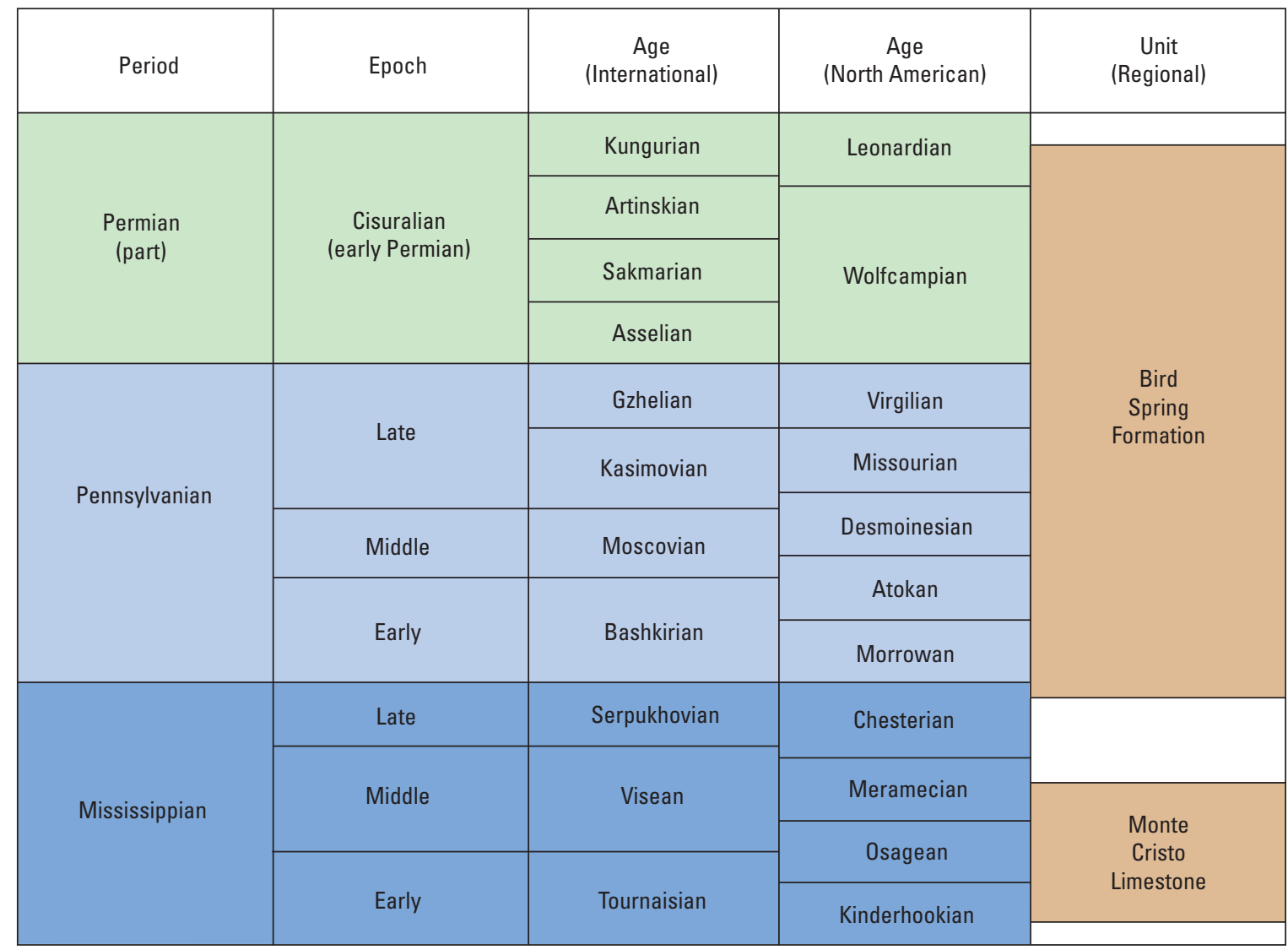

Figure 2. Chart showing geologic age terms relevant to this report and regional ages of the Mississippian Monte Cristo Limestone and Pennsylvanian to lower Permian Bird Spring Formation. Compiled from Langenheim and others (1973), Stevens and others (1996), Davydov and others (2004), Wardlaw and others (2004), Stevens and Stone (2007), Bishop and others (2009), and U.S. Geological Survey Geologic Names Committee (2010). 


\section{Geologic Setting}

The Ship Mountains are a small but rugged range about $85 \mathrm{~km}$ southwest of Needles and $9 \mathrm{~km}$ east of Cadiz, a railroad siding in the central Mojave Desert (iggs. 1, $\underline{3})$. The range is primarily composed of a Late Jurassic ( 145-150 Ma) granitoid pluton that intrudes Paleozoic and Triassic(?) sedimentary rocks and Precambrian crystalline basement rocks on its western and northern margins (Hazzard, 1931; Bishop, 1963; Gerber and others, 1995; this study). Mississippian to Triassic(?) rocks, which are inferred to be separated from Cambrian rocks to the north by a concealed fault (fig. 3), are confined to a small area at the western foot of the range. Tertiary volcanic and sedimentary rocks flank the north margin of the Ship Mountains.
Thermobarometric data indicate that the Jurassic and older rocks of the Ship Mountains are upper crustal rocks that stand in sharp contrast to Cretaceous and older rocks that once resided at considerably greater crustal depths in the Old Woman Mountains (fig. 3 ) only $10 \mathrm{~km}$ to the east (Foster and others, 1992). Based in part on this relation, Carl and others (1991) interpreted the rocks of the Ship Mountains to have been displaced westward from an original structural position above the rocks of the Old Woman Mountains along an extensional shear zone of Late Cretaceous age. This structural interpretation, although unproven, is consistent with the relatively low degree of metamorphism and deformation of the Paleozoic and Triassic(?) rocks in the Ship Mountains compared to that in the Old Woman Mountains.

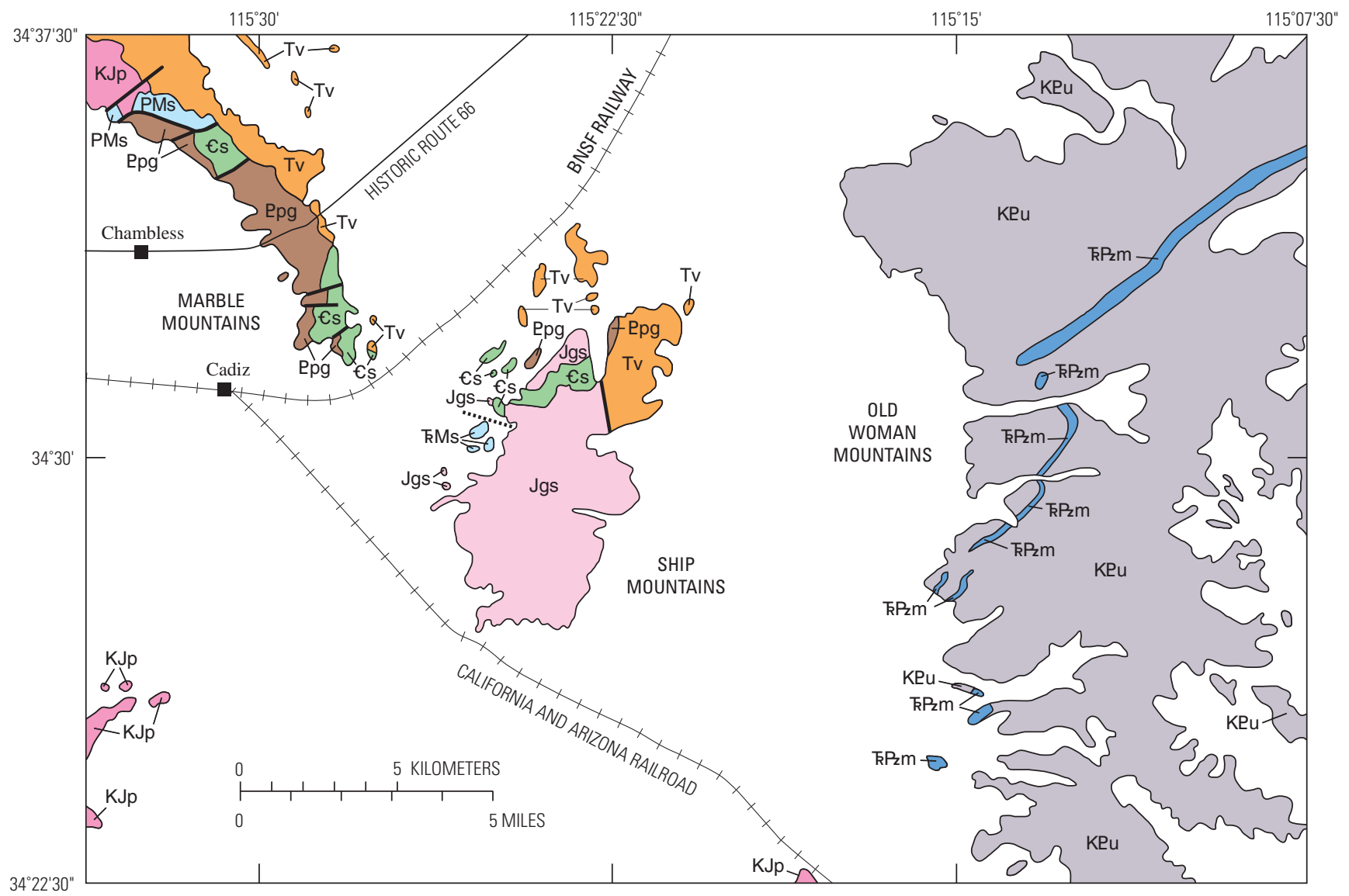

EXPLANATION

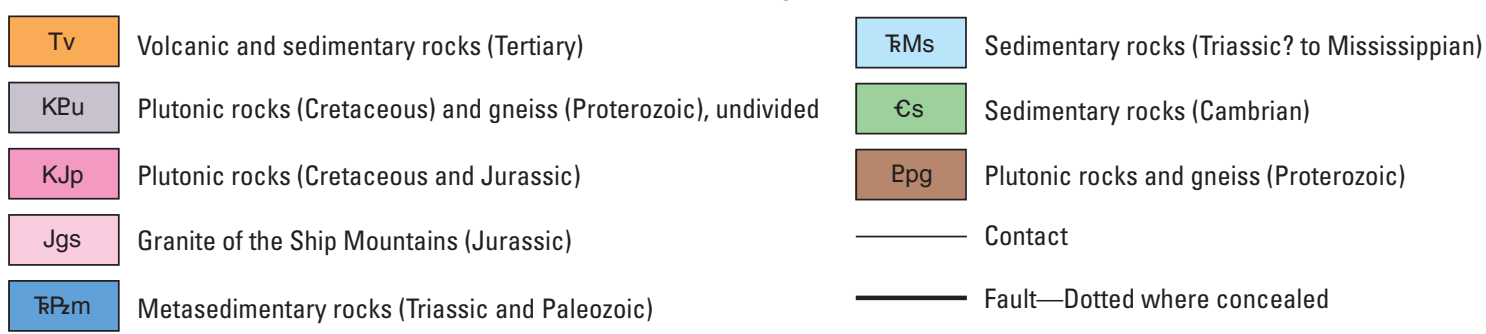

Figure 3. Map showing geologic setting of the Ship Mountains area. Geologic data from Bishop (1963), Miller and others (1982), and Howard (2002). 


\section{Previous Studies}

Pennsylvanian and Permian rocks in the Ship Mountains were first described by Hazzard (1931), who mapped the geology of the area and reported fossils that he interpreted as Pennsylvanian in age from two horizons in the stratigraphic sequence. These rocks were remapped by Collier (1959) who reported the presence of fusulinids that C.W. Merriam (written commun. in Collier, 1959) interpreted as Permian. Bishop (1963) compiled the mapping of Hazzard (1931) and Collier (1959) and assigned the upper part of the Pennsylvanian-Permian sequence in the Ship Mountains to the Bird Spring Formation, leaving the lower part unnamed.

\section{Present Study}

Our study of Pennsylvanian and Permian rocks in the Ship Mountains began with visits to the area by Paul Stone and K.A. Howard in 1978-79. During this time, the upper part of the sequence was measured in detail, and fossils collected were identified by U.S. Geological Survey paleontologists. This work was reported as part of a regional stratigraphic study by Stone and others (1983), who summarized the stratigraphy of the PennsylvanianPermian rocks, noted the presence of Early Pennsylvanian (Morrowan) conodonts and early Permian (Wolfcampian) fusulinids, and assigned the rocks to the Bird Spring Formation based on general lithologic similarity to that formation in the Providence Mountains.

The Ship Mountains study was resumed in 2003 when Paul Stone and C.H. Stevens mapped the geology of the area, made additional fusulinid collections, and noted the presence of early Permian colonial corals. This work was part of a regional Pennsylvanian-Permian biostratigraphic and paleogeographic study based primarily on fusulinids (Stevens and Stone, 2007).

Most recently, in 2010, Paul Stone and C.H. Stevens revisited the Ship Mountains, revised the geologic mapping, and measured the lower part of the Bird Spring Formation, which is faulted against the younger strata that had been measured previously. This work revealed previously unrecognized exposures of the Mississippian Monte Cristo Limestone stratigraphically below the Bird Spring Formation.

This report synthesizes the results of all the work described above, including detailed descriptions of both measured sections (appendix 1), faunal lists from all known fossil localities (tables 1, 2; appendix 2), and petrographic information (appendix 3). A brief discussion of the metamorphism of the upper Paleozoic rocks, based on preliminary petrographic observations by T.D. Hoisch (this study), also is included.

\section{General Geology of the Study Area}

Upper Paleozoic and Triassic(?) rocks are exposed in a group of small hills (informally called hills 1-4) in an area of about $1 \mathrm{~km}^{2}$ on the west side of the Ship Mountains (figs. 4, ). These rocks mainly consist of limestone and dolomite along with subordinate quartzose sandstone, calcareous sandstone, and sandy limestone. Metamorphism has converted some of the pure carbonate rocks to marble, some of the sandy limestone and calcareous sandstone to calc-silicate rocks, and some of the sandstone to quartzite. The generally well bedded rocks strike northeast and dip about 35 to $70^{\circ} \mathrm{SE}$. A northwest-striking, high-angle fault cuts across the strata near the northeast end of hill 1, and dikes cut strata on hills 2 and 3. Otherwise the strata are relatively undisturbed. Quaternary alluvium covers the contact between the upper Paleozoic to Triassic(?) sequence and Jurassic granitic rocks exposed at the foot of the main Ship Mountains block in the southeastern corner of the study area (fig. 4). A patch of Tertiary volcanic rocks that we assign to the Miocene Peach Spring Tuff unconformably overlies strata of the Bird Spring Formation at the north end of hill 2.

\section{Upper Paleozoic and Triassic(?) Stratigraphy and Depositional Environments}

We herein divide Pennsylvanian and Permian rocks assigned to the Bird Spring Formation in the Ship Mountains study area into five informally numbered members (pl. 1; figs. 4, ). Member 1 and the underlying Mississippian Monte Cristo Limestone are exposed northeast of the fault that transects hill 1. Members 2-5 of the Bird Spring Formation are exposed southwest of the fault on hills 1, 2, and 4. Measured section SM2 transects the Monte Cristo Limestone and member 1 of the Bird Spring Formation, and section SM transects members 2-5 of the Bird Spring Formation (pl. 1; figs. 4, $\underline{6}$; appendix 1). The contact between member 5 of the Bird Spring Formation and overlying sandstone, which is herein questionably assigned to the Triassic Moenkopi Formation, is obscured by alluvium between hills 2 and 3, and by a Jurassic(?) dike on the northwestern part of hill 3.

The following descriptions of the upper Paleozoic and Triassic(?) rocks are accompanied by field photographs (figs. 7, ). Fossil information (appendix 2) is summarized in tables 1 and 2; key fossils are illustrated (igs. 9,$\underline{10}$ ). Note that the subdivision of the rocks in this report differs in detail from that of Stevens and Stone (2007), based on our most recent work in the area. 
Table 1. Fossils from map localities 1-6 (fig. 4), Ship Mountains. See appendix 2 for additional information.

\begin{tabular}{|c|c|c|c|c|}
\hline $\begin{array}{c}\text { Map } \\
\text { locality }\end{array}$ & $\begin{array}{c}\text { Map } \\
\text { unit }\end{array}$ & $\begin{array}{c}\text { Field } \\
\text { locality }\end{array}$ & Fossils & Age \\
\hline 1 & $\mathrm{Mmb}$ & $2010-5$ & $\begin{array}{l}\text { Corals: } \\
\text { Diphyphyllum aff. D. lateseptatum }\end{array}$ & $\begin{array}{l}\text { Middle } \\
\text { Mississippian } \\
\text { (Visean) }\end{array}$ \\
\hline 2 & $\mathrm{Mmb}$ & $\begin{array}{c}\text { S79SM-6 } \\
(27474-\mathrm{PC})^{1}\end{array}$ & $\begin{array}{l}\text { Corals: } \\
\quad \text { Poorly preserved solitary corals }\end{array}$ & Mississippian? \\
\hline \multirow[t]{2}{*}{3} & \multirow[t]{2}{*}{$\mathrm{Pb}_{1}$} & $\begin{array}{c}\text { S79SM-1 } \\
(27476-\mathrm{PC})^{1}\end{array}$ & $\begin{array}{l}\text { Bryozoans: } \\
\text { Rhombopora? sp. } \\
\text { Conodonts } \\
\text { Adetognathus cf. A. spathus } \\
\text { Declinognathodus noduliferus } \\
\text { Idiognathodus delicatus } \\
\text { Idiognathodus convexus } \\
\text { Neognathodus bassleri } \\
\text { Ostracodes } \\
\text { Cavellina sp. } \\
\text { Brachiopods } \\
\text { Neochonetes? sp. } \\
\text { Anthracospirifer cf. A. curvilateralis } \\
\text { Cleiothyridina cf. C. milleri } \\
\end{array}$ & \multirow{2}{*}{$\begin{array}{l}\text { Early Pennsylvaniar } \\
\text { (Morrowan) }\end{array}$} \\
\hline & & $\begin{array}{c}\text { S79SM-2 } \\
(27475-\mathrm{PC})^{1}\end{array}$ & $\begin{array}{l}\text { Conodonts } \\
\text { Adetognathus spp. } \\
\text { Declinognathodus noduliferus } \\
\text { Idiognathodus delicatus } \\
\text { cf. Idiognathoides convexus } \\
\text { Neognathodus bassleri } \\
\text { Rachistognathus sp. } \\
\text { Ostracodes } \\
\text { Cavellina sp. } \\
\text { Brachiopods } \\
\text { Anthracospirifer cf. A. curvilateralis } \\
\text { Composita cf. C. ovata } \\
\text { Cleiothryridina? sp. }\end{array}$ & \\
\hline 4 & $\mathrm{~Pb}_{4}$ & $\begin{array}{l}\text { KH78-87 } \\
(\mathrm{f} 14071)^{1}\end{array}$ & $\begin{array}{l}\text { Fusulinids and other foraminifera: } \\
\text { Climacammina sp. } \\
\text { Pseudofusulinella sp. } \\
\text { Schubertella aff. S. kingi } \\
\text { Schwagerina cf. S. aculeata } \\
\text { Schwagerina aculeata plena }\end{array}$ & $\begin{array}{l}\text { Early Permian } \\
\text { (Wolfcampian) }\end{array}$ \\
\hline \multirow{4}{*}{5} & \multirow{4}{*}{$\mathrm{Pb}_{4}$} & $\begin{array}{l}\text { KH78-89 } \\
(f 14073)^{1}\end{array}$ & $\begin{array}{l}\text { Fusulinids and other foraminifera: } \\
\text { Climacammina sp. } \\
\text { Schubertella sp. } \\
\text { Schwagerina aculeata } \\
\text { Schwagerina wellsensis } \\
\text { Pseudoschwagerina sp. } \\
\text { Stewartina uber } \\
\text { Stewartina sp. } 1 \text { of Stevens and Stone (2007) }\end{array}$ & \multirow{4}{*}{$\begin{array}{l}\text { Early Permian } \\
\text { (Wolfcampian) }\end{array}$} \\
\hline & & S-1945 & $\begin{array}{l}\text { Fusulinids: } \\
\text { Schwagerina aculeata } \\
\text { Schwagerina cf. S. pugunculus } \\
\text { Schwagerina sp. } 4 \text { of Stevens and Stone (2007) } \\
\text { Paraschwagerina elongata }\end{array}$ & \\
\hline & & S-1948 & $\begin{array}{l}\text { Fusulinids: } \\
\quad \text { Pseudoschwagerina arta } \\
\end{array}$ & \\
\hline & & SJS-1366 & $\begin{array}{l}\text { Corals: } \\
\text { Tschussovskenia connorsensis } \\
\text { Protowentzelella kunthi }\end{array}$ & \\
\hline 6 & $\mathrm{~Pb}_{5}$ & S-1947 & $\begin{array}{l}\text { Fusulinids: } \\
\text { Schwagerina cf. S. wellsensis } \\
\text { Schwagerina sp. } 3 \text { of Stevens and Stone (2007) }\end{array}$ & $\begin{array}{l}\text { Early Permian } \\
\text { (Wolfcampian) }\end{array}$ \\
\hline
\end{tabular}

${ }^{1}$ U.S. Geological Survey fossil locality number. 
Table 2. Fusulinids and other foraminifera from measured section SM, Bird Spring Formation, Ship Mountains. All samples indicate an early Permian (Wolfcampian) age. See appendix 2 for additional information.

\begin{tabular}{|c|c|c|c|c|c|}
\hline \multirow{2}{*}{$\begin{array}{l}\text { Sample } \\
\text { number }\end{array}$} & \multirow{2}{*}{$\begin{array}{l}\text { USGS } \\
\text { locality } \\
\text { number }\end{array}$} & \multirow{2}{*}{ Member $^{1}$} & \multicolumn{2}{|c|}{ Meters above base of } & \multirow{2}{*}{ Fusulinids and other foraminifera } \\
\hline & & & Member & Section & \\
\hline SM-18 & f14063 & \multirow{6}{*}{4} & 12 & 235 & $\begin{array}{l}\text { Climacammina sp. } \\
\text { Pseudofusulinella? sp. } \\
\text { Schubertella aff. S. kingi } \\
\text { Schwagerina aculeata } \\
\text { Schwagerina cf. S. aculeata } \\
\text { Schwagerina longissimoidea }\end{array}$ \\
\hline SM-23 & f14064 & & 41 & 264 & Unidentified recrystallized fusulinids \\
\hline SM-24 & f14065 & & 48 & 271 & $\begin{array}{l}\text { Schwagerina? sp. } \\
\text { Pseudoschwagerina? sp. }\end{array}$ \\
\hline SM-25 & f14066 & & 49 & 272 & Schwagerina providens? \\
\hline SM-27 & f14067 & & 50 & 273 & $\begin{array}{l}\text { Climacammina sp. } \\
\text { Schubertella sp. } \\
\text { Schwagerina providens } \\
\text { Schwagerina cf. S. wellsensis } \\
\text { Stewartina multispira }\end{array}$ \\
\hline SM-28 & f14068 & & 53 & 276 & Unidentified recrystallized fusulinids \\
\hline SM-33 & f14069 & \multirow[b]{2}{*}{5} & 33 & 312 & Pseudoschwagerina? sp. \\
\hline SM-35 & $\mathrm{f} 10470$ & & 52 & 331 & $\begin{array}{l}\text { Schwagerina cf. S. wellsensis } \\
\text { Cuniculinella mojavensis }\end{array}$ \\
\hline
\end{tabular}

${ }^{1}$ Of Bird Spring Formation in map area.

\section{Monte Cristo Limestone}

Rocks herein assigned to the Monte Cristo Limestone of Mississippian age (fig. 2 ) are well exposed along the line of measured section SM2 and at fossil locality 1 (fig. 3), but elsewhere they are mostly covered by colluvium. These rocks, $52 \mathrm{~m}$ thick with the base covered, consist primarily of massive, mostly light-colored limestone and marble (fig. 8A), which closely resemble rocks of the Bullion Member of the Monte Cristo Limestone in the Providence Mountains (Hazzard, 1954) and elsewhere in the Mojave Desert region (Brown, 1991). Colonial corals (fig. 8B) that we identify as Diphyphyllum aff. D. lateseptatum McCoy at fossil locality 1 (appendix 2; table 1) suggest a Middle Mississippian (Visean) age, and poorly preserved corals consistent with a Mississippian age are present at fossil locality 2 (fig. 4). The presence of corals in massive limestone suggests a shallow-water marine environment of deposition.

In the Providence Mountains, the Bullion Member of the Monte Cristo Limestone is overlain by dark-gray limestone that Hazzard (1954) assigned to the Yellowpine Member. Because an equivalent dark-gray limestone unit does not appear to be present in the Ship Mountains, we consider the entire exposed section of the Monte Cristo Limestone to represent the Bullion Member.

\section{Bird Spring Formation}

\section{Lithology and Thickness}

Rocks herein assigned to the Bird Spring Formation consist of variably metamorphosed limestone, dolomite, silty to sandy limestone and dolomite, and calcareous sandstone. The maximum exposed stratigraphic thickness of these rocks is about $900 \mathrm{~m}$, which includes about $180 \mathrm{~m}$ (member 1) northeast of the fault on hill 1 and about $720 \mathrm{~m}$ of younger strata (members 2-5) southwest of the fault (igs. $4, \underline{6}$ ). No stratigraphic overlap is recognized between members 1 and 2 across the fault, meaning that an unknown thickness of strata may be missing due to alluvial cover between the top of member 1 and the base of member 2 .

\section{Member 1}

Rocks assigned to member 1 of the Bird Spring Formation overlie the Monte Cristo Limestone northeast of the fault on hill 1 (figs. 4, 7A). These rocks consist of thick-bedded to massive, mostly light-colored limestone, marble, and dolomite, with scattered beds of brown-weathering, silty to sandy limestone and dolomite generally less than $3 \mathrm{~m}$ thick (pl. 1; fig. 6). Member 1 is 183 m thick at measured section SM2 with the depositional top not exposed because of faulting and alluvial cover. 


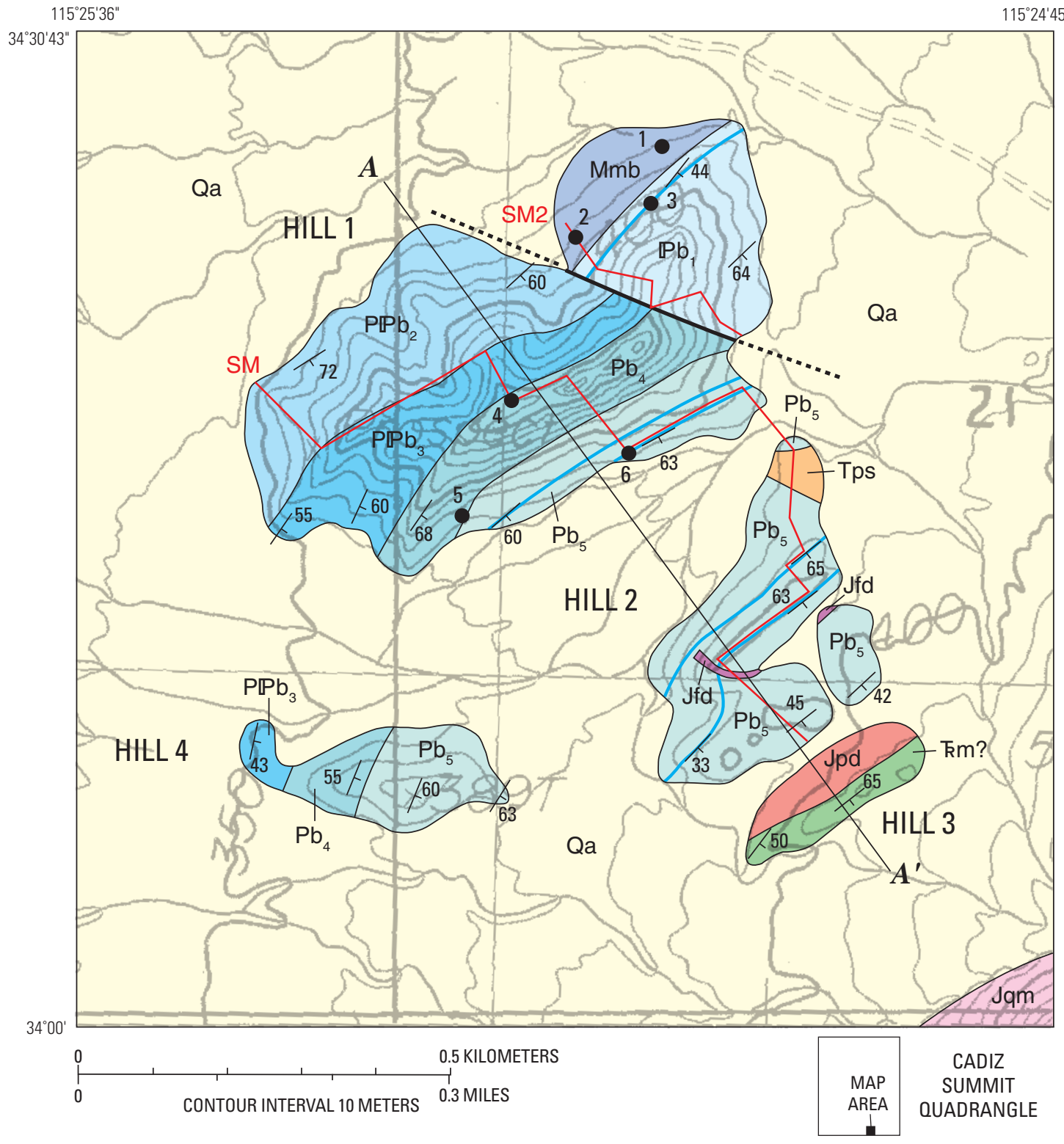

A

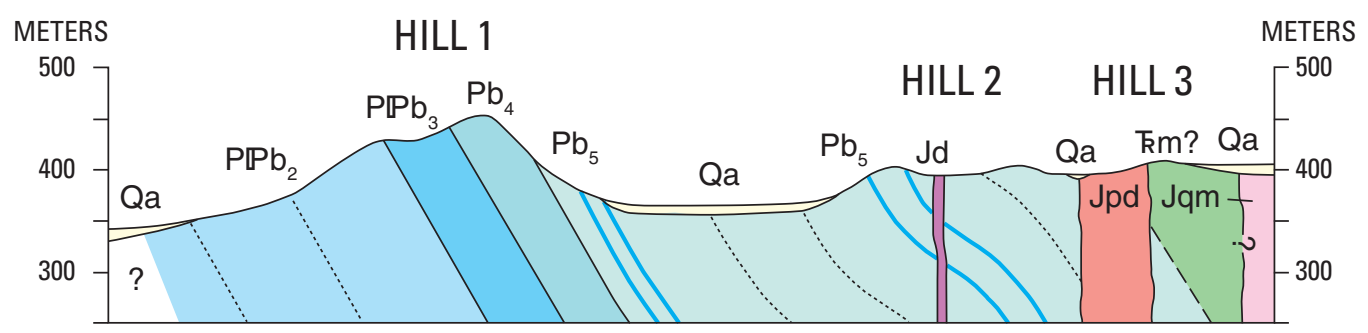

Figure 4. Geologic map and cross section of upper Paleozoic and associated rocks on the west side of the Ship Mountains. Geology mapped by Paul Stone and C.H. Stevens (this study) in 2003 and 2010. 


\section{EXPLANATION}

Qa Alluvium (Quaternary) - Unconsolidated to weakly consolidated gravel and sand

Tps Peach Spring Tuff (Miocene)_Light-gray, brown-weathering welded tuff containing scattered phenocrysts (mainly sanidine and plagioclase) and minor lithic clasts

Jfd Fine-grained diorite dike (Jurassic?)—Dark-gray rock composed of fine-grained plagioclase and mafic minerals

Jpd Altered porphyritic diorite dike (Jurassic?)-Light-greenish-gray to medium-dark-gray rock composed of 40 percent sausseritized plagioclase phenocrysts 1-5 mm across in a fine-grained groundmass of altered plagioclase and mafic minerals

Jqm Porphyritic quartz monzonite (Jurassic) -Pinkish-gray potassium feldspar phenocrysts 1-2 cm across in a medium-grained groundmass of plagioclase, quartz, and mafic minerals (color index 15-20). Part of granite of Ship Mountains of Howard (2002)

Km? Moenkopi Formation (Triassic)?-Brown-weathering, fine- to medium-grained calcareous sandstone. Exposed thickness about $25 \mathrm{~m}$

\section{Bird Spring Formation (Permian and Pennsylvanian)}

$\mathrm{Pb}_{5}$

$\mathrm{Pb}_{4}$

$\mathrm{PPb}_{3}$

$\mathrm{PPb}_{2}$

$\mathrm{Pb}_{1}$

$\mathrm{Mmb}$

Bullion Member of Monte Cristo Limestone (Mississippian)—Massive light-gray limestone and marble

Contact

Fault_-Dotted where concealed

Prominent limestone bed or zone

68

Strike and dip of beds

3

Fossil locality

SM2

Member 5 (Permian)_-Thin- to thick-bedded dolomite, limestone, dolomitic limestone, silty to sandy limestone, and quartzose sandstone. Minor fossiliferous limestone. Fusulinids present in lower part of unit. Partly covered by alluvium and tuff. Thickness about $385 \mathrm{~m}$

Member 4 (Permian)—Thick-bedded to massive, fossiliferous gray limestone with nodular chert. Fusulinids abundant throughout unit. Thickness about $55 \mathrm{~m}$

Member 3 (Permian and/or Pennsylvanian)_-Upper and lower subunits of brown-weathering sandy limestone, calcareous sandstone, and quartzite; middle subunit of massive, white to light-gray limestone. Thickness about $80 \mathrm{~m}$

Member 2 (Permian and/or Pennsylvanian)_-Thick-bedded to massive limestone and dolomite. Thickness about $140 \mathrm{~m}$

Member 1 (Pennsylvanian)—Thick-bedded to massive limestone and dolomite; minor silty limestone and fossiliferous limestone. Basal $2 \mathrm{~m}$ consists of dark-gray limestone containing phosphatic clasts. Thickness about $180 \mathrm{~m}$

Line of measured section

Figure 4.-Continued 

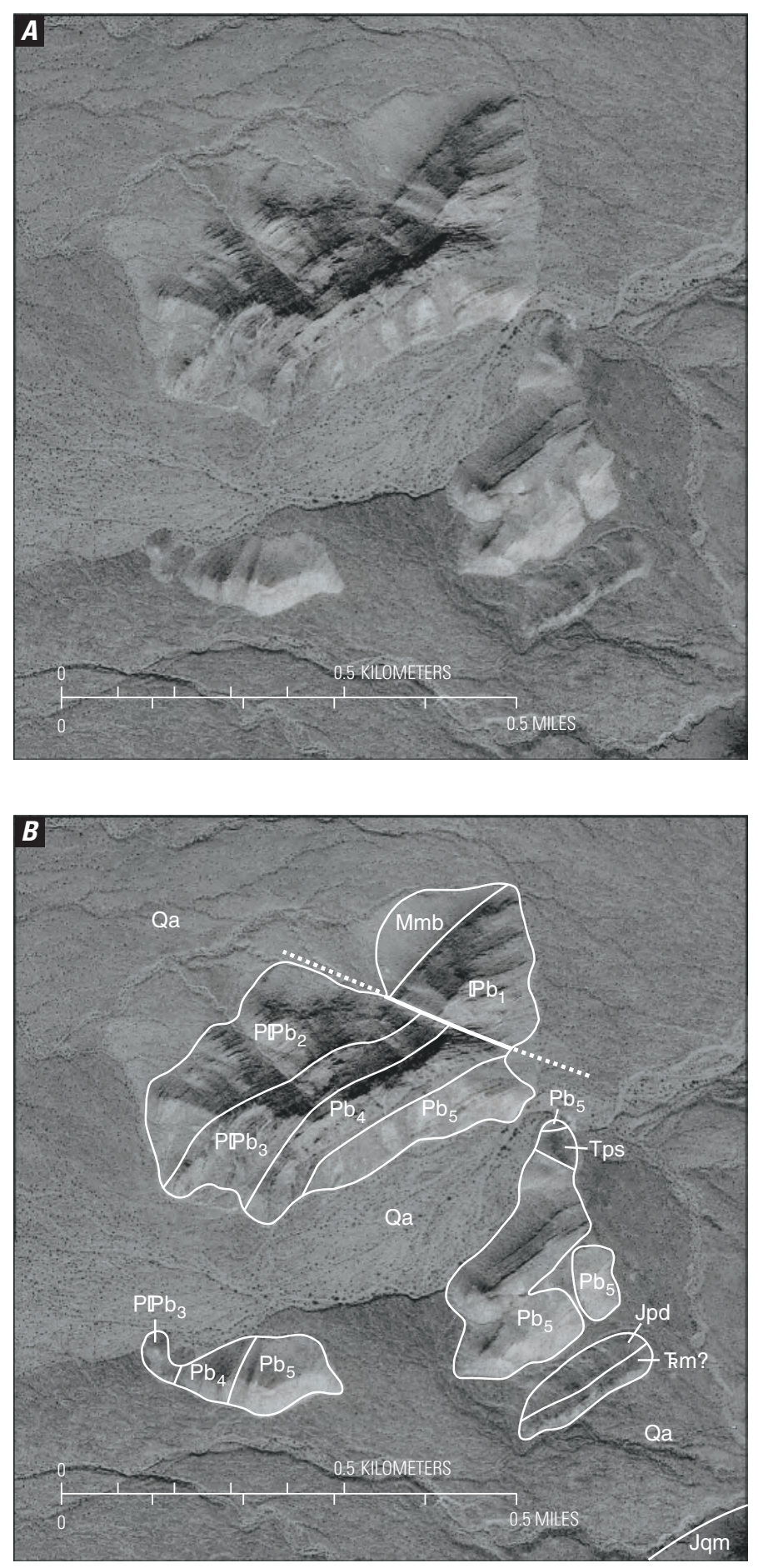

Figure 5. A, Digital orthophoto (rectified aerial photograph) of map area shown in figure 4. $B$, Simplified geology on orthophoto base. Geologic lines and symbols are the same as in figure 4.
The basal 0.5 to $2 \mathrm{~m}$ of member 1 consists of dark-gray limestone (fig. 8C) characterized by dark-colored, poorly sorted, sand- to pebble-size clasts supported by a fine-grained matrix. Petrographic examination and x-ray diffraction analysis (appendix 3; samples SM2-1, 10-SM-04) show that many of the sand-size clasts are phosphatized crinoid stems and that the larger clasts are aggregates of phosphatized crinoid stems and peloids together with recrystallized calcite. This basal phosphatic limestone sharply overlies the Bullion Member of the Monte Cristo Limestone. In measured section SM2, the basal limestone is overlain by $17 \mathrm{~m}$ of massive, ledge-forming dolomite, which in turn is overlain by $4 \mathrm{~m}$ of silty limestone, and then by a 1.5-m-thick bed of dark-gray, locally fossiliferous limestone. Mapping (fig. 4) shows that this dark-gray limestone bed is continuous across the outcrop area of member 1 . Brachiopods and other fossils are locally visible in this bed.

The dark-gray limestone bed is succeeded by approximately $80 \mathrm{~m}$ of buff dolomite interbedded with several thin layers of brown-weathering silty dolomite and a prominent zone of silty limestone 2 to $3 \mathrm{~m}$ thick (fig. 7D). Above this dolomitic sequence, the remaining strata exposed in member 1 , approximately $80 \mathrm{~m}$ thick, consist primarily of light-gray limestone and marble, with minor interbedded buff dolomite. The upper part of member 1 crops out on the southeast side of hill 1 where it is in fault contact with limestone of member 4 (fig. 7F).

\section{Member 2}

Rocks assigned to member 2 of the Bird Spring Formation have a maximum exposed thickness of about $200 \mathrm{~m}$ with the base covered (see cross section $A-A^{\prime}$, fig. 4). About $142 \mathrm{~m}$ of member 2 is traversed by measured section SM (pl. 1; fig. 6), the base of which is stratigraphically higher than the lowest rocks exposed in the area of maximum thickness.

Member 2 is primarily composed of light-colored, thick-bedded to massive limestone, marble, and dolomite. Bedding typically is indistinct (fig. 7C). The lower half of the member is primarily dolomite in which brown-weathering chert bands are present locally. Some dolomite beds contain millimeter-scale, planar to wavy lamination of possible algal origin. The upper half of member 2 is primarily limestone and marble, with scattered layers of chert and and calc-silicate rocks. Other than local faint lamination, most of these rocks lack obvious sedimentary structures. Petrographic examination of limestone and dolomite samples from member 2 appendix 3) shows varying degrees of recrystallization, with little if any preservation of the original sedimentary texture.

Member 2 is lithologically similar to member 1 although the latter contains more terrigenous detritus. As previously noted, we do not recognize any stratigraphic overlap between members 1 and 2, although more careful study of the lowermost rocks of member 2 (below the level of measured section SM) would be necessary to rule out the possibility of such an overlap. 


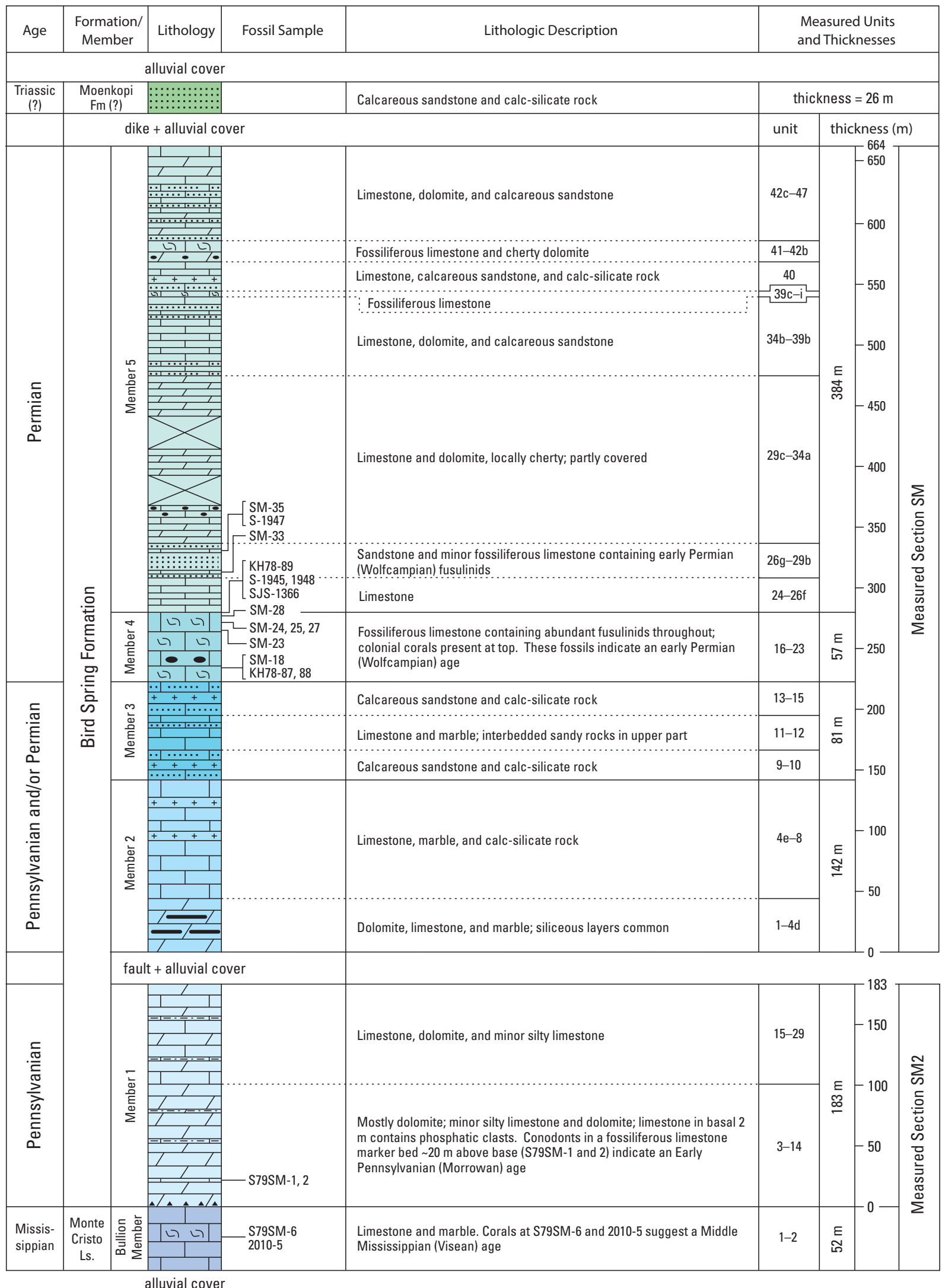

Figure 6. Generalized stratigraphic column of upper Paleozoic and Triassic(?) rocks in the Ship Mountains based primarily on measured sections SM and SM2 (appendix 1; pl. 1). Lower Triassic Moenkopi Formation(?) was measured separately. Fossil samples SM18-35 are from measured section SM (table 2); stratigraphic positions of other fossil samples (table 1) are inferred from map locations (fig. 4). Units (for example, 42c-47) refer to measured intervals in sections SM and SM2 (appendix 1). See plate 1 for explanation of symbols. 

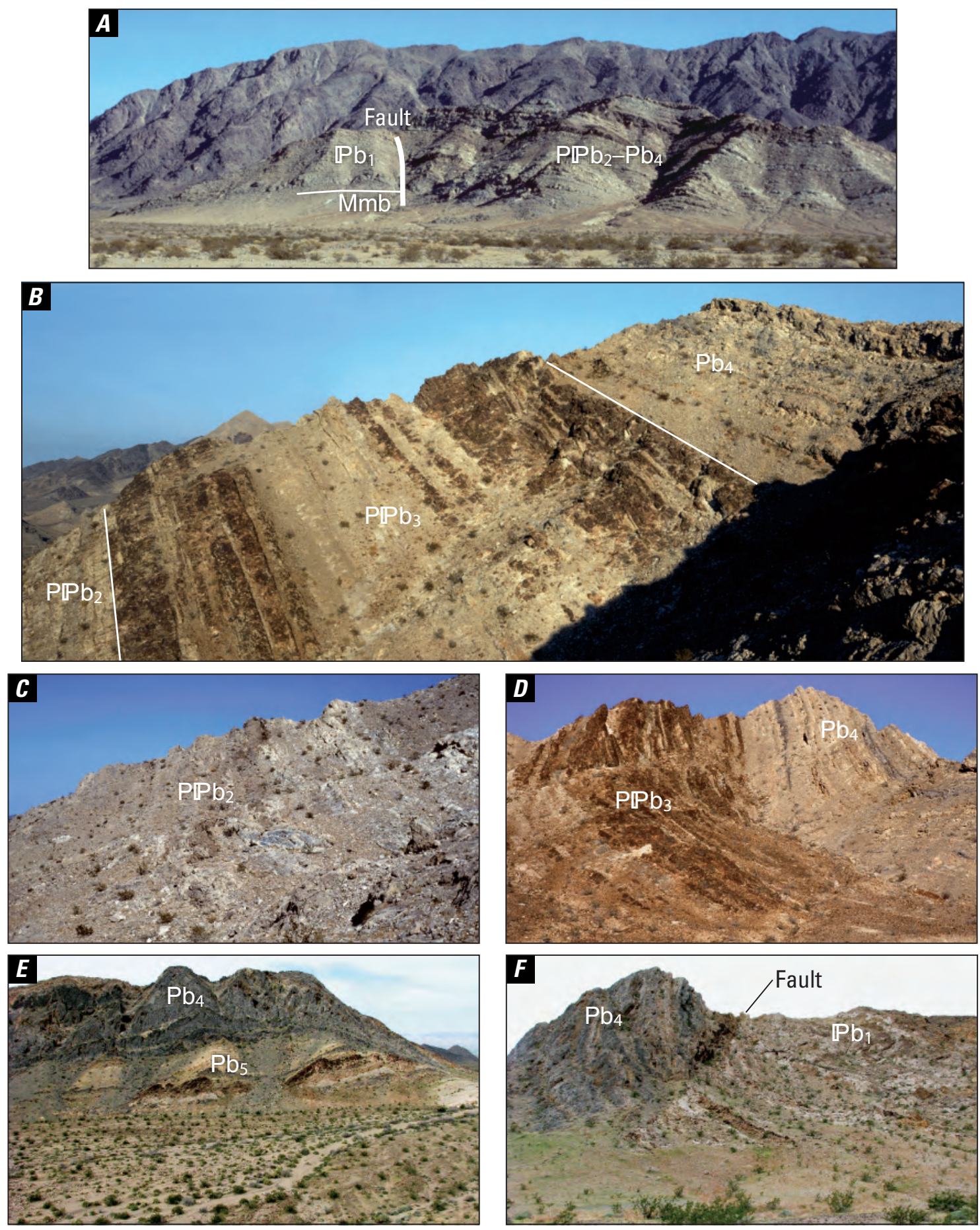

Figure 7. Annotated field photographs of upper Paleozoic rocks in the Ship Mountains. A, View west to hill 1 showing fault that separates Bullion Member of the Monte Cristo Limestone $(\mathrm{Mmb})$ and member 1 of the Bird Spring Formation $\left(\mathbb{P b}_{1}\right)$ from members 2-4 of the Bird Spring Formation $\left(\mathrm{PPb}_{2}-\mathrm{Pb}_{4}\right)$. Dark weathering granitoid rocks form high ridge of Ship Mountains in background. $B$, View northeast along northwest side of hill 1, showing two characteristic dark-brown sandy units that make up the lower and upper parts of member 3 of the Bird Spring Formation ( $\left.\mathrm{PPb}_{3}\right)$; middle part of member 3 is composed of limestone and minor sandy rocks. Member 3 overlies limestone of member $2\left(\mathrm{PPb}_{2}\right)$ and is overlain by fusulinid-bearing limestone of member $4\left(\mathrm{~Pb}_{4}\right)$. C, Typical thick-bedded to massive limestone and dolomite in member 2 of the Bird Spring Formation $\left(\mathrm{PPb}_{2}\right)$, hill 1. D, View northeast to summit of hill 1, showing brown-weathering sandy rocks of member 3 of the Bird Spring Formation $\left(\mathrm{PPb}_{3}\right)$ overlain by light-colored limestone of member $4\left(\mathrm{~Pb}_{4}\right)$. $E$, View northwest to the southeast side of hill 1, showing recessive strata of member 5 of the Bird Spring Formation $\left(\mathrm{Pb}_{5}\right)$ in sharp depositional contact above resistant limestone of member $4\left(\mathrm{~Pb}_{4}\right)$. Beds dip steeply toward viewer. $F$, View northwest to southeast side of hill 1, showing fault between members 1 and $4\left(\mathrm{~Pb}_{1}, \mathrm{~Pb}_{4}\right)$ of the Bird Spring Formation. 

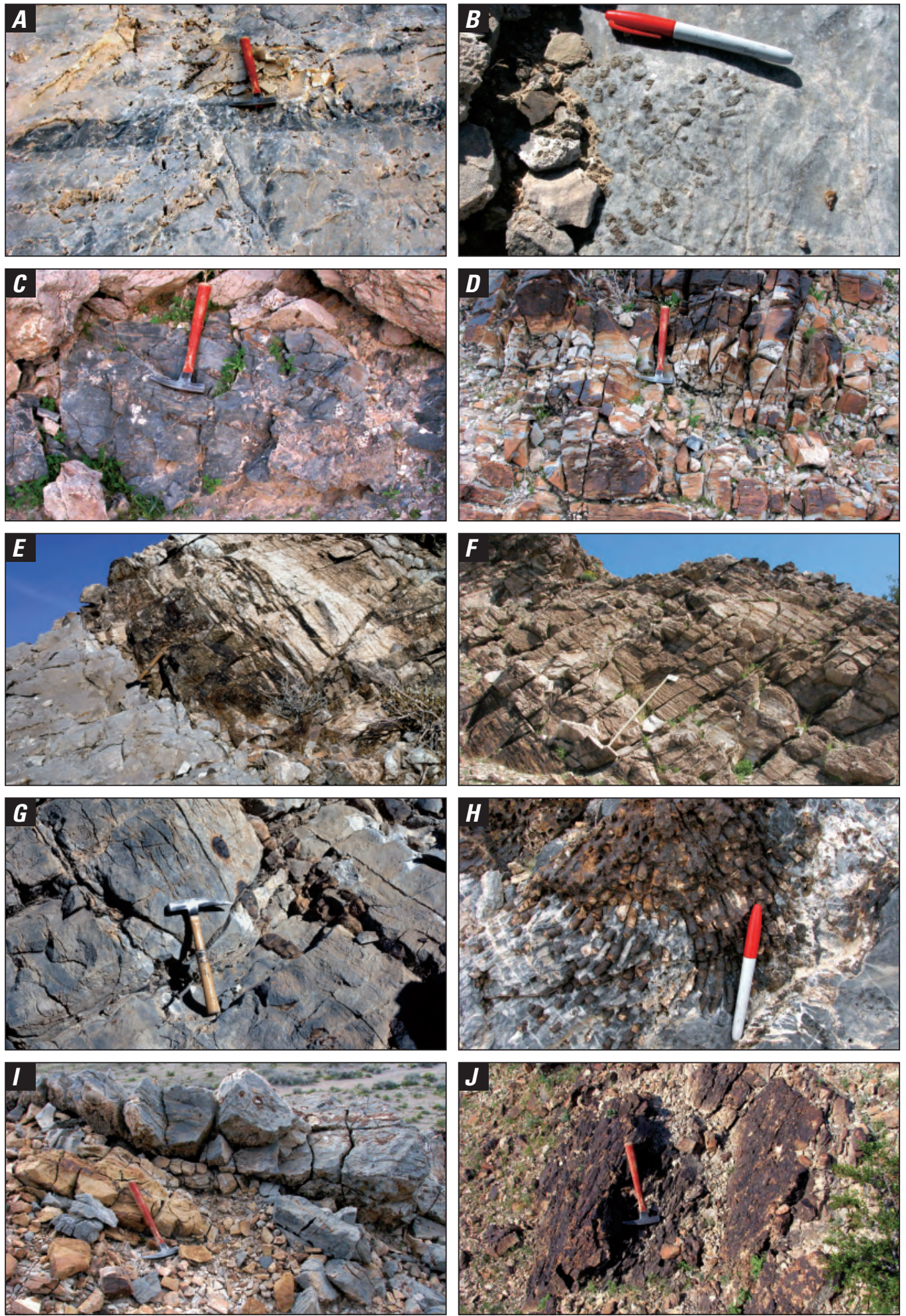

Figure 8. Outcrop photographs of upper Paleozoic and Triassic(?) rocks in the Ship Mountains. A, Massive marble of Bullion Member of the Monte Cristo Limestone. B, Colonial coral Diphyphyllum aff. D. lateseptatum McCoy in Bullion Member of the Monte Cristo Limestone, fossil locality 1 (fig. 4). C, Dark phosphatic limestone at base of Bird Spring Formation. D, Silty limestone in member 1 of the Bird Spring Formation. E, Dark-brown calcareous sandstone and white calc-silicate rocks at base of member 3 of the Bird Spring Formation, above gray limestone at top of member 2. F, Laminated calcareous sandstone in member 3 of the Bird Spring Formation. G, Thick-bedded limestone with scattered chert nodules in member 4 of the Bird Spring Formation. H, Colonial coral Tschussovskenia connorsensis (Easton) at top of member 4 of the Bird Spring Formation, fossil locality 5 (fig. 4). I, Light-brown sandstone overlain by bioclastic limestone in the lower part of member 5 of the Bird Spring Formation. J, Typical outcrop of sandstone in the Lower Triassic Moenkopi Formation(?). 

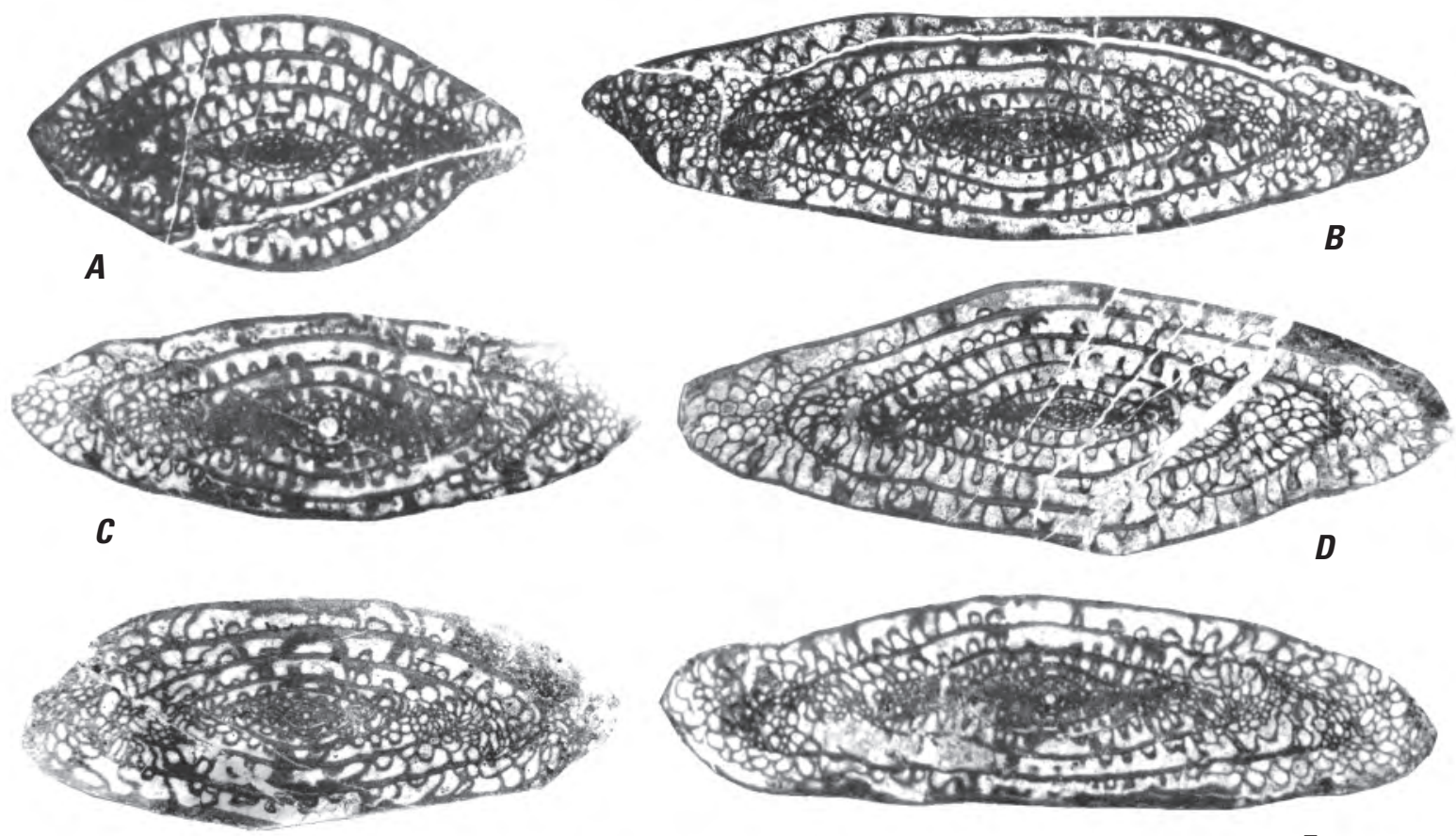

$\boldsymbol{E}$

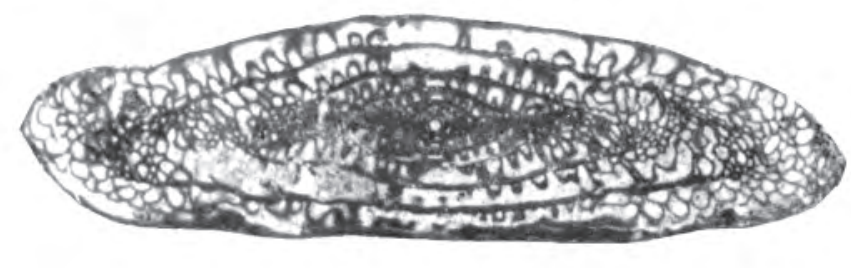

$\boldsymbol{F}$
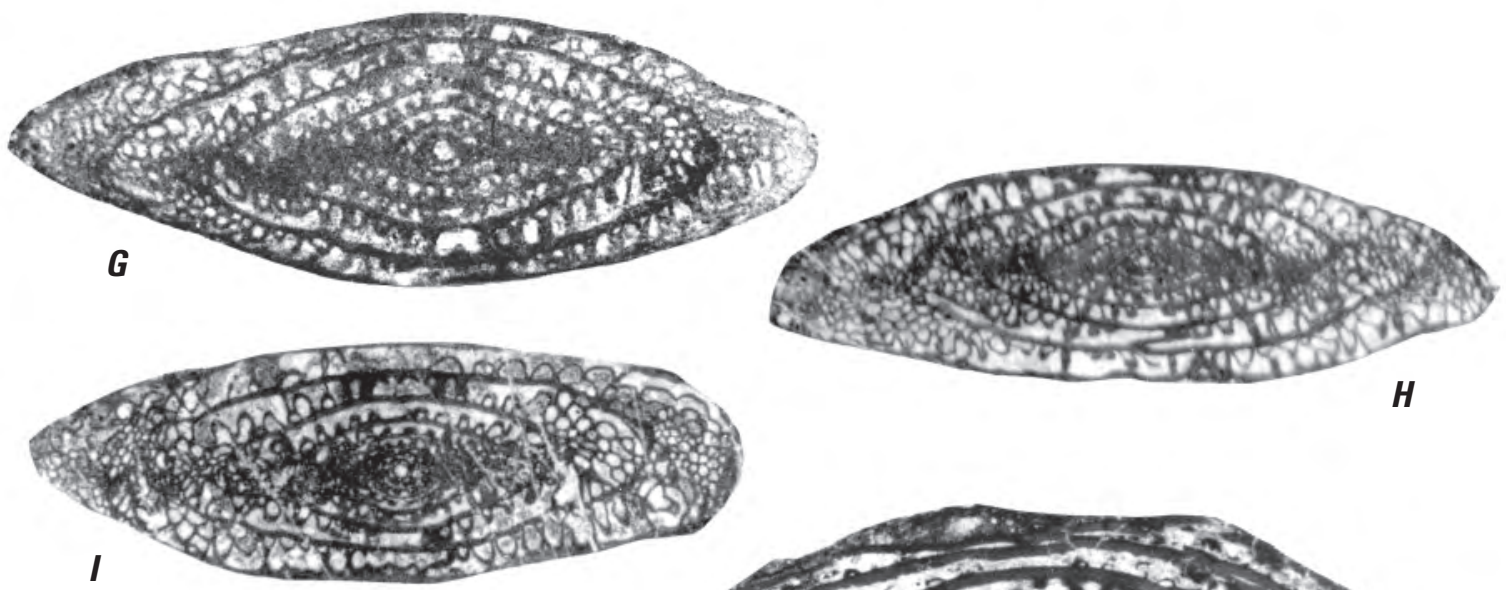

H
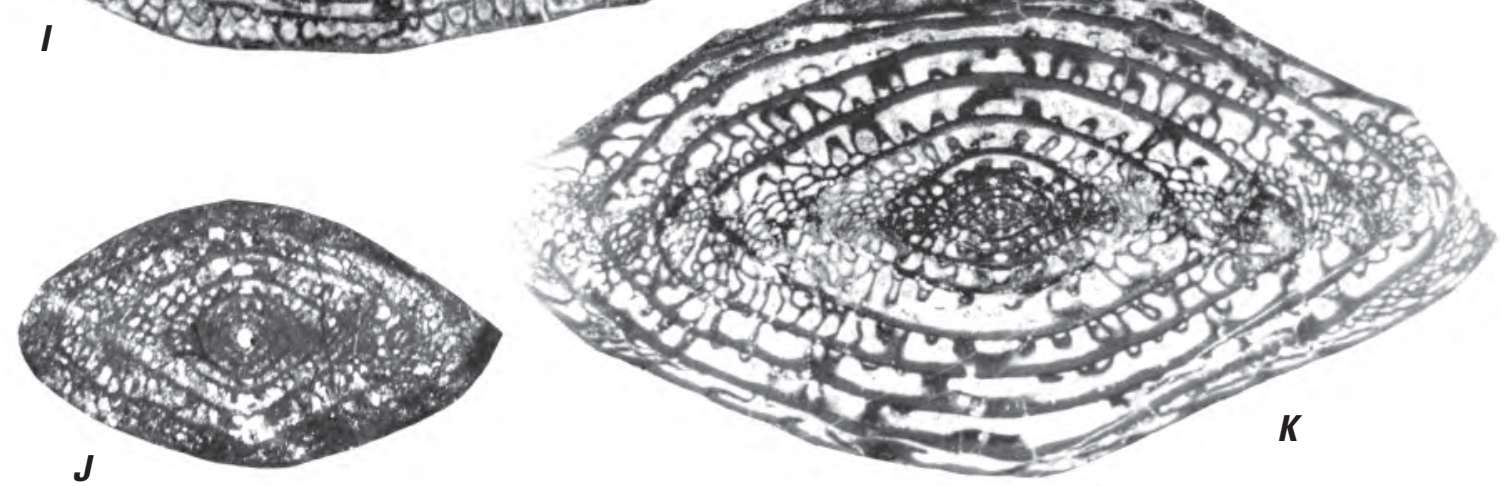

Figure 9. Fusulinids from the Bird Spring Formation in the Ship Mountains (see fig. 4 and tables 1 and $\underline{2}$ for fossil localities and sample numbers). All figures are axial sections, $\times 8.5$. A, Schwagerina aculeata Thompson and Hazzard; SJS 168f, sample S-1945, fossil locality 5. B, Schwagerina cf. S. pugunculus Ross; SJS 180f, sample S-1945, fossil locality 5. C, G, Schwagerina cf. S. wellsensis Thompson and Hansen; both from measured section SM; C, sample SM-27 (USGS f14067); G, sample SM-35 (USGS f14070). D, Paraschwagerina elongata Skinner and Wilde; SJS186f, sample S-1945, fossil locality 5. E, Stewartina sp. 1 of Stevens and Stone (2007); sample KH78-89 (USGS f14073), fossil locality 5. F, H, I, Schwagerina providens Thompson and Hazzard; all from measured section SM, sample SM-27 (USGS f14067). J, Schwagerina sp. 3 of Stevens and Stone (2007); SJS 169f, sample S-1947, fossil locality 6. K, Stewartina multispira (Thompson and Hazzard); measured section SM, sample SM-27 (USGS f14067). All specimens except $H$ and / were previously illustrated by Stevens and Stone (2007). 

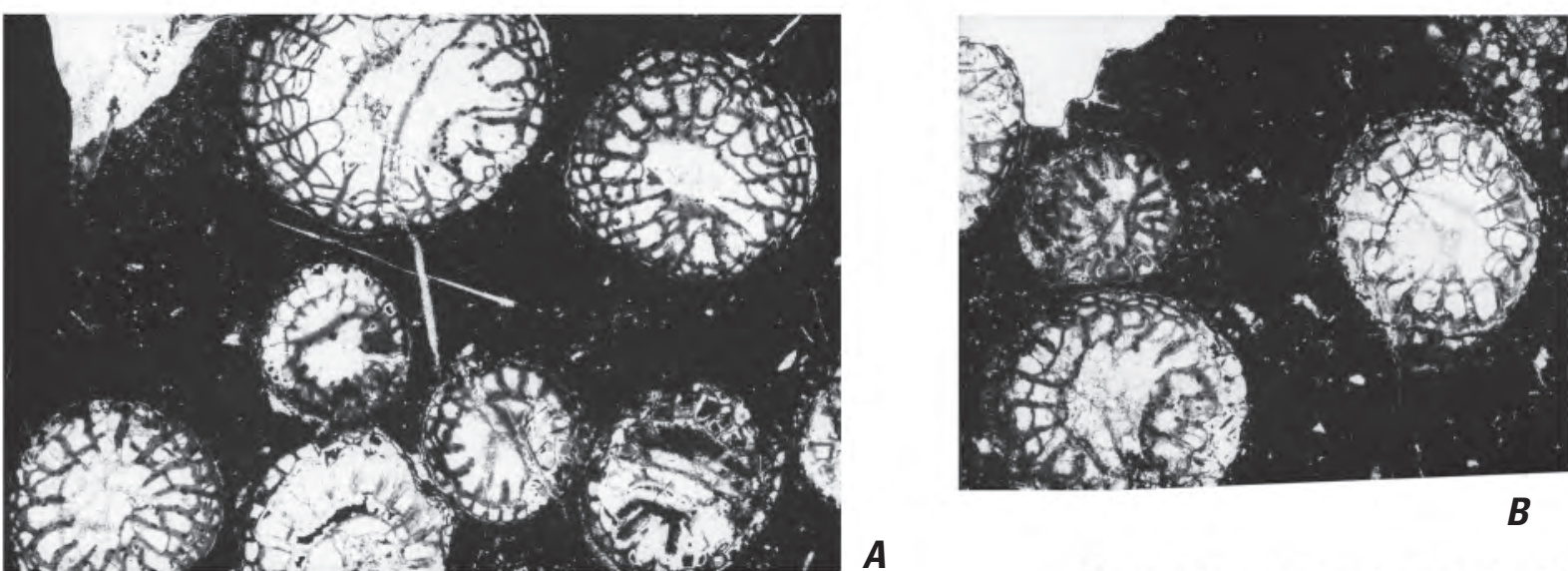

A
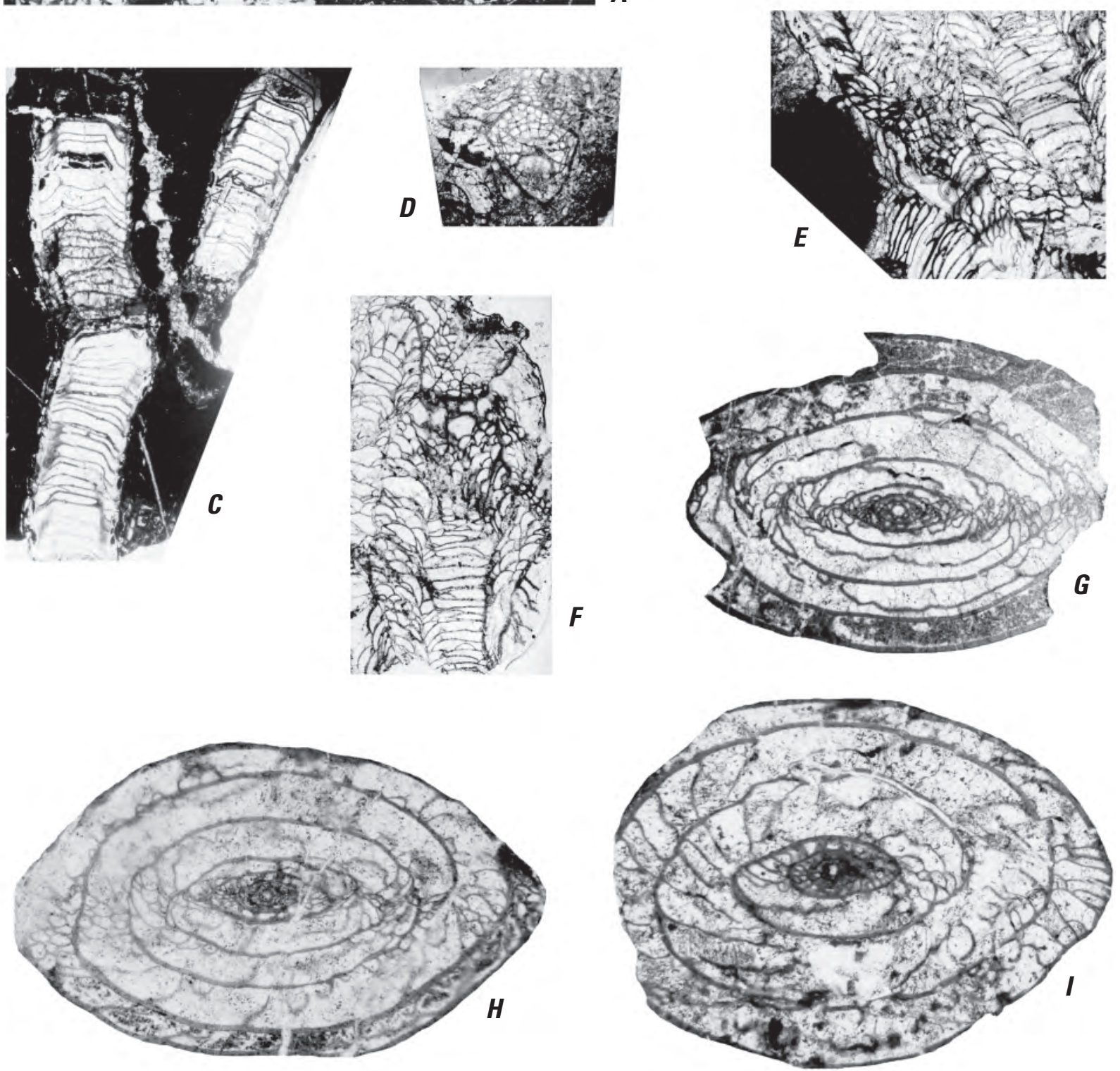

Figure 10. Corals $(A-F)$ and fusulinids $(G-l)$ from the Bird Spring Formation in the Ship Mountains. All specimens are from fossil locality 5 (fig. 4, table 1). A-C, Tschussovskenia connorsensis (Easton); $A$, B, SJS 348c and 349c, respectively, transverse sections, $\times 2.7$; C, SJS 350c, longitudinal section, $\times 1.8$; all from sample SJS-1366. D, E, F, Protowentzelella kunthi (Stuckenberg); D, SJS 351c, transverse section; E, F, SJS 352c and 353c, respectively, longitudinal sections; all $\times 2.7$; all from sample SJS-1366. G, H, I, Pseudoschwagerina arta Thompson and Hazzard; SJS 429f, 430f, 431f, respectively, axial sections, $\times 9$; all from sample S-1948. 


\section{Member 3}

Member 2 of the Bird Spring Formation is sharply overlain by brown-weathering calcareous sandstone, sandy limestone, and calc-silicate rocks that mark the base of member 3 (fig. 8E). This member, $81 \mathrm{~m}$ thick in measured section SM (pl. 1; fig. 6), has a distinctive internal stratigraphy consisting of a lower brown-weathering sandy unit ( $24 \mathrm{~m}$ ), a middle unit of lightcolored limestone and marble with minor brown-weathering sandy rocks (29 $\mathrm{m}$ ), and an upper brown-weathering sandy unit (28 m). These units form distinctive outcrop bands on the northwestern slopes of hill 1 (ig. $7 B$ ).

The brown-weathering sandy and calc-silicate rocks of member 3 are mostly thick-bedded and typically form resistant ledges. Plane lamination (fig. 8F) and cross lamination are well developed. Some beds show interbedded layers of relatively pure limestone or marble and brown siliceous rock. Thin sections of the brown-weathering rocks show variations from relatively unmetamorphosed sandy limestone or calcareous sandstone to thoroughly metamorphosed calc-silicate rock (appendix 3). Most samples contain 40 to 60 percent finegrained, well-sorted quartz and minor feldspar sand in a matrix of crystalline calcite, calc-silicate minerals, or both.

Thick-bedded to massive, variably recrystallized limestone and marble that form the middle part of member 3 are lithologically similar to rocks in the upper part of member 2. The presence of minor brown-weathering sandy rocks in the upper part of this calcareous unit (fig. 7B) indicates a gradational contact with the upper brown unit.

\section{Member 4}

A sharp contact (igs. 7B, $\underline{D})$ separates brown-weathering sandy rocks at the top of member 3 from the overlying limestone sequence herein assigned to member 4 . This member, $57 \mathrm{~m}$ thick in measured section SM (pl. 1; fig. 6), is composed of resistant limestone that forms the rugged crest of hill 1 (fig. 7D), with the uppermost beds forming steep dip slopes on the southeast side of that hill. Less spectacular exposures of member 4 are present on hill 4 .

Member 4 is composed of light- to dark-gray, thick-bedded to massive limestone characterized by an abundance of bioclastic material and local occurrences of nodular chert (fig. 8G). Echinodermal debris and fusulinids are present throughout the member, brachiopods are present in a few beds, and large colonial corals (fig. $8 H$ ) are locally present at or near the top (for example, fossil locality 5, fig. 4). Member 4 contains no significant dolomite or terrigenous detritus.

Field and petrographic observations (appendix 3 ) show that most rocks in member 4 are biomicritic limestones that range in texture from mudstone (less than 10 percent bioclasts) to wackestone (more than 10 percent bioclasts but still matrix-supported) to packstone (clast-supported with a micrite matrix). Besides echinoderm debris and fusulinids, common bioclasts include small foraminifera and shell fragments. Some bioclasts are silicified, and others are micritized or recrystallized. Fusulinid chambers are typically filled with sparry calcite in contrast to the micritic matrix of the rock. A few thin sections contain rare quartz silt or sand.

\section{Member 5}

Generally light colored, recessive limestone, dolomite, and sandstone that form the upper $384 \mathrm{~m}$ of measured section SM are herein assigned to member 5 of the Bird Spring Formation (pl. 1; $\underline{\text { fig. } 6}$ ). Rocks at the base of this unit sharply overlie the uppermost resistant limestones of member 4 on the southeast side of hill 1 , creating a prominent lithologic contact and topographic break (fig. 7E). Part of member 5 is covered by Quaternary alluvium between hills 1 and 2, and the top of member 5 also is covered by alluvium.

Most rocks in member 5 are light-gray to grayish-orange, fine-grained limestone and dolomite that form topographically subdued outcrops. Bedding ranges from indistinct to well defined; beds 15 to $30 \mathrm{~cm}$ thick are typical. Lamination, nodular texture, and chert nodules are present locally in these otherwise relatively featureless rocks. Thin sections (appendix 3) show a typical composition of very fine grained calcite or dolomite with scattered iron oxide impurities. A few samples contain small amounts (1-2 percent) of quartz silt. Bioclastic material is conspicuously absent in these rocks.

About 10 percent of member 5 is composed of fine-grained sandstone, calcareous sandstone, and quartzite that are interbedded with the dominant carbonate rocks. These commonly brown-weathering, plane-laminated rocks form layers that range from less than $1 \mathrm{~m}$ to about $10 \mathrm{~m}$ thick. Petrographic examination (appendix 3) shows that these rocks typically are composed of 25 to 75 percent finegrained quartz and minor feldspar sand, 25 to 50 percent calcite, and as much as 25 percent calc-silicate minerals. The calcite includes sand-size grains of probable detrital origin as well as interlocking crystals that could have formed by recrystallization of detrital grains or as sparry cement. Alternating laminae with different proportions of quartz and calcite are present in some samples. One sample (SM-54) near the top of member 5 has conspicuous heavy-mineral laminae that contain concentrations of detrital zircon and iron oxide grains.

Four relatively resistant, laterally continuous beds or zones of bioclastic limestone stand out above the enclosing nonresistant rocks of member 5 (pl. 1; figs. $4, \underline{6}$ ). The lower two of these are single beds of bioclastic limestone, each about a meter thick, 32 and $51 \mathrm{~m}$ above the base of member 5 on hill 1 (pl. 1, appendix 1, measured section SM, units 26j and 28c). Both of these very similar beds contain abundant fusulinids and both are directly overlain and underlain by brown-weathering calcareous sandstone or sandy limestone (fig. 8I). The higher two are zones of limestone beds, about 5 and $15 \mathrm{~m}$ thick with bases about 261 and $292 \mathrm{~m}$ above the base of member 5, respectively (pl. 1, appendix 1, measured section SM, units 39c-i and 41-42b). Fossils in these zones include brachiopods and echinoid spines. 


\section{Fossils and Age}

Biostratigraphic studies of several fossil groups, primarily fusulinids, other foraminifera, and conodonts (for example, Rich, 1961; Cassity and Langenheim, 1966; Richards and others, 2002; Stevens and Stone, 2007), have established a regional age range of latest Mississippian (late Chesterian) to early Permian (Leonardian) for the Bird Spring Formation (fig. 2; Langenheim and Larson, 1973), although the oldest strata assigned to this formation in most places are thought to be of early Pennsylvanian (Morrowan) age. We here assign the Bird Spring Formation in the Ship Mountains a Pennsylvanian to early Permian age based on fossil evidence from the study area (summarized below) and general lithostratigraphic correlation with the Bird Spring Formation in the nearby Providence Mountains, where Pennsylvanian and early Permian fossils are well documented (Thompson and Hazzard, 1946; Hazzard, 1954; Stevens and Stone, 2007) and where Law (1969) identified Early Pennsylvanian (Morrowan) conodonts as low as $2 \mathrm{~m}$ above the base of the formation.

In the Ship Mountains, age-diagnostic fossils have been identified from a single bed in the lower part of member 1 , from several beds in member 4 , and from two beds in the lower part of member 5 of the Bird Spring Formation (pl. 1; fig. 6; tables 1, 2; appendix 2). These fossils are consistent with an age range of Early Pennsylvanian (Morrowan) to early Permian (Wolfcampian) but do not provide a basis for detailed age interpretations for most parts of the formation.

Several types of fossils were recovered from the dark-gray limestone bed about $20 \mathrm{~m}$ above the base of member 1 at fossil locality 3 (fig. 4; table 1). Most significantly, samples from this locality yielded conodonts that indicate an Early Pennsylvanian (Morrowan) age (John Repetski, written commun., 1980). Ostracodes, bryozoans, and brachiopods, all compatible with an Early Pennsylvanian age, also have been identified (appendix 2).

Fusulinids have been identified in several samples from member 4 and the lower part of member 5 (pl. 1; fig. 6). The fusulinid fauna includes species of Schwagerina, Stewartina, and Pseudoschwagerina (figs. 9, 10) that indicate an early Permian (Wolfcampian) age (tables 1, 2). More specifically, the fauna is typical of fusulinid zone 3 of Stevens and Stone (2007), the age of which is interpreted as latest Asselian to middle Sakmarian (late early to middle middle Wolfcampian; fig. 2). The colonial corals Tschussovskenia connorsensis (Easton) and Protowentzelella kunthi (Stuckenberg) from the top of member 4 (fig. 10) are compatible with this age interpretation.

Apart from the fossiliferous strata noted above, the ages of most parts of the Bird Spring Formation in the Ship Mountains must be inferred. Given its modest exposed thickness of less than $200 \mathrm{~m}$, and the Morrowan age of fossils in its lower part, it seems likely that member 1 is entirely of Pennsylvanian age. Members 2 and 3, on the other hand, could be either Pennsylvanian or Permian in age. Member 3, in particular, probably is at least in part Permian, because rocks of earliest Permian age are not represented in the apparently conformably overlying member 4 . Rocks of member 5 above the highest fusulinid bed (fig. 6, sample SM-35) are inferred to be of early Permian age based on regional stratigraphic relations (Langenheim and Larson, 1973).

\section{Basal Disconformity}

Although concordant, the basal contact of the Bird Spring Formation with the underlying Monte Cristo Limestone in the Ship Mountains is almost certainly disconformable. Regional biostratigraphic studies show that the youngest rocks of the Monte Cristo Limestone (either the Bullion Member or the overlying Yellowpine Member) and correlative units are no younger than Middle Mississippian (middle Meramecian) in age (Langenheim and Larson, 1973; Stevens and others, 1996; fig. 2). Thus, stratigraphic sections in which Morrowan rocks of the Bird Spring Formation directly overlie the Monte Cristo Limestone omit rocks of latest Mississippian (late Meramecian and Chesterian) age, which are thought to represent a time interval of more than 15 m.y. (Davydov and others, 2004). Rocks of Late Mississippian age (assigned to the Indian Springs and Battleship Wash Formations) are present in parts of southern Nevada and adjacent California, but are absent in the Providence Mountains (Hazzard, 1954) and areas to the southeast (Stone and others, 1983; Brown, 1991).

\section{Depositional Environments}

We interpret strata of the Bird Spring Formation in the Ship Mountains study area to have originated as shallow-water marine shelf deposits. This interpretation is consistent with the predominance of carbonate rocks in the formation, the local presence of shallow-water marine fossils such as fusulinids and corals, and the lack of any evidence of deep-water pelagic, hemipelagic, or turbiditic deposition. The significant amount of quartzose sandstone in the formation, particularly member 3 , suggests that the study area lay near the interface between areas of predominantly carbonate and siliciclastic sedimentation.

Thick-bedded to massive limestone and dolomite that make up most of members 1 and 2 of the Bird Spring Formation represent carbonate-platform deposition, although detailed environmental interpretations are precluded by extensive recrystallization that has obscured the original sedimentary textures of these rocks. The large proportion of dolomite in member 1 and the lower part of member 2 suggests a very shallow water, restricted shelf environment of deposition. The local presence of marine fossils in the limestone marker bed about $20 \mathrm{~m}$ above the base of member 1 (fossil locality 3 , fig. 4) points to more open marine conditions for at least this small part of the stratigraphic sequence.

Phosphatic clasts (including phosphatized bioclasts) in the thin basal limestone of member 1 presumably formed by early diagenetic replacement of calcium carbonate in an environment rich in organic matter, a major source 
of phosphorus in marine environments (Bentor, 1980). In general, phosphatic sediments are thought to occur preferentially at unconformities (Pettijohn, 1975) and in condensed sections representing slow rates of sedimentation (Bentor, 1980).

The sandy rocks of member 3 probably represent a shallow-water, nearshore marine environment inboard from areas of contemporaneous carbonate sedimentation. The distinguishing characteristics of these rocks, including fine grain size, good sorting, and well-developed planar and cross lamination, suggest deposition by wave-generated current activity in a shallow subtidal or intertidal setting.

The fusulinid- and coral-bearing limestones of member 4 represent open marine conditions in warm, clear, well-oxygenated water of normal marine salinity. These rocks, which are virtually free of terrigenous detritus, appear to represent a major marine transgression that reestablished the carbonate shelf. The abundance of carbonate mud (micrite) in the rocks of member 4 suggests a relatively low energy environment largely unaffected by wave or current activity.

In contrast, the overlying light-colored, unfossiliferous, fine-grained limestone and dolomite beds that make up most of member 5 are more typical of restricted shelf environments such as tidal flats (Wilson, 1975). These rocks clearly constitute a more shoreward facies than the underlying fossiliferous limestones of member 4 . This interpretation is reinforced by the thin sandstone beds that are interlayered with the carbonate rocks of member 5 . The few bioclastic limestone beds and zones in member 5 presumably reflect brief periods of more open marine conditions similar to those during deposition of member 4 .

\section{Moenkopi Formation(?)}

A 26-m-thick unit of brown-weathering calcareous sandstone and calc-silicate rock (fig. 8J) that is stratigraphically higher than member 5 of the Bird Spring Formation is herein questionably assigned to the Lower Triassic Moenkopi Formation. The base of this unit is intruded by altered dioritic dike rocks (unit Jpd) and the top is covered by alluvium (fig. 4).

In outcrop, rocks of the Moenkopi Formation(?) are mostly featureless except for bedding surfaces and vague laminae of alternating quartz sand and calc-silicate minerals. In thin section (appendix 3), most samples are fine- to medium-grained sandstone (quartz and minor feldspar grains) that contains varying proportions of interstitial calcite, calc-silicate minerals, and chert. Some samples are distinctly laminated, with laminae of fine- to medium-grained sand and interstitial calcite or calc-silicate minerals alternating with laminae of fine-grained sand and interstitial chert. Some laminae (and one entire thin section) are composed primarily of calc-silicate minerals with relatively minor quartz and calcite.
No fossils have been found in the Moenkopi Formation(?). We base our tentative unit assignment on lithologic similarity with sandstone in the lower part of the Moenkopi Formation in the Providence Mountains, where this formation disconformably overlies the Bird Spring Formation (Hazzard, 1954; Paul Stone, unpub. data, 2007). We consider this lithostratigraphic correlation stronger than the possible alternatives that the sandstone in the Ship Mountains is simply a younger, unusually terrigenous part of the Bird Spring Formation or represents an overlying Permian terrigenous unit such as the Hermit Formation or Coconino Sandstone, which are recognized in the nearby Kilbeck Hills and Little Piute Mountains (fig. 1; Stone and others, 1983). In the absence of fossils or exposed overlying strata, however, a definitive unit assignment is not possible.

The laminated sandstone of the Moenkopi Formation(?) is of generally similar sedimentological character as the thinner sandstone units in the underlying member 5 of the Bird Spring Formation and may therefore represent a similar, very shallow water marine depositional environment.

\section{Regional Stratigraphic Correlations and Paleogeographic Implications}

Upper Paleozoic and Lower Triassic(?) rocks in the Ship Mountains are part of the Cordilleran miogeocline, a westward-thickening wedge of carbonate and siliciclastic rocks representing deposition on the continental shelf of western North America from Neoproterozoic through early Mesozoic time. Regional stratigraphic and paleogeographic studies (Stewart and Poole, 1975; Stone and others, 1983) show that the miogeocline extends southwest from the Great Basin of Nevada and Utah through the Mojave Desert region of southeastern California. Stratigraphic correlations across and along the trend of the miogeocline from the Ship Mountains (fig. 11) provide insight into the paleogeographic framework of the late Paleozoic continental shelf.

Mississippian limestone like that in the Ship Mountains underlies the Bird Spring Formation and correlative units throughout most of the region under consideration (fig. 1). This limestone, which is assigned to the Monte Cristo Limestone, Rogers Spring Limestone, and Redwall Limestone in different areas (fig. 11), represents a broad carbonate shelf that extended across the region throughout most of the Mississippian (Poole and Sandberg, 1977).

Pennsylvanian and Permian strata correlative with the Bird Spring Formation in the Ship Mountains are present to the northwest and southeast across the general trend of the late Paleozoic continental margin. In the Providence Mountains, $55 \mathrm{~km}$ northwest of the Ship Mountains, about 1,500 m of strata assigned to the Bird Spring Formation (Hazzard, 1954; Stevens and Stone, 2007) are composed of a thick lower part, composed almost entirely of limestone, and a thinner upper 
part primarily composed of dolomite (fig. 11). The lower part of the Providence Mountains section can be correlated with members 1-4 of the Bird Spring Formation in the Ship Mountains based on Morrowan conodonts near the base (Law, 1969) and middle Wolfcampian fusulinids (zone 3 of Stevens and Stone, 2007) near the top. As in the Ship Mountains, the basal limestone beds in the Providence Mountains contain phosphatic clasts (Paul Stone, unpub. data, 2010). Overall, however, the lower part of the Providence Mountains section is thicker, less dolomitic, more fossiliferous, and contains much less terrigenous sand than correlative rocks in the Ship Mountains, all consistent with a more northwesterly (offshore) paleogeographic position of the Providence Mountains. The dolomitic upper part of the Providence Mountains section is similar in thickness and lithology to member 5 of the Bird Spring Formation in the Ship Mountains, although the latter contains more terrigenous sand.

In the Blythe area, about $100 \mathrm{~km}$ southeast of the Ship Mountains, rocks interpreted as correlative with the Bird Spring Formation are assigned to the Supai Group (Miller, 1970; Varga, 1977; Hamilton, 1982; Stone and others, 1983; Brown, 1991). This unit, which is commonly about 200 to $400 \mathrm{~m}$ thick except where attenuated by extreme structural deformation, is composed primarily of thick-bedded calcareous sandstone and sandy limestone that have been metamorphosed to brown-weathering calc-silicate rocks in many areas. Relatively pure limestone or marble interbeds are present locally, but are subordinate to the associated sandy rocks. No fossils are known from the Supai Group of the Blythe area, but the lithology and stratigraphic relations of this unit support correlation with the Bird Spring Formation to the northwest (fig. 11). In particular, the brown-weathering sandy limestone, calcareous sandstone, and calc-silicate rocks of member 3 of the Bird Spring Formation in the Ship Mountains are very similar in lithology to much of the Supai Group in the Blythe area. This correlation provides lithostratigraphic evidence for interfingering of a sandy, southeasterly facies with a more calcareous, northwesterly facies of Pennsylvanian to lower Permian rocks.

About $250 \mathrm{~km}$ northeast of the Ship Mountains, approximately parallel to the regional trend of the late Paleozoic continental shelf, the Bird Spring Formation and equivalent units are widely exposed in southeastern Nevada and northwestern Arizona (fig. 1). In that region, the Callville Limestone and overlying Pakoon Limestone of the Virgin Mountains and Grand Wash Cliffs (McNair, 1951; Steed, 1980; McKee, 1982) form a sequence somewhat similar in lithology to (although thinner than) the Bird Spring Formation of the Ship Mountains. The lower part of this sequence (Callville Limestone) is primarily limestone and sandy limestone that can be correlated approximately with the lower part of the Ship Mountains section, whereas the overlying, dolomitic Pakoon Limestone can be correlated approximately with the upper part of the Ship Mountains section (fig. 11). Fusulinids (including Pseudoschwagerina) in the lower part of the Pakoon Limestone (McNair, 1951) probably correlate with the middle Wolfcampian fusulinid zone 3 of Stevens and Stone (2007) in southeastern California, providing a biostratigraphic link with member 4 of the Bird Spring Formation in the Ship Mountains. Pennsylvanian to lower Permian strata east of the Grand Wash Cliffs are more clastic than the Bird Spring Formation in the Ship Mountains (McKee, 1982), whereas coeval strata of the Bird Spring Formation to the west, as in the Arrow Canyon Range (fig. 1), are thicker, less dolomitic, and represent deeper water environments of deposition than coeval rocks of the Ship Mountains section (Cassity and Langenheim, 1966; Page, 1992, 1998).

The correlations discussed above support a Pennsylvanian to early Permian paleogeographic model in which an open-marine carbonate shelf (Bird Spring Shelf of Stevens and Stone, 2007) flanked a cratonal margin characterized by mixed carbonate and clastic sedimentation in very shallow water environments, with the clastic component increasing progressively eastward. Following Stevens and Stone (2007), we extend the transitional paleogeographic boundary between the shelf and the cratonal platform from a location between the Ship Mountains and the Blythe area in California northeastward to a location just east of the Grand Wash Cliffs in Arizona (fig. 12). This interpretation places the Ship Mountains and the Virgin Mountains areas at approximately analogous paleogeographic positions near the eastern margin of the Bird Spring Shelf.

Our tentative identification of the Lower Triassic Moenkopi Formation stratigraphically above the Bird Spring Formation in the Ship Mountains, if correct, indicates the absence of Permian units that overlie the Pakoon Limestone in the Virgin Mountains area and the Supai Group near Blythe (fig. 11). In the Mojave Desert, metamorphosed Permian strata interpreted to represent the Hermit Formation, Coconino Sandstone, Toroweap Formation, and Kaibab Formation are recognized as far northwest as the Kilbeck Hills, Old Woman Mountains, and Little Piute Mountains (fig. 1; Stone and others, 1983).

\section{Depositional History}

Deposition in carbonate-shelf settings like that represented by upper Paleozoic rocks in the Ship Mountains is controlled largely by water depth and distance from shore, which in turn are controlled by the interplay between eustatic sea level and the rate of subsidence of the shelf (Wilson, 1975). Here we summarize the depositional history of the Ship Mountains section and examine its possible relationship to changes in eustatic sea level and subsidence rates. In this discussion we refer to the late Paleozoic sea-level curves of Ross and Ross (1987) and Haq and Schutter (2008), which are broadly similar but differ in some important respects. Note that the trends in eustatic sea level discussed below are the broad, relatively long term, second-order trends depicted by the curves, not the third-order trends that 
PROVIDENCE MTS.

(Stevens and Stone, 2007)
SHIP MTS.

(This study)
BLYTHE AREA

(Stone and others, 1983)

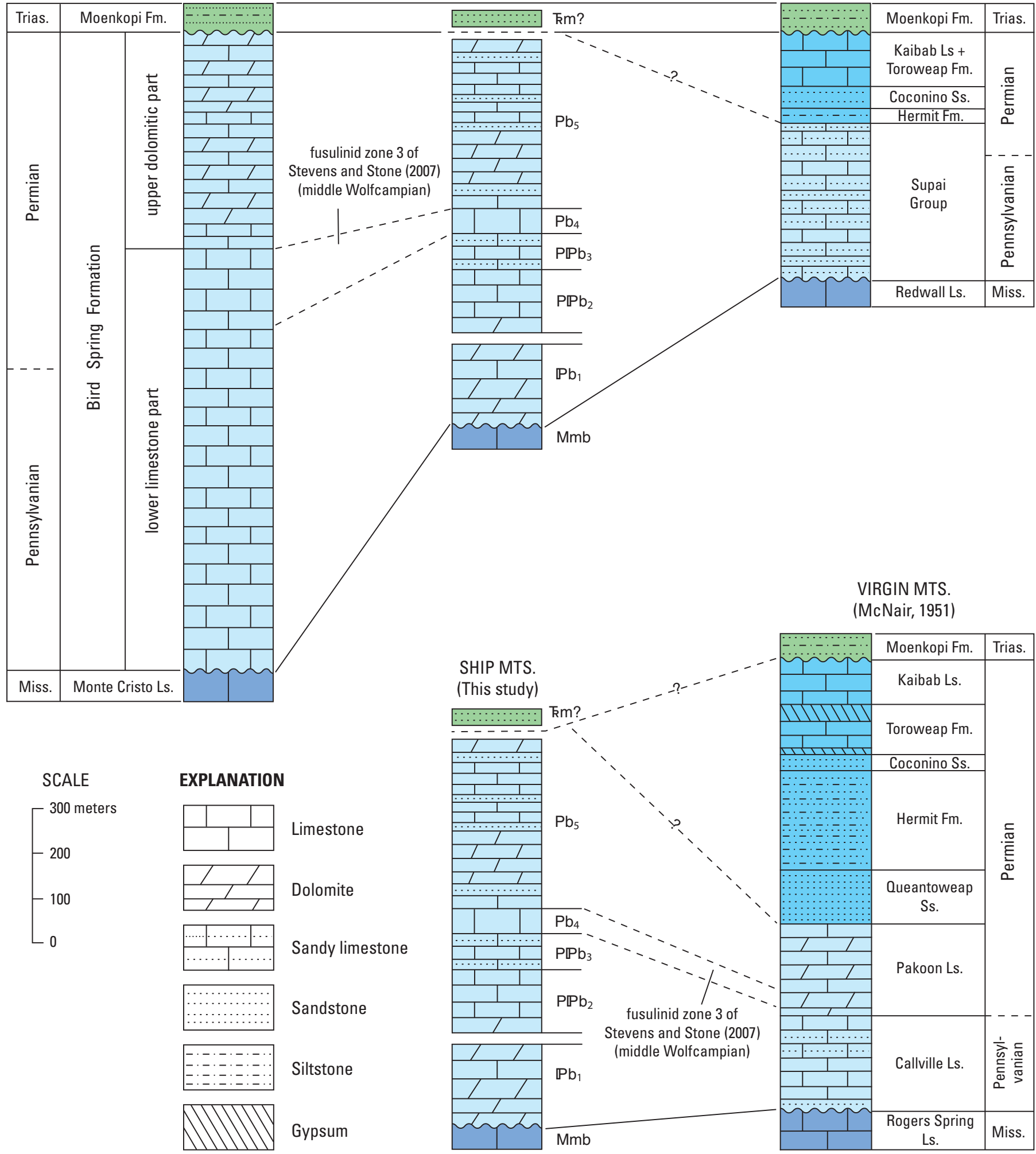

Figure 11. Simplified stratigraphic columns illustrating regional correlations between upper Paleozoic and Triassic(?) rocks in the Ship Mountains and coeval rocks in the Providence Mountains, the Blythe area, and the Virgin Mountains. See figure 1 for geographic locations of these areas and figure 4 for unit abbreviations and descriptions. 
reflect short term fluctuations of variable but often considerable magnitude.

The regionally extensive Mississippian carbonate shelf, represented in the Ship Mountains by the Bullion Member of the Monte Cristo Limestone, evolved during a period of generally high eustatic sea level (Ross and Ross, 1987; Haq and Schutter, 2008). The disconformable contact between the Bullion Member and the overlying Bird Spring Formation correlates with a major decline in eustatic sea level that exposed the shelf to subaerial exposure, erosion, and karstification during Late Mississippian time (Poole and Sandberg, 1977; Billingsley, 1999). This eustatic sea-level decline, whether sudden (Ross and Ross, 1987) or more gradual (Haq and Schutter, 2008), is generally interpreted to have resulted from the onset of southern-hemisphere (Gondwanan) glaciation (Bishop and others, 2009).

The Bird Spring Formation represents a renewal of carbonate-shelf sedimentation in the Early Pennsylvanian (Morrowan) following the Late Mississippian regression. Above the basal phosphatic limestone beds, the thick-bedded limestone and dolomite that compose most of the lower part (members 1 and 2) of the Bird Spring Formation in the Ship Mountains represent a shallow-water, carbonate-shelf environment. The general lithologic uniformity of this part of the Bird Spring Formation suggests relatively stable depositional conditions, although the change from predominantly dolomite and minor clastic rocks in member 1 and the lower part of member 2 to predominantly limestone in the upper part of member 2 probably reflects an increase in water depth through time. This change could have resulted from a general increase in eustatic sea level through the Pennsylvanian (Ross and Ross, 1987; Haq and Schutter, 2008) combined with more or less steady rates of subsidence and carbonate sedimentation on the shelf.

Member 3 of the Bird Spring Formation in the Ship Mountains marks an influx of terrigenous sand that put a temporary end to carbonate sedimentation on the shelf and represents a major change in depositional environment. The sandy beds of member 3 were presumably deposited in shallower water and closer to shore than the underlying limestone of member 2. A possible explanation for this change is provided by the sea-level curve of Ross and Ross (1987), which shows a sharp drop in eustatic sea level near the Pennsylvanian-Permian boundary, about the time member 3 might have been deposited. The curve of Haq and Schutter (2008) does not show a sudden drop in eustatic sea level at this time, but it does indicate a gradual decline through the earliest part of the Permian, which also could correlate with the deposition of member 3 . A decline in the rate of

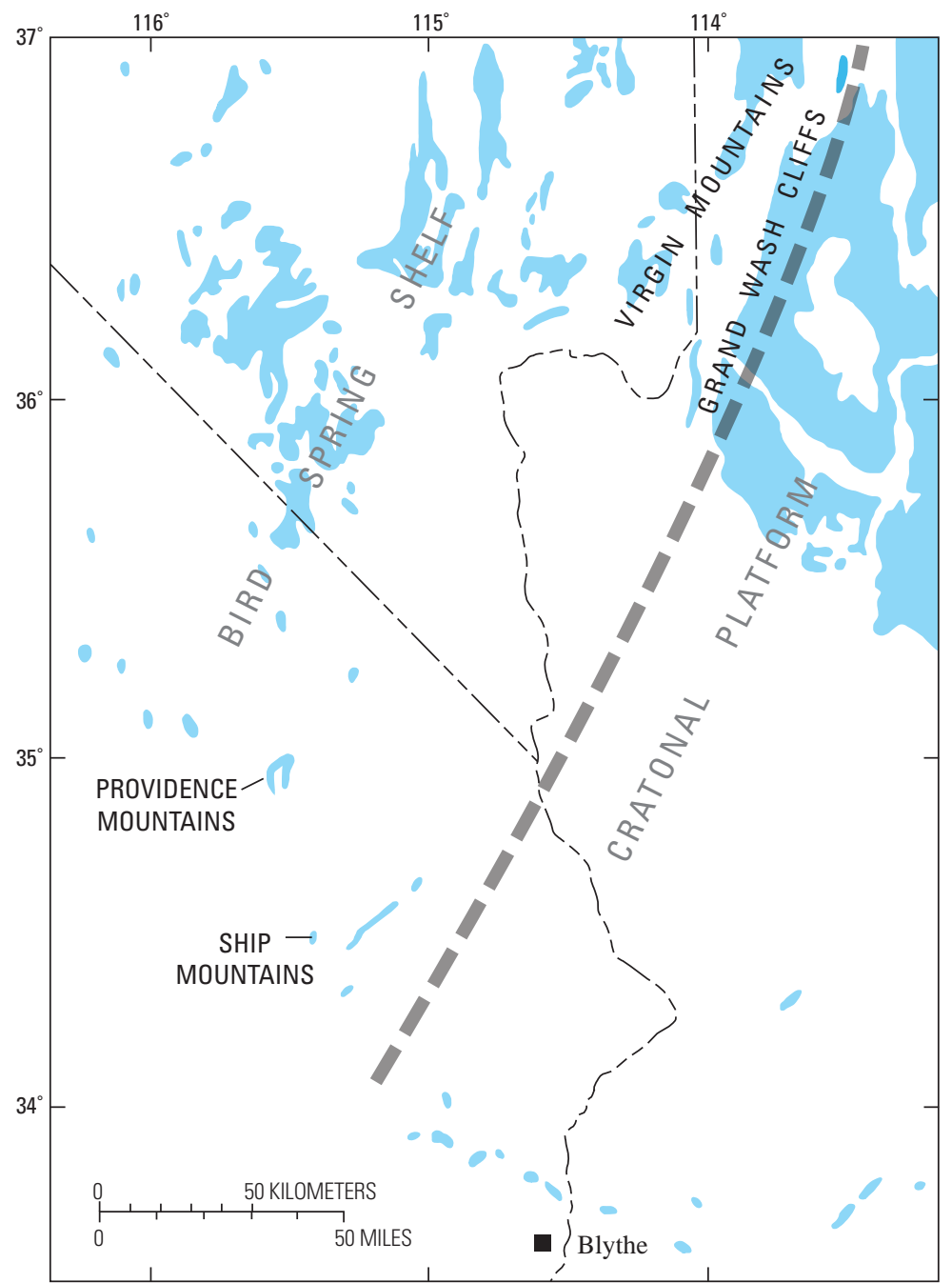

Figure 12. Upper Paleozoic outcrop map of southeastern California, southern Nevada, and northwestern Arizona (simplified from figure 1) showing interpreted paleogeographic boundary between the Pennsylvanian to early Permian Bird Spring Shelf and the coeval cratonal platform to the southeast. Outcrops of upper Paleozoic rocks (blue) are the same as those shown in figure 1.

subsidence or an increase in the availability of terrigenous sand, with or without a major decline in eustatic sea level, also could account for the deposition of member 3.

Above the sandy rocks of member 3 , the limestone beds of member 4 represent a change to open marine, shallow-water shelf conditions in which fusulinids and other marine organisms could thrive. We interpret this change to reflect a major marine transgression that both increased the water depth and prevented the influx of terrigenous sand onto this part of the shelf. A significant increase in eustatic sea level shown by Ross and Ross (1987) in the first half of the Early Permian (Wolfcampian to early Leonardian) provides a plausible explanation for this local change in depositional environment, although the curve of Haq and Schutter (2008) does not show a corresponding increase in sea level at this time. 
The change from the fossiliferous limestone of member 4 to the largely unfossiliferous limestone, dolomite, and sandstone of member 5 of the Bird Spring Formation represents another major change in depositional conditions. This change led to a very shallow water environment, largely inhospitable to marine organisms and marked by frequent incursions of terrigenous sand, which persisted through the deposition of member 5. Fusulinid biostratigraphy (this report) indicates that this shoaling event took place in the middle Wolfcampian, which the sea-level curves indicate was a time of either rising (Ross and Ross, 1987) or steady (Haq and Schutters, 2008) eustatic sea level. Thus, in this case, shoaling may have been caused not by a drop in eustatic sea level, but by depositional progradation of the carbonate shelf that in turn resulted from an increase in the rate of sedimentation relative to the rate of subsidence. However, a major drop in eustatic sea level did occur in late Permian time (Ross and Ross, 1987; Haq and Schutters, 2008), probably exposing rocks in the Ship Mountains area to subaerial erosion.

In summary, we interpret the late Paleozoic depositional history of the Ship Mountains to have been controlled by changes in eustatic sea level, subsidence rates, and sediment supply. Subsidence rates could have been influenced by late Paleozoic tectonism that was a major factor in controlling the depositional history of coeval rocks farther northwest in California, beyond the area of figure 1 (Stevens and Stone, 2007).

\section{Metamorphism}

Much of the sandy limestone and calcareous sandstone in the Bird Spring Formation and Moenkopi Formation(?) of the Ship Mountains has been partially to thoroughly metamorphosed to calc-silicate rock. A preliminary petrographic study reveals the following mineral assemblages: (1) quartz + tremolite; (2) calcite + diopside + quartz; (3) diopside + quartz + tremolite; (4) calcite + tremolite + quartz; and (5) calcite + tremolite + diopside + quartz. Plagioclase, scapolite, and chalcedony were also identified in some thin sections. The observed calcsilicate mineral assemblages, which formed by reactions between dolomite and quartz, have a broad range of stability under pressure-temperature conditions consistent with amphibolite-facies metamorphism. The dolomite required for these reactions probably formed largely or entirely by diagenetic replacement of calcium carbonate, the most common origin of dolomite in sedimentary rocks (Wilson, 1975).

One sample (SM-1), from a bed of metamorphosed limestone about $1 \mathrm{~m}$ thick near the base of member 2 of the Bird Spring Formation, is composed almost entirely of wollastonite. The presence of this bed suggests localized interaction with hot fluids rich in $\mathrm{H}_{2} \mathrm{O}$, which would enable the stabilization of wollastonite (Hoisch, 1987).

Further indication of the metamorphic grade is provided by the conodont alteration index (CAI) of samples S79SM-1 and -2 from member 1 of the Bird Spring Formation. The CAI of the conodonts in these samples is 6 , indicating a minimum host-rock temperature of at least $400^{\circ} \mathrm{C}$ (appendix 2).

\section{Summary}

Rocks assigned to to the Pennsylvanian and lower Permian Bird Spring Formation in the Ship Mountains consist of variably metamorphosed limestone, dolomite, and minor sandstone having an exposed stratigraphic thickness of about $900 \mathrm{~m}$. These rocks overlie massive limestone and marble assigned to the Mississippian Monte Cristo Limestone and are overlain by sandstone questionably assigned to the Triassic Moenkopi Formation. Fossils recovered from the Bird Spring Formation indicate an age of Early Pennsylvanian (Morrowan) to early Permian (Wolfcampian).

Strata of the Bird Spring Formation in the Ship Mountains were deposited in various shallow-water marine environments on the continental shelf of western North America. The Ship Mountains section lies between the thicker, less terrigenous, more seaward section of the Bird Spring Formation in the Providence Mountains, $55 \mathrm{~km}$ to the northwest, and the thinner, more terrigenous, more landward sections of the Supai Group near Blythe, $100 \mathrm{~km}$ to the southeast. The depositional history of the Bird Spring Formation reflects episodic fluctuations in eustatic sea level, subsidence rates, and terrigenous sediment supply. Tectonism along the continental margin to the northwest may have influenced subsidence rates.

Calc-silicate metamorphic mineral assemblages and conodont alteration index values indicate that the upper Paleozoic and Triassic(?) rocks in the Ship Mountains were subjected to amphibolite-facies metamorphism, presumably in conjunction with emplacement of the adjacent Late Jurassic granitoid pluton.

\section{References Cited}

Bentor, Y.K., 1980, Phosphorites-the unsolved problems, in Bentor, Y.K., ed., Marine phosphorites—geochemistry, occurrence, genesis: Society of Economic Paleontologists and Mineralogists Special Publication 29, p. 3-18. 
Billingsley, G.H., 1999, Erosional surfaces of the Surprise Canyon Formation, chap. D of Billingsley, G.H., and Beus, S.S., eds., Geology of the Surprise Canyon Formation of the Grand Canyon, Arizona: Flagstaff, Arizona, Museum of Northern Arizona Bulletin 61, p. 53-68.

Bishop, C.C., compiler, 1963, Geologic map of California, Needles sheet: California Division of Mines and Geology, scale 1:250,000.

Bishop, J.W., Montañez, I.P., Gulbranson, E.L., and Brenckle, P.L., 2009, The onset of mid-Carboniferous glacioeustasy—sedimentologic and diagenetic contraints, Arrow Canyon, Nevada: Palaeogeography, Palaeoclimatology, Palaeoecology, v. 276, p. 217-243.

Brown, H.J., 1991, Stratigraphy and paleogeographic setting of Paleozoic rocks in the San Bernardino Mountains, California, in Cooper, J.D., and Stevens, C.H., eds., Paleozoic paleogeography of the western United States-II: Society of Economic Paleontologists and Mineralogists, Pacific Section, Book 67, p. 193-207.

Carl, B.S., Miller, C.F., and Foster, D.A., 1991, Western Old Woman Mountains shear zone- evidence for late ductile extension in the Cordilleran orogenic belt: Geology, v. 19, p. 893-896.

Cassity, P.E., and Langenheim, R.L., Jr., 1966, Pennsylvanian and Permian fusulinids of the Bird Spring Group from Arrow Canyon, Clark County, Nevada: Journal of Paleontology, v. 40, no. 4, p. 931-968.

Collier, J.T., 1959, Geology and mineral resources of Township 5 North, Ranges 15 and 16 East, San Bernardino Base and Meridian, San Bernardino County, California: Southern Pacific Company, 22 p., scale 1:24,000.

Davydov, V., Wardlaw, B.R., and Gradstein, F.M., 2004, The Carboniferous Period, in Gradstein, F.M., Ogg, J.G., and Smith, A.G., eds., A geologic time scale 2004: Cambridge, UK, Cambridge University Press, p. 222-248.

Feray, D.E., Oetking, P., and Renfro, H.B., compilers, 1968, Geologic highway map of the Pacific Southwest Region (California and Nevada): American Association of Petroleum Geologists, United States Geological Highway Map Series, Map 3, scale approximately 1:1,900,800.

Foster, D.A., Miller, C.F., Harrison, T.M., and Hoisch, T.D., $1992,{ }^{40} \mathrm{Ar} /{ }^{39} \mathrm{Ar}$ thermochronology and thermobarometry of metamorphism, plutonism, and tectonic denudation in the Old Woman Mountains area, California: Geological Society of America Bulletin, v. 104, p. 176-191.
Gerber, M.E., Miller, C.F., and Wooden, J.L., 1995, Plutonism at the interior margin of the Jurassic magmatic arc, Mojave Desert, California, in Miller, D.M., and Busby, C., eds., Jurassic magmatism and tectonics of the North American Cordillera: Geological Society of America Special Paper 299, p. 351-373.

Hamilton, W., 1982, Structural evolution of the Big Maria Mountains, northeastern Riverside County, southeastern California, in Frost, E.G., and Martin, D.L., eds., MesozoicCenozoic tectonic evolution of the Colorado River region, California, Arizona, and Nevada: San Diego, Calif., Cordilleran Publishers, p. 1-28.

Haq, B.U., and Schutter, S.R., 2008, A chronology of Paleozoic sea-level changes: Science, v. 322, p. 64-68.

Hazzard, J.C., 1931, Paleozoic and associated rocks of the Marble and Ship Mountains, San Bernardino County, California: Berkeley, University of California, M.A. thesis, 98 p.

Hazzard, J.C., 1954, Rocks and structure of the northern Providence Mountains, San Bernardino County, California, chap. 4, no. 4 in Jahns, R.H., ed., Geology of southern California: San Francisco, California Division of Mines, Bulletin 170, p. 27-35.

Hoisch, T.D., 1987, Heat transport by fluids during Late Cretaceous regional metamorphism in the Big Maria Mountains, southeastern California: Geological Society of America Bulletin, v. 98, no. 5, p. 549-553.

Howard, K.A., 2002, Geologic map of the Sheep Hole Mountains 30' x 60' quadrangle, San Bernardino and Riverside Counties, California: U.S. Geological Survey Miscellaneous Field Studies MF-2344, scale 1:100,000.

Jennings, C.W., compiler, 1977, Geologic map of California: California Division of Mines and Geology, California Geologic Data Map Series, Map 2, scale 1:750,000.

Langenheim, R.L., Jr., and Larson, E.R. (co-chairmen, Eastern Nevada Geological Society Stratigraphic Committee), 1973, Correlation of Great Basin stratigraphic units: Nevada Bureau of Mines and Geology Bulletin 72, 36 p.

Law, B.E., 1969, Pennsylvanian-Permian conodont succession from the Bird Spring Formation, southeastern California: San Diego, Calif., San Diego State College, M.S. thesis, $84 \mathrm{p}$.

Longwell, C.R., Pampeyan, E.H., Bowyer, B., and Roberts, R.J., 1965, Geology and mineral deposits of Clark County, Nevada: Nevada Bureau of Mines and Geology Bulletin 62, $218 \mathrm{p}$. 
McKee, E.D., 1982, The Supai Group of Grand Canyon: U.S. Geological Survey Professional Paper 1173, 504 p.

McNair, A.H., 1951, Paleozoic stratigraphy of part of northwestern Arizona: American Association of Petroleum Geologists Bulletin, v. 35, p. 503-541.

Miller, C.F., Howard, K.A., and Hoisch, T.D., 1982, Mesozoic thrusting, metamorphism, and plutonism, Old Woman-Piute Range, southeastern California, in Frost, E.G., and Martin, D.L., eds., Mesozoic-Cenozoic tectonic evolution of the Colorado River region, California, Arizona, and Nevada: San Diego, Calif., Cordilleran Publishers, p. 561-581.

Miller, F.K., 1970, Geologic map of the Quartzsite quadrangle, Yuma County, Arizona: U.S. Geological Survey Geologic Quadrangle Map GQ-841, scale 1:62,500, 3 p.

Oetking, P., Feray, D.E., and Renfro, H.B., compilers, 1967, Geologic highway map of the Southern Rocky Mountain Region (Utah, Arizona, Colorado, and New Mexico): American Association of Petroleum Geologists, United States Geological Highway Map Series, Map 2, scale approximately 1:1,900,800.

Page, W.R., 1992, Preliminary geologic map of the Paleozoic rocks in the Arrow Canyon quadrangle, Clark County, Nevada: U.S. Geological Survey Open-File Report 92-681, scale $1: 24,000,14 \mathrm{p}$.

Page, W.R., 1998, Geologic map of the Arrow Canyon NW quadrangle, Clark County, Nevada: U.S. Geological Survey Geologic Quadrangle Map GQ-1776, scale 1:24,000.

Pettijohn, F.J., 1975, Sedimentary rocks (3d ed.): New York, Harper and Row, 628 p.

Poole, F.G., and Sandberg, C.A., 1977, Mississippian paleogeography and tectonics of the western United States, in Stewart, J.H., Stevens, C.H., and Fritsche, A.E., eds., Paleozoic paleogeography of the western United States, Pacific Coast Paleogeography Symposium 1: Society of Economic Paleontologists and Mineralogists, Pacific Section, Book 7, p. 67-85.

Rich, Mark, 1961, Stratigraphic section and fusulinids of the Bird Spring Formation near Lee Canyon, Clark County, Nevada: Journal of Paleontology, v. 35, p. 1159-1180.

Richard, S.M., Reynolds, S.J., Spencer, J.E., and Pearthree, P.A., compilers, 2000, Geologic map of Arizona: Arizona Geological Survey Map 35, scale 1:1,000,000.

Richards, B.C., Lane, H.R., and Brenckle, P.L., 2002, The IUGS mid-Carboniferous (Mississippian-Pennsylvanian) global boundary stratotype section and point at Arrow Canyon, Nevada, USA, in Hills, L.V., Henderson, C.M., and Bamber, E.W., eds., Carboniferous and Permian of the world: Canadian Society of Petroleum Geologists Memoir 19, p. 802-831.
Ross, C.A., and Ross, J.R., 1987, Late Paleozoic sea levels and depositional sequences: Cushman Foundation for Foraminiferal Research, Special Publication 24, p. 137149.

Steed, D.A., 1980, Geology of the Virgin River gorge, northwest Arizona: Brigham Young University Geology Studies, v. 27, part 3, p. 96-115.

Stevens, C.H., Klingman, D.S., Sandberg, C.A., Stone, P., Belasky, P., Poole, F.G., and Snow, J.K., 1996, Mississippian stratigraphic framework of east-central California and southern Nevada with revision of Upper Devonian and Mississippian stratigraphic units in Inyo County, California: U.S. Geological Survey Bulletin 1988J, p. J1-J39.

Stevens, C.H., and Stone, P., 2007, The PennsylvanianEarly Permian Bird Spring Carbonate Shelf, southeastern California—fusulinid biostratigraphy, paleogeographic evolution, and tectonic implications: Geological Society of America Special Paper 429, $82 \mathrm{p}$.

Stewart, J.H., and Carlson, J.E., 1977, Million-scale geologic map of Nevada: Nevada Bureau of Mines and Geology Map 57, scale 1:1,000,000.

Stewart, J.H., and Poole, F.G., 1975, Extension of the Cordilleran miogeosynclinal belt to the San Andreas Fault, southern California: Geological Society of America Bulletin, v. 86, no. 2, p. 205-212.

Stone, P., Howard, K.A., and Hamilton, W., 1983, Correlation of metamorphosed Paleozoic strata of the southeastern Mojave Desert region, California and Arizona: Geological Society of America Bulletin, v. 94, p. 1135-1147.

Thompson, M.L., and Hazzard, J.C., 1946, Permian fusulinids of southern California, part 3 of Thompson, M.L., Wheeler, H.E., and Hazzard, J.C., 1946, Permian fusulinids of California: Geological Society of America Memoir 17, p. 37-71.

U.S. Geological Survey Geologic Names Committee, 2010, Divisions of geologic time-major chronostratigraphic and geochronologic units: U.S. Geological Survey Fact Sheet 2010-3059, 2 p.

Varga, R.J., 1977, Geology of the Socorro Peak area, western Harquahala Mountains: Arizona Bureau of Geology and Mineral Technology, Circular 20, 20 p.

Wardlaw, B.R., Davydov, V., , and Gradstein, F.M., 2004, The Permian Period, in Gradstein, F.M., Ogg, J.G., and Smith, A.G., eds., A geologic time scale 2004: Cambridge, UK, Cambridge University Press, p. 249-270.

Wilson, J.L., 1975, Carbonate facies in geologic history: New York, Springer-Verlag, $471 \mathrm{p}$. 


\section{Appendix 1. Measured Sections}

[The following information applies to appendixes 1,2 , and $\underline{3}$. Map locality numbers refer to figure 4 and table 1 . Latitude (north) and longitude (west) values of selected localities are given in degrees, minutes, and seconds, with latitude followed by longitude; for example, $34^{\circ} 30^{\prime} 12^{\prime \prime}$, $115^{\circ} 24^{\prime} 5^{\prime \prime}$. GPS latitude and longitude coordinates (labeled "GPS location") were determined in the field with a Garmin eTrex 12-channel GPS unit; other latitude and longitude coordinates (labeled "Mapped location”) were measured from locations plotted on topographic maps. Latitudes and longitudes are referenced to the 1927 North American Datum (NAD27). See plate 1 for detailed graphic columns]

\section{Section SM}

Section SM, measured by Paul Stone in October 1978, includes members 2-5 of the Bird Spring Formation on hills 1 and 2 (see fig. 4 for location).

\begin{tabular}{|c|c|c|}
\hline & $\begin{array}{l}\text { Thickness, } \\
\text { in meters }\end{array}$ & $\begin{array}{l}\text { Cumulative } \\
\text { thickness, } \\
\text { in meters }\end{array}$ \\
\hline \multicolumn{3}{|l|}{ Top of section covered with granitoid boulders. Mapped location: $34^{\circ} 30^{\prime} 12^{\prime \prime}, 115^{\circ} 24^{\prime} 57^{\prime \prime}$} \\
\hline \multicolumn{3}{|l|}{ Bird Spring Formation (Pennsylvanian and Permian) (incomplete): } \\
\hline \multicolumn{3}{|l|}{ Member 5 (Permian) (incomplete): } \\
\hline 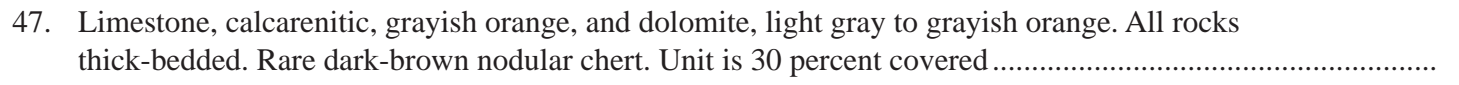 & 14.3 & 663.5 \\
\hline $\begin{array}{l}\text { 46. Dolomite, very fine grained, grayish orange. Bedding indistinct. Sample SM-57, } 3 \mathrm{~m} \\
\text { above base of unit }\end{array}$ & 5.2 & 649.2 \\
\hline \multicolumn{3}{|l|}{ 45e. Limestone, calcarenitic, grayish orange, grading up into dolomite, very fine grained, grayish orange. } \\
\hline Forms ledge & 0.9 & 644.0 \\
\hline 45d. Dolomite, very fine grained, grayish orange, poorly bedded... & 5.1 & 643.1 \\
\hline 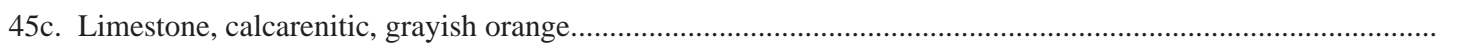 & 2.1 & 638.0 \\
\hline \multicolumn{3}{|l|}{ 45b. Limestone, fine grained, grayish orange to medium gray. Sample SM-56, grayish-orange limestone } \\
\hline \multicolumn{3}{|l|}{$\begin{array}{l}\text { 45a. Sandstone and quartzite, calcareous, very light gray, plane laminated; mostly weathers } \\
\text { rusty brown. Poorly exposed, forming low, hummocky outcrops. Sample SM-54, } 4.6 \mathrm{~m} \\
\text { above base of unit }\end{array}$} \\
\hline 44e. Limestone, fine grained, light gray to grayish orange & 0.8 & 621.9 \\
\hline 44d. Limestone, fine grained, light gray to grayish orange, poorly exposed & 3.7 & 621.1 \\
\hline \multicolumn{3}{|l|}{ 44c. Sandstone, calcareous, light gray to grayish orange, plane laminated; weathers rusty brown. } \\
\hline 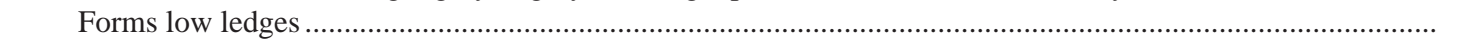 & 3.7 & 617.4 \\
\hline 44b. Limestone, fine grained, light gray to grayish orange, and dolomite, fine grained, grayish orange.................... & 4.3 & 613.7 \\
\hline \multirow{2}{*}{\multicolumn{3}{|c|}{$\begin{array}{l}\text { 44a. Dolomite and limestone, fine grained, light gray to grayish orange, medium bedded, in part sandy; and } \\
\text { limestone, fine grained, medium gray, medium to thick bedded, ledge forming. Two thin beds of very fine } \\
\text { grained calcareous quartzite are present } 8.2 \text { and } 9.4 \mathrm{~m} \text { above base of unit. Sample SM-53, grayish-orange } \\
\text { limestone, } 11.2 \mathrm{~m} \text { above base of unit; sample SM-52, calcareous quartzite, } 8.2 \mathrm{~m} \text { above base of unit; sample } \\
\text { SM-51, medium-gray limestone, } 6 \mathrm{~m} \text { above base of unit; sample SM-50, dolomite, } 2 \mathrm{~m} \text { above base of unit.... }\end{array}$}} \\
\hline & & \\
\hline 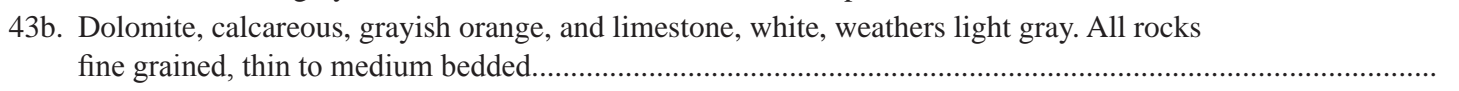 & 5.2 & 593.7 \\
\hline $\begin{array}{l}\text { 43a. Limestone, silty, medium gray, weathers light gray, medium bedded; has faint plane lamination ..................... } \\
\text { [Note: Minor structural complications associated with a fine-grained diorite dike (unit Jfd, fig. } 4 \text { ) that crosses } \\
\text { section, resulting in duplication of units 42a-d.] }\end{array}$ & 1.5 & 588.5 \\
\hline 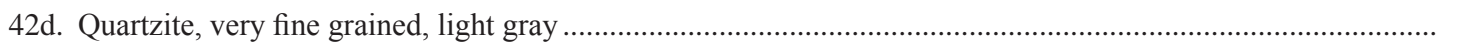 & 0.2 & 587.0 \\
\hline 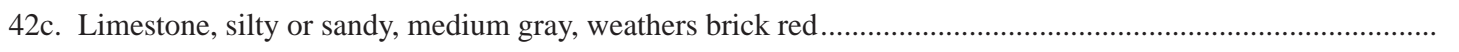 & 0.5 & 586.8 \\
\hline $\begin{array}{l}\text { 42b. Limestone, silty, medium gray; contains abundant fossil debris, mostly echinoid spines } \\
\text { and echinodermal debris }\end{array}$ & 0.5 & 586.3 \\
\hline 42a. Limestone, silty or sandy, medium gray, v & 0.6 & 585.8 \\
\hline
\end{tabular}


41f. Limestone, dolomitic(?), grayish orange, and limestone, medium gray. Uppermost $0.3 \mathrm{~m}$ is a medium-dark-gray, highly fossiliferous marker bed that contains large articulated brachiopods and echinodermal debris....

41e. Covered interval.

41d. Limestone, dolomitic(?), grayish orange, and limestone, medium gray. Upper bedding surface of unit is strewn with fossil debris including echinoid spines and other echinodermal debris

41c. Limestone, dolomitic(?), grayish orange, and limestone, medium gray, medium to thick bedded. Chert nodules common

41b. Dolomite, thick-bedded, as in 41a. Includes one thin bed of fossiliferous silty limestone $2 \mathrm{~m}$ above base of unit

41a. Dolomite, slightly calcareous, fine grained, grayish orange, thick bedded to massive, very resistant. Chert nodules common

40f. Limestone, fine grained, in part silty or sandy, possibly in part dolomitic; medium gray to grayish orange, medium bedded. Sample SM-44, $1 \mathrm{~m}$ above base of unit

40e. Limestone, very fine grained, grayish orange to medium gray, forms low ledges. Some nodular chert present.

40c. Quartzite, very fine grained, light gray, weathers rusty brown, plane laminated, highly fractured...

40b. Limestone, sandy, calcarenitic, as in 40a but weathers light gray

40a. Limestone, sandy, calcarenitic, grayish orange, weathers rusty brown; plane laminated.

[Note: Units 39c-i combine to form a conspicuous ledge $4.5 \mathrm{~m}$ thick.]

39i. Limestone, aphanitic, medium gray to grayish orange; chert nodules at top

39h. Limestone, aphanitic, grayish orange

39g. Limestone, fine grained, gray, medium-bedded; mostly covered .

39f. Limestone, very fine grained, medium gray; abundant fossil debris at top ...

39e. Limestone, aphanitic, grayish orange to medium gray; chert nodules at top. Unit contains small articulated brachiopods

39d. Limestone, very fine grained, grayish orange, massive; contains irregular brown chert nodules .....

39c. Limestone, very fine grained, medium gray, massive; weathers grayish orange in spots. Contains scattered fossil (mainly echinodermal) debris.

39b. Siltstone, calcareous

39a. Limestone, fine grained, light to medium gray; weathers light brown. Middle part contains a 1-cm-thick brown sandy layer.

38h. Limestone, fine to medium grained, grayish orange to medium gray, medium bedded

38g. Quartzite, very fine grained, finely laminated, highly fractured. Weathered surface is banded brown and white on a millimeter scale

38f. Limestone, calcarenitic, probably with quartz sand......

38e. Covered interval.

38d. Quartzite, calcareous, weathers rusty brown, as in 38a.

38c. Limestone, fine to medium grained, grayish orange, medium bedded. Rock is very soft, weathers to a recessive slope

38b. Covered interval.

38a. Quartzite, calcareous, very fine grained, light gray, weathers rusty brown, plane laminated. Sample SM-41, $0.3 \mathrm{~m}$ above base of unit.

37. Limestone, medium to coarse grained, grayish orange, weathers light gray, medium bedded, as in 36a-b ........

36b. Limestone, medium to coarse grained, as in 36a

36a. Limestone, medium to coarse grained, grayish orange, medium bedded..

35e. Limestone, fine to medium grained, grayish orange, thin to medium bedded. Unit is about 50 percent covered. Sample SM-40, 2 m above base of unit

35c. Interval mostly covered; some outcrops of limestone and dolomite as in 35a-b.

35b. Limestone, medium to coarse grained, probably sandy, grayish orange, weathers light gray. Forms ledge ....... 
35a. Dolomite, very fine grained, light to medium gray.

34c. Limestone, sandy, light gray, medium to thick bedded.

34b. Sandstone, calcareous, light gray, weathers dark brown

34a. Dolomite, very fine grained, light gray, medium bedded (beds generally 15 to $30 \mathrm{~cm}$ thick). Brown nodular to lenticular chert common. Unit becomes more calcareous and coarser grained upward. Sample SM-39, $30 \mathrm{~m}$ above base; sample SM-38, $14 \mathrm{~m}$ above base.

33b. Interval covered by Tertiary volcanic rocks and rubble (Peach Spring Tuff, unit Tps, fig. 4).....

33a. Interval is 75 percent covered. Scattered outcrops of light-gray dolomite

32b. Dolomite, very fine grained; grades upward from medium to light gray. Contains large brown chert nodules

32a. Dolomite, fine grained, light gray, weathers light brown. Lower part of unit contains white to light-gray limestone. Medium to thick bedded; beds are somewhat nodular. Unit is 20 percent covered......

31. Covered interval in wash

[GPS location of base of unit 31 is 34³0'26.9", 115²4'59.8", as determined in March 2010.]

30b. Dolomite, fine grained, light gray, massive, resistant; forms ledge. Chert nodules on upper bedding surface

30a. Limestone, white, nonresistant, thin to medium bedded. Chert nodules and quartz geodes common on bedding planes

29f. Limestone, white, nonresistant, thick bedded to massive; commonly weathers to a nodular appearance.

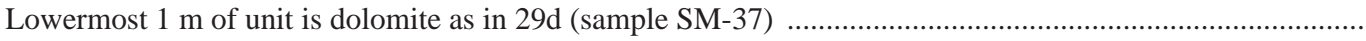

29e. Covered interval

29d. Dolomite, fine grained, reddish gray, weathers light gray, massive. Sample SM-36, 4.7 m above base of unit

29c. Covered interval....

29b. Quartzite, very fine grained, light gray, weathers dark brown

29a. Covered interval.

28e. Limestone, medium gray, weathers light gray; contains abundant fossil debris including rare fusulinids .........

28d. Quartzite, calcareous, fine grained, grayish orange; grades up from underlying limestone. Contains abundant echinodermal debris

28c. Limestone, aphanitic, containing locally abundant fusulinids and other fossil debris. Sample SM-35, from basal part of unit.

28b. Limestone, with quartz sand, medium gray, weathers grayish orange, massive

28a. Covered interval

27h. Quartzite, calcareous, fine grained, light gray to grayish orange, thick bedded, with local plane and cross lamination

27g. Quartzite, fine grained, light gray, weathers dark brown, massive. Sample SM-34, 3 m above base of unit

27f. Quartzite, calcareous, and limestone, with quartz sand, fine grained, light gray, weathers light gray to grayish orange, plane laminated

27e. Covered interval

27d. Quartzite and sandstone, calcareous

27c. Quartzite, fine grained, light greenish gray, weathers brown, massive.

27b. Covered interval

27a. Limestone, aphanitic, medium gray, weathers light brown to grayish orange, massive.

26j. Limestone, very fine grained, medium gray, massive, forms ledge. Bioclastic debris, including

fusulinids, locally abundant. Sample SM-33, from basal part of unit

26i. Calc-silicate rock, fine grained, light gray, with blocky fracture. Sample SM-32.

26h. Covered interval

26g. Limestone, sandy, fine grained, light gray, plane laminated. Sample SM-31

26f. Interval is mostly covered. Some outcrops of nonresistant limestone......

26e. Limestone, fine grained, pinkish gray, weathers light gray

26d. Covered interval
Thickness,
in meters

5.5

1.4

0.3

33.2

27.6

12.7

0.9
Cumulative thickness,

in meters

482.0

476.5

475.1

474.8

441.6

414.0

401.3

400.4

392.8

367.9

366.4

359.5

353.5

350.8

343.1

336.6

334.5

333.4

332.6

331.4

330.2

329.4

328.0

324.3

317.3

315.8

315.0

314.2

313.7

313.1

312.5

311.4

310.6

309.2

308.3

306.5

306.2 


\begin{tabular}{|c|c|c|}
\hline & $\begin{array}{l}\text { Thickness, } \\
\text { in meters }\end{array}$ & $\begin{array}{l}\text { Cumulative } \\
\text { thickness, } \\
\text { in meters }\end{array}$ \\
\hline 26c. Limestone, white, weathers grayish orange & 1.2 & 305.3 \\
\hline 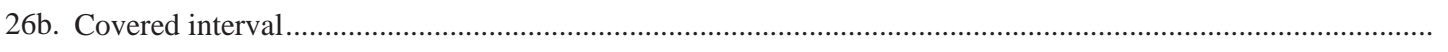 & 0.6 & 304.1 \\
\hline 26a. Limestone, light gray to grayish orange, mottled; possibly in part dolomitic. Sample SM-30 ........................... & 0.3 & 303.5 \\
\hline 25e. Limestone, fine grained, nonresistant, as in $25 \mathrm{~d}$. Forms recessive slope. Unit is about 25 percent & 13.3 & 303.2 \\
\hline $\begin{array}{l}\text { 25d. Limestone, fine grained, nearly white, weathers light gray to grayish orange, nonresistant. } \\
\text { Sample SM-29 }\end{array}$ & 0.6 & 289.9 \\
\hline 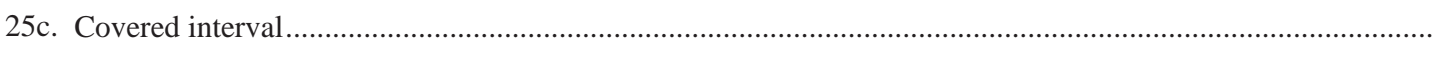 & 1.3 & 289.3 \\
\hline 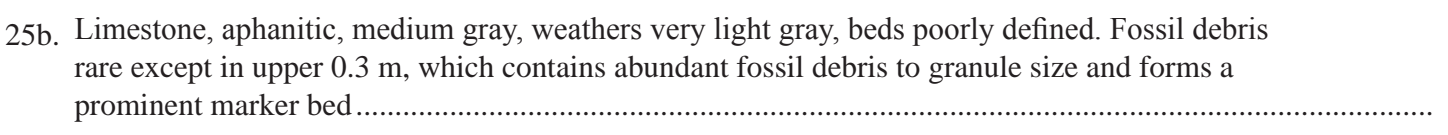 & 2.4 & 288.0 \\
\hline 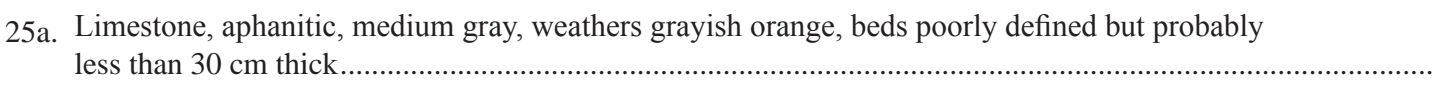 & 2.1 & 285.6 \\
\hline $\begin{array}{l}\text { 24b. Limestone, aphanitic, medium to medium dark gray, weathers grayish orange; forms ledge. } \\
\text { Beds poorly defined, probably } 30 \text { to } 60 \mathrm{~cm} \text { thick }\end{array}$ & 2.1 & 283.5 \\
\hline $\begin{array}{l}\text { 24a. Interval mostly covered. Few outcrops of medium-gray aphanitic limestone, weathers grayish } \\
\text { orange, recessive }\end{array}$ & $\underline{2.0}$ & 281.4 \\
\hline Incomplete thickness of member 5 & $\underline{\underline{384.1}}$ & \\
\hline \multicolumn{3}{|l|}{ Member 4 (Permian): } \\
\hline 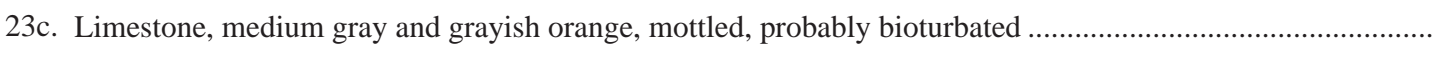 & 0.3 & 279.4 \\
\hline $\begin{array}{l}\text { 23b. Limestone, aphanitic, dark gray. Contains rare fossil debris. Upper surface of unit has very } \\
\text { large brown chert nodules }\end{array}$ & 0.3 & 279.1 \\
\hline 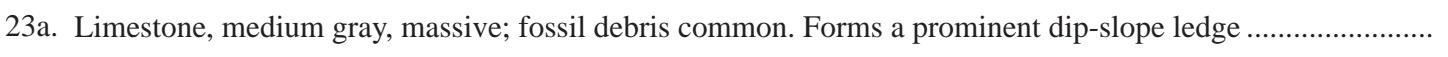 & 1.8 & 278.8 \\
\hline 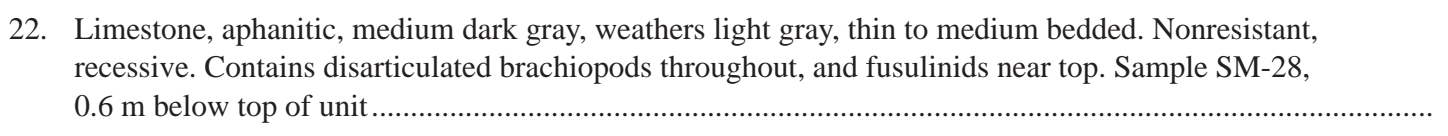 & 4.2 & 277.0 \\
\hline 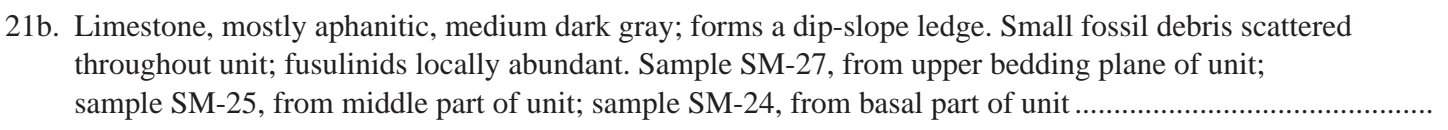 & 1.8 & 272.8 \\
\hline 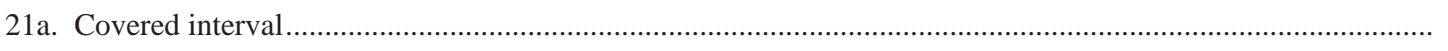 & 1.2 & 271.0 \\
\hline $\begin{array}{l}\text { 20. Limestone, aphanitic to bioclastic, light to medium gray, thick bedded to massive. Fossil debris } \\
\text { common, but fusulinids rare. Unit forms crest of ridge. Sample SM-23, } 3.4 \text { m above base of unit .................... }\end{array}$ & 9.1 & 269.8 \\
\hline $\begin{array}{l}\text { 19c. Limestone, light to medium gray, mottled, thick bedded to massive; chert nodules common, } \\
\text { especially in lower } 2 \mathrm{~m} \text {. Fusulinids and other fossil debris common, especially in light gray rocks................... }\end{array}$ & 3.7 & 260.7 \\
\hline 19b. Limestone, micritic in lower part to bioclastic in upper part, medium gray, massive; forms a & 1.4 & 257.0 \\
\hline 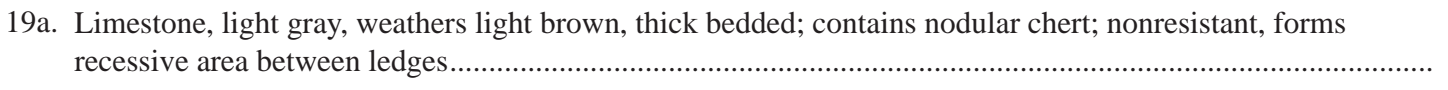 & 3.8 & 255.6 \\
\hline 18g. Limestone, possibly dolomitic, light brown, contains abundant brown chert nodules...................................... & 0.9 & 251.8 \\
\hline 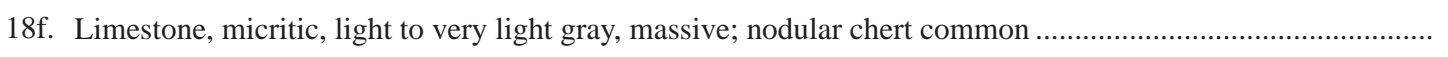 & 1.2 & 250.9 \\
\hline 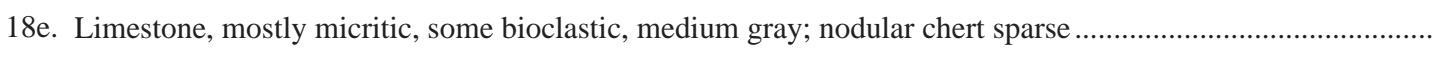 & 1.8 & 249.7 \\
\hline 18d. Limestone, micritic, light to very light gray, massive; nodular chert common in upper 0.5 m ........................... & 3.4 & 247.9 \\
\hline 18c. Limestone, micritic, light gray, finely laminated & 1.5 & 244.5 \\
\hline 18b. Limestone, micritic, light to medium gray, massive; forms ledge. Fusulinids locally abundant......................... & 3.0 & 243.0 \\
\hline 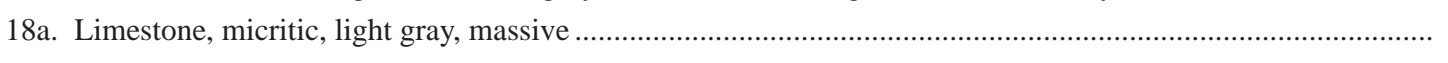 & 0.8 & 240.0 \\
\hline 17e. Limestone, micritic, light gray & 0.6 & 239.2 \\
\hline $\begin{array}{l}\text { 17d. Limestone, micritic, medium gray, with some grayish orange silty lenses. Mottled, with some } \\
\text { nodular chert. Echinoderm debris locally abundant }\end{array}$ & 4.0 & 238.6 \\
\hline 17c. Limestone, micritic, in part silty, massive. Fusulinids abundant in upper 0.3 m (sample SM-18)...................... & 1.2 & 234.6 \\
\hline 17b. Limestone, micritic, possibly silty, light gray, weathers grayish orange . & 0.5 & 233.4 \\
\hline
\end{tabular}




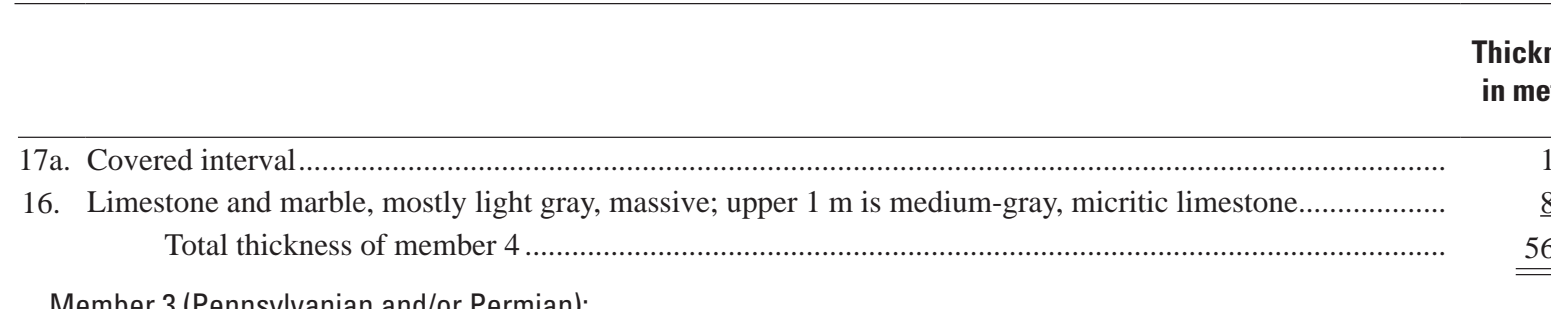

Member 3 (Pennsylvanian and/or Permian):

15c. Sandstone, calcareous, light gray, weathers reddish brown. Sample SM-16, from middle of unit ..........................

15b. Limestone, calcarenitic, sandy.....

15a. Sandstone, calcareous, light gray, weathers reddish brown, thick bedded. Minor calc-silicate metamorphism. Gradational from $14 \mathrm{~b}$

14b. Calc-silicate rock, light gray, thick bedded to massive, highly resistant. Sample SM-15, from basal part of unit.

14a. Quartzite and calc-silicate rock, weathers dark brown, massive, as in 13b. Plane lamination locally present in quartzite..

13b. Calc-silicate rock, white, weathers dark brown, massive; minor quartzite. Less metamorphosed parts of unit are light-gray sandy limestone. Sample SM-14, 4 m above base of unit

13a. Quartzite and calc-silicate rock, very fine grained, light gray, weathers dark brown, massive. Sample SM-13, $3 \mathrm{~m}$ above base of unit

12d. Limestone, aphanitic, medium gray; partly metamorphosed to massive, white marble.

12c. Calc-silicate rock and quartzite, weathers dark brown. Sample SM-12, $2.5 \mathrm{~m}$ above base of unit...

12b. Limestone, aphanitic, medium gray.....

12a. Quartzite, calcareous, fine grained, light gray, weathers dark brown, massive; partly metamorphosed to calc-silicate rock

11f. Marble, white, massive; forms ledge. Rare dark siliceous bands and nodules

11e. Marble, white, containing abundant brown siliceous laminae. Forms a persistent dark brown marker bed. Sample SM-11.

11d. Marble, white, forms a massive ledge. Contains wavy, light brown, siliceous stringers that produce a nodular appearance...

11c. Marble as in 11a, mostly covered .

11b. Limestone, sandy, weathers dark brown...

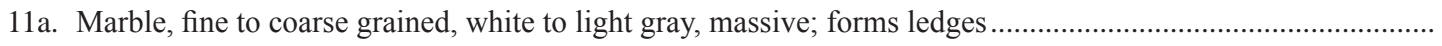

10d. Limestone, sandy, or sandstone, calcareous, as in $10 \mathrm{~b} . .$.

10c. Quartzite, calcareous, light gray, weathers dark brown ......

10b. Sandstone, calcareous, and limestone, calcarenitic, sandy, light gray, weathers dark brown,

massive; plane and cross lamination present locally. Metamorphosed to white calc-silicate rock in places. Sample SM-10, from basal part of unit..

10a. Marble, white

9h. Quartzite and calc-silicate rock, weathers brown, massive. Sample SM-9, $1.8 \mathrm{~m}$ above base of unit.

9g. Marble, white to light gray.....

9f. Calc-silicate rock, white, weathers brown; some white marble interbedded with brown siliceous

9e. Quartzite and calc-silicate rock, fine grained, light gray, weathers dark brown, massive. Sample

9d. Limestone, calcarenitic, fine grained, light gray, weathers dark brown, plane to cross laminated. Parts of unit metamorphosed to calc-silicate rock.....

9c. Limestone, aphanitic, medium gray, massive; partly metamorphosed to white marble

9b. Covered interval.

9a. Limestone, sandy, fine grained, light gray, weathers dark brown. Sample SM-7.

\section{Member 2 (Pennsylvanian and/or Permian) (incomplete):}

8d. Marble, white to light gray, massive.

8c. Calc-silicate rock, white, laminated; forms ledge.

8b. Marble, white to light gray, massive; faint plane lamination present in many places. Minor 


\begin{tabular}{|c|c|c|}
\hline & $\begin{array}{l}\text { Thickness, } \\
\text { in meters }\end{array}$ & $\begin{array}{c}\text { Cumulative } \\
\text { thickness, } \\
\text { in meters }\end{array}$ \\
\hline $\begin{array}{l}\text { 8a. Marble, light gray; limestone, medium gray; and bands of light-brown-weathering calc-silicate } \\
\text { rock and/or chert } 1 \text { to } 5 \mathrm{~cm} \text { thick }\end{array}$ & 4.5 & 122.1 \\
\hline 7c. Marble, white to light gray, massive. Sample SM-6, $5 \mathrm{~m}$ above base of unit & 17.7 & 117.6 \\
\hline $\begin{array}{l}\text { 7b. Marble, light gray, containing bands of calc-silicate rock to } 2 \mathrm{~cm} \text { thick. Sample SM-5, } 0.3 \mathrm{~m} \\
\text { below top of unit }\end{array}$ & 6.0 & 99.9 \\
\hline 7a. Marble, light gray. & 1.4 & 93.9 \\
\hline 6d. Marble, chert-banded ................................. & 0.9 & 92.5 \\
\hline 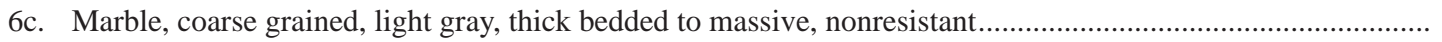 & 18.8 & 91.6 \\
\hline 6b. Marble, chert-banded & 0.8 & 72.8 \\
\hline 6а. Marble, in part dolomitic, coarse grained, white, weathers light brown, massive; forms slope.............................. & 4.7 & 72.0 \\
\hline 5c. Marble, white, with some patches of medium-gray aphanitic limestone (probably the original rock type) ........ & 5.2 & 67.3 \\
\hline 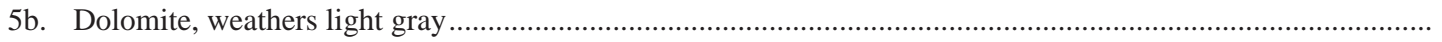 & 0.3 & 62.1 \\
\hline 5a. Marble, white, weathers light gray, massive; forms cliff. & 6.1 & 61.8 \\
\hline 4f. Marble, coarse grained, white; partly altered to light-brown-weathering dolomite ……................................... & 10.5 & 55.7 \\
\hline 4e. Limestone, aphanitic, medium gray. Sample SM-4.. & 1.3 & 45.2 \\
\hline 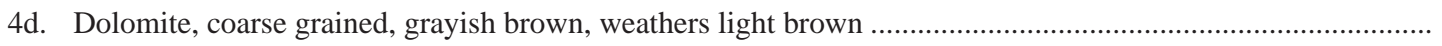 & 2.6 & 43.9 \\
\hline 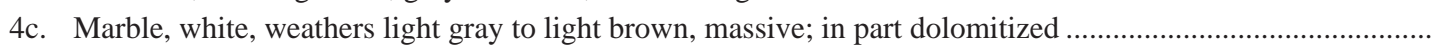 & 3.4 & 41.3 \\
\hline 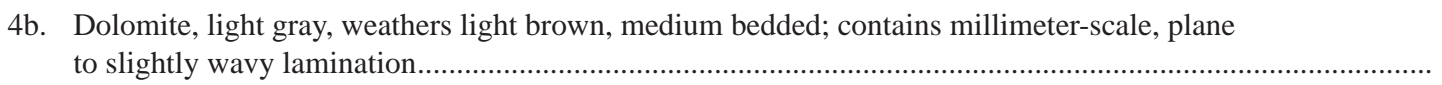 & 1.8 & 37.9 \\
\hline 4a. $\quad$ Dolomite, massive, as in $3 f$ & 1.3 & 36.1 \\
\hline 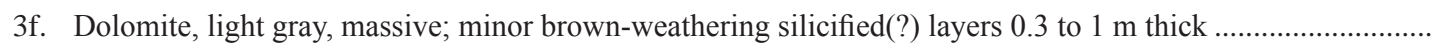 & 9.3 & 34.8 \\
\hline 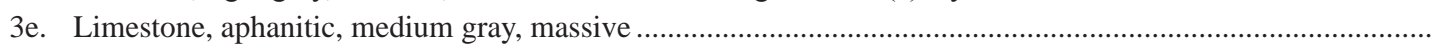 & 0.3 & 25.5 \\
\hline 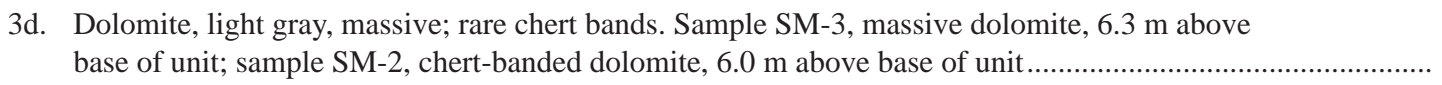 & 8.0 & 25.2 \\
\hline 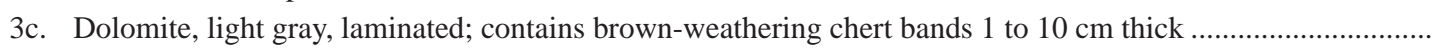 & 1.6 & 17.2 \\
\hline 3b. Limestone, aphanitic, medium gray, massive & 1.4 & 15.6 \\
\hline 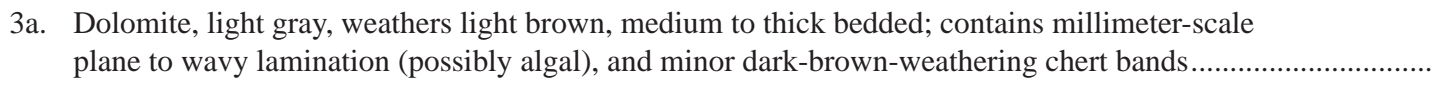 & 3.0 & 14.2 \\
\hline 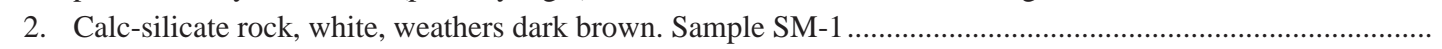 & 0.9 & 11.2 \\
\hline 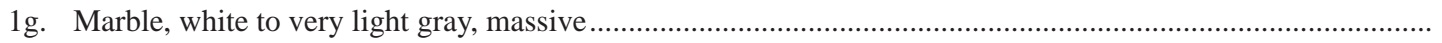 & 0.6 & 10.3 \\
\hline 1f. Marble, light gray, massive & 0.4 & 9.7 \\
\hline 1e. Dolomite, light gray, as in 1a & 2.2 & 9.3 \\
\hline 1d. Marble, white, massive & 1.2 & 7.1 \\
\hline 1c. Dolomite, light gray, as in 1a & 1.6 & 5.9 \\
\hline 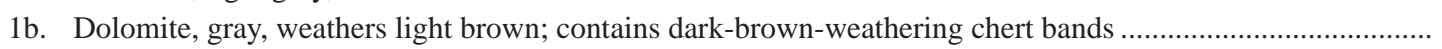 & 0.4 & 4.3 \\
\hline 1a. Dolomite, medium grained, light gray, massive & $\underline{3.9}$ & 3.9 \\
\hline Incomplete thickness of member 2 & $\underline{141.6}$ & \\
\hline 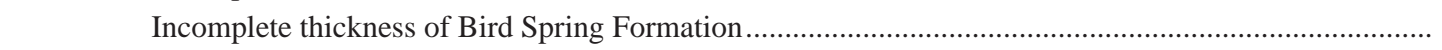 & 663.5 & \\
\hline section covered by alluvium at foot of slope. Mapped location: $34^{\circ} 30^{\prime} 27.5^{\prime \prime}, 115^{\circ} 25^{\prime} 51.5^{\prime \prime}$. & & \\
\hline
\end{tabular}




\section{Section SM2}

Section SM2, measured by Paul Stone and C.H. Stevens in March 2010, includes the Bullion Member of the Monte Cristo Limestone and member 1 of the Bird Spring Formation on hill 1 (see fig. 4 for location). Cumulative thicknesses are from base of the Bird Spring Formation.

\begin{tabular}{|c|c|c|}
\hline & $\begin{array}{l}\text { Thickness, } \\
\text { in meters }\end{array}$ & $\begin{array}{l}\text { Cumulative } \\
\text { thickness, } \\
\text { in meters }\end{array}$ \\
\hline \multicolumn{3}{|l|}{$\begin{array}{l}\text { Top of section at or near fault contact with upper part of Bird Spring Fol } \\
\text { Bird Spring Formation (Pennsylvanian and Permian) (incomplete): } \\
\text { Member } 1 \text { (Pennsylvanian) (incomplete): }\end{array}$} \\
\hline 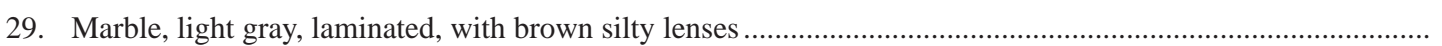 & 5.0 & 183.0 \\
\hline 27. Dolomite, buff................ & 5.0 & 176.5 \\
\hline 26. Marble, light gray...... & 9.0 & 171.5 \\
\hline 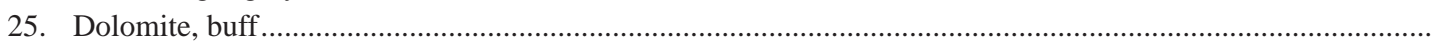 & 3.0 & 162.5 \\
\hline 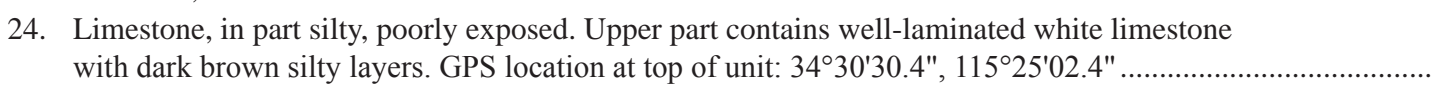 & 11.0 & 159.5 \\
\hline \multicolumn{3}{|l|}{ 20. Limestone, light gray, weathers ochre. Top of unit is faulted against upper part of Bird Spring } \\
\hline 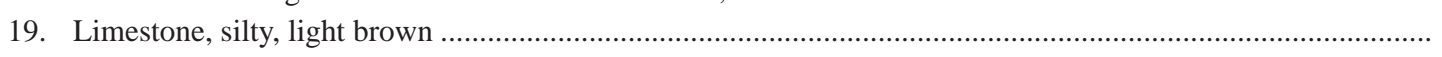 & 0.5 & 122.5 \\
\hline 18. Limestone, light gray, weathers ochre in part & 4.5 & 122.0 \\
\hline 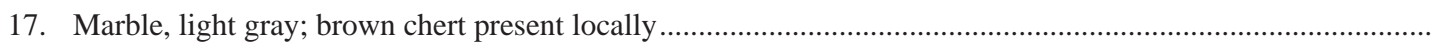 & 6.0 & 117.5 \\
\hline 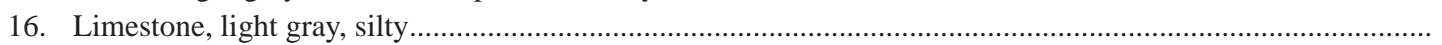 & 0.5 & 111.5 \\
\hline 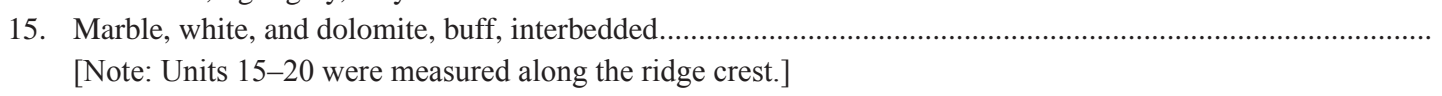 & 10.0 & 111.0 \\
\hline 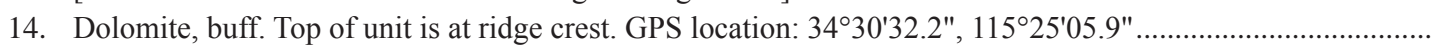 & 7.0 & 101.0 \\
\hline $\begin{array}{l}\text { 7. Dolomite, buff, with relatively thin zones of brown-weathering silty to sandy dolomite at 7.5, 15, and } 20 \mathrm{~m} \\
\text { above base of unit }\end{array}$ & 30.0 & 53.0 \\
\hline 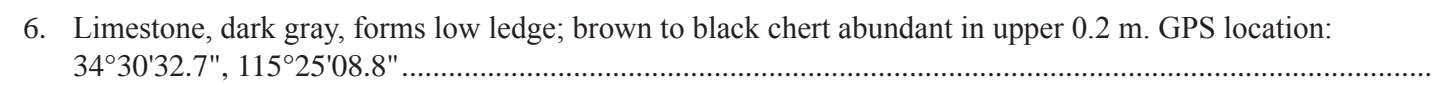 & 1.5 & 23.0 \\
\hline 5. Limestone, silty, light brown, thin bedded, recessive; forms relatively flat area on slope ................................. & 4.0 & 21.5 \\
\hline 4. Dolomite, buff, massive; forms ledge & 17.0 & 17.5 \\
\hline $\begin{array}{l}\text { 3. Limestone, very dark gray, fine to coarse grained; contains irregular brown phosphatic nodules. Sample SM2-1....... } \\
\text { Incomplete thickness of member } 1 \\
\text { Incomplete thickness of Bird Spring Formation }\end{array}$ & $\underline{\underline{0.5}} \underline{\underline{183.0}}$ & 0.5 \\
\hline $\begin{array}{l}\text { Monte Cristo Limestone (Mississippian) (incomplete): } \\
\text { Bullion Member (incomplete): }\end{array}$ & & \\
\hline 2. Limestone, dolomitic, cream colored, laminated, grading up into massive light gray marble.......................... & 6.0 & \\
\hline 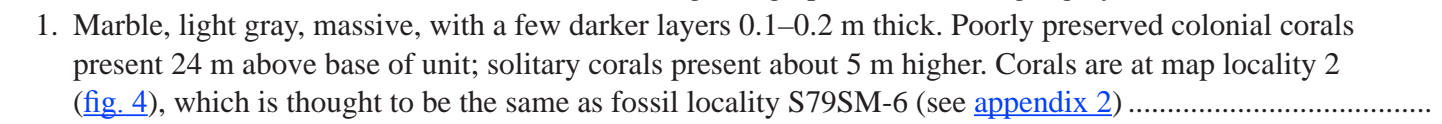 & $\underline{46.0}$ & \\
\hline 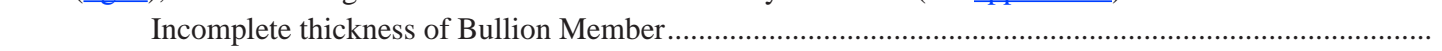 & $\overline{52.0}$ & \\
\hline 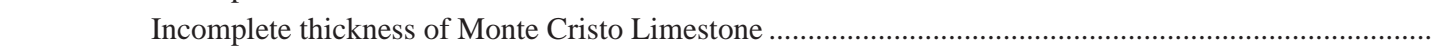 & $\overline{\overline{52.0}}$ & \\
\hline section covered with alluvium on lower part of slope. GPS location: $34^{\circ} 30^{\prime} 34.7^{\prime \prime}, 115^{\circ} 25^{\prime} 10.6^{\prime \prime}$. & & \\
\hline
\end{tabular}




\section{Appendix 2. Fossils}

Fossils were identified from several localities in the Bird Spring Formation in the Ship Mountains study area (fig. 4; table 1). All localities are on hill 1 in the northwestern part of the area, and most are in member 4 and the lower part of member 5 . Two closely spaced fossil localities are in the lower part of member 1. Two additional fossil localities are from the Bullion Member of the Monte Cristo Limestone.

\section{Bullion Member of the Monte Cristo Limestone and Member 1 of the Bird Spring Formation}

In January 1979, Paul Stone and K.A. Howard collected three fossiliferous limestone samples from rocks presently assigned to the Bullion Member of the Monte Cristo Limestone and member 1 of the Bird Spring Formation northeast of the fault on hill 1 (fig. 4). At that time, the age and proper formational assignment of the rocks northeast of the fault were unknown; based on lithologic criteria alone, we thought the rocks might be as old as Devonian. The three samples (S79SM-1, -2, and -6) were submitted to J.T. Dutro, Jr. of the U.S. Geological Survey (USGS) for paleontological analysis in February 1979. Dutro and other USGS specialists analyzed the fossils and reported their results to K.A. Howard at various times in 1979 and 1980. As shown by these reports, samples S79SM-1 and 2 (map locality 3) yielded Early Pennsylvanian (Morrowan) conodonts, indicating that most of the rocks northeast of the fault should be assigned to the Bird Spring Formation. Unidentifiable corals suggesting a possible Mississippian age were recovered from the stratigraphically lower sample S79SM-6 (map locality 2).

More recently, in March 2010, Paul Stone and C.H. Stevens discovered colonial corals at map locality 1, which is at about the same stratigraphic position as sample S79SM6. These corals, although uncollectible, are better preserved than those of sample S79SM-6. Based on field observations, C.H. Stevens identifies these corals as Diphyphyllum aff. $D$. lateseptatum McCoy, which suggests a Middle Mississippian (Visean) age and provides evidence for assigning the enclosing strata to the Monte Cristo Limestone.

\section{USGS Fossil Reports on Samples S79SM-1, -2, and -6}

Sample locality information and pertinent parts of the USGS fossil reports are presented below. The fossil reports are presented in the order in which they were prepared and delivered. Note that the first two reports, on corals and bryozoans, were prepared before the conodont report indicating that samples S79SM-1 and -2 are Pennsylvanian instead of Devonian or Mississippian as was originally suspected.

\section{Sample Localities}

[Collections by Paul Stone and K.A. Howard, January 22, 1979. GPS locations by Paul Stone and C.H. Stevens, March 2010.]

S79SM-1 (USGS 27476-PC). Member 1, Bird Spring Formation, about $20 \mathrm{~m}$ above base; map locality 3. GPS location: $34^{\circ} 30^{\prime} 35.5^{\prime \prime}, 115^{\circ} 25^{\prime} 05.9^{\prime \prime}$.

S79SM-2 (USGS 27475-PC). Same general locality as S79SM-1, about 3 m stratigraphically higher.

S79SM-6 (USGS 27474-PC). Bullion Member, Monte Cristo Limestone, about $28 \mathrm{~m}$ below top; map locality 2. GPS location: $34^{\circ} 30^{\prime} 34.1^{\prime \prime}, 115^{\circ} 25^{\prime} 10.0^{\prime \prime}$.

Corals

[Quoted from a report by W.J. Sando, June 26, 1979] S79SM-6 (USGS 27474-PC)

This report concerns about a dozen poorly preserved solitary corals in chert matrix. The specimens are too poorly preserved for specific or generic identification. Recrystallization of calcitic internal structures prevents positive determination. The age, therefore, is not determinable on these specimens. However, if I had to make a guess, I would lean more toward Mississippian than Devonian for these fossils.

\section{Bryozoans}

[Quoted from a report by O.L. Karklins, October 2, 1979] S79SM-1 (USGS 27476-PC)

Bryozoans present in the thin-sectioned rock are Rhombopora? sp. (4 specimens), and a small fragment of a fenestelloid genus.

Specimens of Rhombopora? in this collection are atypical of this genus. They appear to represent a group of Rhombopora sp. sensu lato that are transitional between certain trepostomes and rhabdomesid cryptostomes in strata of late Paleozoic age. The fenestelloid is fragmentary and indeterminable.

Although the skeletal microstructure of Rhombopora? sp. is not well preserved, the general appearance of these colonies is more suggestive of a Carboniferous (Mississippian?) age than of a Devonian age.

\section{Conodonts}

[Quoted from a report by John Repetski, January 7, 1980. Number of specimens studied is indicated to the right of each taxon in the faunal lists.] 
S79SM-1 (USGS 27476-PC)

Adetognathus cf. A. spathus Dunn

A. spp. (broken) 3

Declinognathodus noduliferus (Ellison and Graves) 17

Idiognathodus delicatus Gunnell 16

I. sp. (broken) 1

Idiognathoides convexus (Ellison and Graves) 6

Neognathodus bassleri (Harris and Hollingsworth) 2

$N$. cf. N. bassleri (Harris and Hollingsworth) (juvenile) 1

indet. juvenile platform elements 3

hindeodelliform (A1) elements 3

ligonodiniform (A2) element $\quad 1$

lonchodiniform (A2) elements 2

neoprioniodiniform $(\mathrm{N})$ elements $\quad 2$

indet. bar elements $\quad 9$

indet. platform elements 13

Age: Early Pennsylvanian (Morrowan)

All the species listed are limited to rocks no older than earliest Pennsylvanian. Idiognathoides convexus is known only from basal to midMorrowan strata. Idiognathodus delicatus and Neognathodus bassleri make their first appearances in the mid-Morrowan, thereby requiring a midMorrowan stratigraphic assignment for this faunule.

The conodont alteration index (CAI) of these elements is 6 , indicating minimum host-rock temperatures of at least $400^{\circ} \mathrm{C}$.

S79SM-2 (USGS 27475-PC)

Adetognathus spp.

Declinognathodus noduliferus (Ellison and Graves)

Idiognathodus delicatus Gunnell

I.? sp. (abraded)

cf. Idiognathoides convexus (Ellison and Graves)

Neognathodus bassleri (Harris and Hollingsworth)

Rachistognathus sp.

indet. bar element

indet. platform elements

Age: Early Pennsylvanian (middle or late Morrowan)

This sample probably is mid-Morrowan as is sample S79SM-1, especially if the broken specimen tentatively assigned to $I$. convexus indeed belongs to that taxon. I. delicatus and $N$. bassleri are not known below the middle Morrowan and $D$. noduliferus is not known from above the upper Morrowan.

CAI-6: minimum host-rock temperature about $400^{\circ} \mathrm{C}$.

\section{Ostracodes}

[Quoted from a report by I.G. Sohn, March 4, 1980]
John Repetski gave me on Jan. 31, 1980, a slide and the light residue of two collections from conodont processing that contain ostracodes. The ostracodes are all steinkerns, so I crushed some undissolved limestone from one of the collections and obtained the same dominant ostracodes. Both assemblages are unique in that they contain in abundance Cavellina, and one or two specimens of an unidentifiable sulcate ostracode that is probably a kloedenellid. Based on these forms the Lower Pennsylvanian age determined by Repetski is neither confirmed nor denied.

S79SM-1 (USGS 27476-PC)

A part of this collection was crushed, and 3 steinkerns of carapaces were recovered, as opposed to the dissolved residue that has yielded more than 100 steinkerns. This indicates that the specimens were concentrated by solution of the limestone.

Cavellina sp., all but one steinkern

Gen. undet. kloedenellid, 1 steinkern

S79SM-2 (USGS 27475-PC)

The dissolved residue contains more than 150 steinkerns of Cavellina, and 1 steinkern of the kloedenellid genus as in no. 27476.

In both samples the Cavellina species is represented by adults and by growth stages, interpreted as indication that the ostracodes lived in the area of limestone deposition in a low energy environment. The abundance of a single species to the virtual exclusion of other taxa is interpreted as lagoon or other high stress environment.

\section{Brachiopods}

[Quoted from a report by J.T. Dutro, Jr., September 25, 1980]

This report covers the brachiopods and other miscellaneous megafossils in two collections from... the Ship Mountains. The fossils are silicified and fragmentary, but all the identifiable species are consistent with the Early Pennsylvanian age which was determined by the conodonts.

S79SM-1 (USGS 27476-PC) bryozoan fragments, indet.

Neochonetes? sp.

Anthracospirifer cf. A. curvilateralis (Easton)

Cleiothyridina cf. C. milleri Sutherland and Harlow

S79SM-2 (USGS 27475-PC)

bryozoan fragments, indet.

Anthracospirifer cf. A. curvilateralis (Easton)

Composita cf. C. ovata Mather

Cleiothyridina? sp.

pelecypod steinkern, indet. 


\section{Members 4 and 5 of the Bird Spring Formation}

\section{Fusulinids and Other Foraminifers}

In April 1978, K.A. Howard and Paul Stone collected fusulinid-bearing bioclastic limestone samples of the Bird Spring Formation from three spot localities in the Ship Mountains (samples KH78-87, -88, -89). In October 1978, Stone collected eight additional samples of fusulinid-bearing limestone from measured section SM (samples SM-18, -23, -24, -25, -27, -28, -33, -35). In February 1979, the 11 fusulinid samples were sent to R.C. Douglass (U.S. Geological Survey) for analysis. Douglass conveyed the results of his analysis in a written report to K.A. Howard dated April 24, 1979. More recently, in December 2003, C.H. Stevens and Paul Stone collected three new samples of fusulinid limestone from spot localities in the Ship Mountains (samples S-1945, -1947, -1948). Taxa identified by C.H. Stevens in the three new samples, in addition to taxa identified through reexamination of the five best samples reported on by Douglass (KH78-87, -89; SM-18, -27 and -35), were listed by Stevens and Stone (2007). The taxa reported below are based on the combined analyses of the 14 total samples by R.C. Douglass and C.H. Stevens. All samples indicate or are consistent with a Cisuralian (early Permian) age corresponding to Fusulinid Zone 3 of Stevens and Stone (2007).

SM-18 (USGS f14063). Measured section SM, upper part of unit 17c, $235 \mathrm{~m}$ above base of section, $12 \mathrm{~m}$ above base of member 4, Bird Spring Formation. Collected by Paul Stone, October 26, 1978. Original analysis by R.C. Douglass; later analysis by C.H. Stevens.

\section{Climacammina sp.}

Pseudofusulinella? sp.

Schubertella aff. S. kingi Dunbar and Skinner

Schwagerina aculeata Thompson and Hazzard

Schwagerina cf. S. aculeata Thompson and Hazzard

Schwagerina longissimoidea (Beede)

SM-23 (USGS f14064). Measured section SM, $3.4 \mathrm{~m}$ above base of unit 20, $264 \mathrm{~m}$ above base of section, $41 \mathrm{~m}$ above base of member 4, Bird Spring Formation. Collected by Paul Stone, October 26, 1978. Analysis by R.C. Douglass.

Ghosts of fusulinids showing the outline but completely replaced interiors.

SM-24 (USGS f14065). Measured section SM, basal part of unit 21b, $271 \mathrm{~m}$ above base of section, $48 \mathrm{~m}$ above base of member 4, Bird Spring Formation. Collected by Paul Stone, October 26, 1978. Analysis by R.C. Douglass.

Ghosts of fusulinids suggesting possible Schwagerina sp. and also a possible small Pseudoschwagerina sp.
SM-25 (USGS f14066). Measured section SM, middle part of unit 21b, $272 \mathrm{~m}$ above base of section, $49 \mathrm{~m}$ above base of member 4, Bird Spring Formation. Collected by Paul Stone, October 26, 1978. Analysis by R.C. Douglass.

Fusulinids altered but barely recognizable as Schwagerina sp. and suggesting S. providens Thompson and Hazzard.

SM-27 (USGS f14067). Measured section SM, upper bedding plane of unit 21b, $273 \mathrm{~m}$ above base of section, $50 \mathrm{~m}$ above base of member 4, Bird Spring Formation. Collected by Paul Stone, October 26, 1978. Original analysis by R.C. Douglass; later analysis by C.H. Stevens.

Climacammina sp.

Schubertella sp.

Schwagerina providens Thompson and Hazzard

Schwagerina cf. S. wellsensis Thompson and Hansen

Stewartina multispira (Thompson and Hazzard)

SM-28 (USGS f14068). Measured section SM, $0.6 \mathrm{~m}$ below top of unit 22, $276 \mathrm{~m}$ above base of section, $53 \mathrm{~m}$ above base of member 4, Bird Spring Formation. Collected by Paul Stone, October 26, 1978. Analysis by R.C. Douglass.

The fusulinids in this sample are replaced leaving essentially structureless ghosts.

SM-33 (USGS f14069). Measured section SM, basal part of unit 26j, $312 \mathrm{~m}$ above base of section, $33 \mathrm{~m}$ above base of member 5, Bird Spring Formation. Collected by Paul Stone, October 26, 1978. Analysis by R.C. Douglass.

Sandy limestone containing a form resembling Pseudoschwagerina? sp. of Thompson and Hazzard (1946) but a little more tightly coiled.

SM-35 (USGS f14070). Measured section SM, basal part of unit 28c, $331 \mathrm{~m}$ above base of section, $52 \mathrm{~m}$ above base of member 5, Bird Spring Formation. Collected by Paul Stone, October 26, 1978. Original analysis by R.C. Douglass; later analysis by C.H. Stevens.

Schwagerina cf. S. wellsensis Thompson and Hansen

Cuniculinella mojavensis Stevens and Stone?

KH78-87 (USGS f14071). Near base of member 4, Bird Spring Formation, map locality 4; probably about the same location as SM-18. Mapped location: $34^{\circ} 30^{\prime} 27^{\prime \prime}, 115^{\circ} 25^{\prime} 13^{\prime \prime}$. Collected by K.A. Howard and Paul Stone, April 16, 1978. Original analysis by R.C. Douglass; later analysis by C.H. Stevens.

Climacammina sp.

Pseudofusulinella sp.

Schubertella aff. S. kingi Dunbar and Skinner

Schwagerina cf. S. aculeata Thompson and Hazzard

Schwagerina aculeata plena Thompson and Hazzard 
KH78-88 (USGS f14072). Lower part of member 4, Bird Spring Formation, not far stratigraphically above KH78-87. Collected by K.A. Howard and Paul Stone, April 16, 1978. Analysis by R.C. Douglass.

Schwagerina sp., a large form not described by Thompson and Hazzard (1946).

KH78-89 (USGS f14073). Upper part of member 4, Bird Spring Formation, probably at or near S-1948 (see location information below). Collected by K.A. Howard and Paul Stone, April 16, 1978. Original analysis by R.C. Douglass; later analysis by C.H. Stevens.

Climacammina sp.

Schubertella sp.

Schwagerina aculeata Thompson and Hazzard?

Schwagerina wellsensis Thompson and Hansen

Pseudoschwagerina sp.

Stewartina uber (Thompson and Hazzard)

Stewartina sp. 1 of Stevens and Stone (2007)

S-1945. Upper part of member 4, Bird Spring Formation, from float stratigraphically just below S-1948 (see below). Collected by C.H. Stevens and Paul Stone, December 4, 2003. Analysis by C.H. Stevens (see Stevens and Stone, 2007). Schwagerina aculeata Thompson and Hazzard Schwagerina cf. S. pugunculus Ross

Schwagerina sp. 4 of Stevens and Stone (2007) Paraschwagerina elongata Skinner and Wilde
S-1947. Lower part of member 5, Bird Spring Formation,

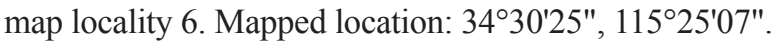
Approximately the same location as SM-35 (see above). Collected by C.H. Stevens and Paul Stone, December 4, 2003. Analysis by C.H. Stevens (see Stevens and Stone, 2007). Schwagerina cf. S. wellsensis Thompson and Hansen Schwagerina sp. 3 of Stevens and Stone (2007)

S-1948. Upper part of member 4, Bird Spring Formation, map locality 5. GPS location: 34³0'22", $115^{\circ} 25^{\prime} 16^{\prime \prime}$. Collected by C.H. Stevens and Paul Stone, December 4, 2003. Analysis by C.H. Stevens (see Stevens and Stone, 2007).

Pseudoschwagerina arta Thompson and Hazzard

\section{Colonial Corals}

The corals listed below were collected by C.H. Stevens and Paul Stone in March 2010 and were identified by C.H. Stevens.

SJS-1366. Upper part of member 4, Bird Spring Formation, map locality 5; same locality as fusulinid sample S-1948 (see location information above).

Tschussovskenia connorsensis (Easton)

Protowentzelella kunthi (Stuckenberg) 


\section{Appendix 3. Petrographic Information}

This appendix presents petrographic descriptions of lithologic samples collected from the upper Paleozoic rocks and some other rock units exposed in the Ship Mountains study area (fig. 4). Most of the samples, including those from measured section SM, were collected by Paul Stone and K.A. Howard in 1978 and 1979. For these samples, only thin sections were examined; the rock samples themselves can no longer be located. For other samples, collected by Paul Stone and C.H. Stevens in 2003 and 2010, both thin sections and rock samples were examined. Stained slabs were prepared for a few of the igneous rock samples. Calc-silicate metamorphic minerals are noted in many metasedimentary rock samples; the main metamorphic minerals present are tremolite and diopside based on a preliminary examination by T.D. Hoisch (this study).

\section{Samples from Measured Section SM}

[Samples are from members 2-5 of the Bird Spring Formation. See appendix 1 and plate 1 for stratigraphic positions of samples.]

SM-1. Member 2; measured unit 2. Field description: Massive white calc-silicate rock. Thin section: Entire section is composed of coarse-grained wollastonite (confirmed by T.D. Hoisch, this study) that forms a complex crystal mosaic, including some radiating crystal clusters.

SM-2. Member 2; measured unit 3d. Field description: Light-gray dolomite that has brown chert bands. Thin section: Medium-grained crystalline dolomite ( 70 percent) having small pores filled with an unidentified mineral of low birefringence (30 percent).

SM-3. Member 2; measured unit 3d. Field description: Massive light-gray dolomite. Thin section: Coarse-grained crystalline dolomite. No siliceous minerals present.

SM-4. Member 2; measured unit 4e. Field description: Medium-gray, aphanitic limestone. Thin section: Fine-grained crystalline calcite having less than 1 percent impurities that are mostly small iron oxide crystals.

SM-5. Member 2; measured unit 7b. Field description: Light-gray marble that has calc-silicate bands. Thin section: Coarse-grained crystalline calcite; thin bands of fibrous minerals that may include both carbonate and calc-silicate minerals; and scattered silt to fine sand size quartz (relict detrital grains?).

The quartz grains are much smaller than the average size of the enclosing carbonate crystals. A minor low-birefringent mineral (wollastonite?) is present in the fibrous clusters.

SM-6. Member 2; measured unit 7c. Field description: Massive white to light-gray marble. Thin section: Coarsegrained crystalline calcite and small pockets of a fibrous, lowbirefringent mineral (wollastonite?).
SM-7. Member 3; measured unit 9a. Field description: Brown-weathering sandy limestone. Thin section: Well sorted, subrounded, fine-grained quartz sand (50 percent); and medium-grained crystalline calcite (50 percent) that grew between and around the sand grains.

SM-8. Member 3; measured unit 9e. Field description: Massive light-gray quartzite, weathers dark brown. Thin section: Medium-grained quartz sand (60 percent) and 40 percent interstitial, pale-green calc-silicate minerals. Calcite forms thin seams.

SM-9. Member 3; measured unit 9h. Field description: Massive quartzite or calc-silicate rock, weathers brown. Thin section: Fine-grained quartz and minor feldspar (plagioclase) sand (60 percent) and pale-green calc-silicate minerals (40 percent).

SM-10. Member 3; measured unit 10b. Field description: Light-gray calcareous sandstone altered to white calc-silicate rock in places. Thin section: Well sorted, fine-grained quartz grains embedded in a fibrous calc-silicate matrix that includes radiating crystal clusters.

SM-11. Member 3; measured unit 11e. Field description: White marble with brown siliceous laminae. Thin section: Coarse-grained crystalline calcite. No siliceous minerals. Minor iron oxide impurities.

SM-12. Member 3; measured unit 12c. Field description: Brown-weathering calc-silicate rock or quartzite. Thin section: Fine-grained quartz and minor feldspar sand (50 percent) and a matrix of tabular to fibrous calc-silicate(?) minerals that locally form radiating crystal clusters. Irregular calcite seams.

SM-13. Member 3; measured unit 13a. Field description: Light-gray quartzite, weathers dark brown. Thin section: Finegrained quartz sand (50 percent) and a pale green calc-silicate mineral.

SM-14. Member 3; measured unit 13b. Field description: Brown-weathering calc-silicate rock. Thin section: Calcite (60 percent) and a fibrous calc-silicate(?) mineral forming radiating clusters and patchworks between calcite crystals.

SM-15. Member 3; measured unit 14b. Field description: Light-gray calc-silicate rock. Thin section: Mixture of pure crystalline calcite and a fibrous to tabular, low-birefringent, mostly very fine grained calc-silicate(?) mineral.

SM-16. Member 3; measured unit 15c. Field description: Light-gray calcareous sandstone, weathers dark brown. Thin section: Fine-grained quartz and minor feldspar sand in a matrix of crystalline calcite and a light-green calc-silicate mineral.

SM-18. Member 4; measured unit 17c. Field description: Micritic limestone containing abundant fusulinids in upper $0.3 \mathrm{~m}$. Thin section: Fusulinids enclosed in dense packstone 
matrix containing abundant small foraminera and echinoderm debris. Most bioclasts are medium sand size; one echinoderm fragment is $1.5 \mathrm{~mm}$ across. Fusulinid walls are micritized but well defined; chambers are filled with sparry calcite.

SM-24. Member 4; measured unit 21b. Field description: Medium dark gray fossiliferous limestone. Thin section: Predominantly fine-grained crystalline calcite (recrystallized micrite). Scattered bioclasts include echinoderm debris and almost completely recrystallized fusulinids. Rare ( $<1$ percent) quartz sand grains.

SM-28. Member 4; measured unit 22. Field description: Medium dark gray fossiliferous limestone. Thin section: Fine-grained calcite matrix enclosing abundant recrystallized bioclasts, mostly small shell fragments and echinoderm debris. Rare quartz sand.

SM-29. Member 5; measured unit 25d. Field description: Fine-grained limestone, nearly white, weathers light gray to grayish orange. Thin section: Very fine grained calcite and minor iron oxide impurities.

SM-30. Member 5; measured unit 26a. Field description: Light-gray dolomite or limestone. Thin section: Very fine grained calcite or dolomite; scattered quartz silt to fine sand; and scattered iron oxides of silt to fine sand size.

SM-31. Member 5; measured unit 26g. Field description: Light-gray, fine-grained sandy limestone. Thin section: Medium- to coarse-grained crystalline calcite (75 percent) and fine- to medium-grained quartz sand ( 25 percent).

SM-32. Member 5; measured unit 26i. Field description: Light-gray calc-silicate rock. Thin section: Calcite and colorless to pale green calc-silicate minerals. No obvious quartz is present.

SM-34. Member 5; measured unit 27g. Field description: Light-gray quartzite, fine-grained, weathers dark brown. Thin section: Quartz (75 percent) and pale-green calc-silicate mineral (25 percent). Quartz is fine-grained, forming mostly interlocking crystals with sutured grain boundaries.

SM-35. Member 5, measured unit 28c. Field description: Aphanitic limestone containing locally abundant fusulinids and other fossil debris. Thin section: Limestone containing large fusulinids in a partially recrystallized micritic matrix. Fusulinid tests are completely micritized; chambers are filled with sparry calcite. Scattered echinoderm debris is present. Texture is wackestone.

SM-36. Member 5; measured unit 29d. Field description: Dolomite, fine-grained, reddish gray, weathers light gray. Thin section: Very fine grained dolomite that has less than 5 percent iron oxide grains.
SM-37. Member 5; measured unit 29f. Field description: Dolomite like SM-36. Thin section: Very fine-grained dolomite containing 1-2 percent quartz silt to very fine grained sand. Scattered hexagonal crystals of iron oxide.

SM-38. Member 5; measured unit 34a. Field description: Light-gray, very fine grained dolomite. Thin section: Very fine grained dolomite containing 1 percent (or less) quartz silt to very fine grained sand.

SM-39. Member 5; measured unit 34a. Field description: Dolomite, similar to SM-38. Thin section: Very fine grained dolomite containing 1-2 percent quartz silt to very fine grained sand.

SM-40. Member 5; measured unit 35e. Field description: Limestone, fine to medium grained, grayish orange. Thin section: Rock is composed mainly ( 75 percent) of very fine grained calcite. About 25 percent of rock is composed of sand-size grains or pore fillings of a fibrous, low-birefringent mineral with parallel or very low angle extinction.

SM-41. Member 5; measured unit 38a. Field description: Calcareous quartzite, very fine grained, light gray, weathers dark brown. Thin section: Quartz and minor feldspar silt to fine-grained sand (50 percent) and calcite (50 percent). Alternating laminae are relatively rich and poor in terrigenous sand. Some probable detrital sand-size calcite grains. Quartz grain boundaries are mostly irregular and corroded. No obvious calc-silicate minerals.

SM-44. Member 5; measured unit 40f. Field description: Limestone, medium gray to grayish orange, fine grained, in part silty and sandy. Thin section: Very fine grained crystalline calcite (70 percent), and quartz silt to very fine sand (30 percent). Probably a recrystallized silty to sandy calcarenite. One relatively large detritial zircon grain was observed. Tiny needles (tremolite?), visible only at high power, are scattered throughout the thin section.

SM-50. Member 5; measured unit 44a. Field description: Dolomite, fine grained, grayish orange. Thin section: Composed mostly of very fine grained dolomite containing scattered quartz silt to fine sand. Calc-silicate minerals also present.

SM-51. Member 5; measured unit 44a. Field description: Limestone, fine grained, medium gray. Thin section: Very fine grained calcite; no quartz present.

SM-52. Member 5, measured unit 44a. Field description: Very fine grained calcareous quartzite. Thin section: Approximately equal amounts of detrital quartz (silt to very fine sand) and finely crystalline calcite. Quartz grain boundaries are mostly sutured or corroded. Colorless calc-silicate(?) minerals form about 10 percent of thin section. 
SM-53. Member 5, measured unit 44a. Field description: Limestone, fine grained, grayish orange. Thin section: Composed mostly of very fine grained crystalline calcite. Scattered relatively large crystals of muscovite(?). Small irregular patches of low-birefringent mineral clusters, possibly silica or recrystallized clay minerals.

SM-54. Member 5, measured unit 45a. Field description: Quartzite, calcareous, very fine grained, weathers rusty brown. Thin section: Well sorted, fine- to medium-grained quartz and minor feldspar sand (60 percent) in a crystalline calcite cement or matrix (40 percent). Quartz grain to grain boundaries are sutured. Detrital zircon and opaque mineral grains are abundant in two prominent laminae. Minor calc-silicate minerals.

SM-55. Member 5, measured unit 45b. Field description: Limestone, medium gray, fine grained. Thin section: Finely crystalline calcite and recrystallized tabular grains of unknown origin as long as $1.5 \mathrm{~mm}$. The remnant tabular grains are most visible in plane light.

SM-56. Member 5; measured unit 45b. Field description: Limestone, grayish orange, fine grained. Thin section: Finely crystalline calcite (70 percent) and relatively large crystals of either fibrous calcite or a different fibrous mineral (30 percent) characterized by fine cleavage or twin planes parallel with the long axis. Iron oxide impurities give the rock an overall yellowish color.

SM-57. Member 5; measured unit 46. Field description: Dolomite, very fine grained, grayish orange. Thin section: Finegrained crystalline dolomite and 1 percent (or less) quartz silt.

\section{Samples from Measured Section SM2}

[Note: Samples are from member 1 of the Bird Spring Formation. See appendix 1 and plate 1 for stratigraphic positions of samples.]

SM2-1. Measured unit 3. Field and hand-sample description: Fine-grained limestone; brown phosphatic(?) clasts present in parts of unit. Thin section: Fine-grained crystalline calcite (probably recrystallized) containing minor sand-size echinoderm debris. Thin section (grain mount) of heavy mineral separate after sample was dissolved in acetic acid and floated in bromoform: Almost all grains are brown echinoderm debris, with well preserved skeletal structure. Grains are nearly isotropic. X-ray diffraction analysis of the heavy-mineral residue confirms a composition of fluorapatite (J.R. Hein, written commun., 2010).

SM2-2. Measured unit 8. Field and hand-sample description: Limestone, silty to sandy, laminated, very light greenish gray on fresh surface; weathers dark brown. Thin section: Laminated rock composed of 60 percent fine-grained calcite, 30 percent quartz silt to fine-grained sand, and 10 percent calcsilicate minerals. Some calcite shows a detrital texture.

\section{Samples from Spot Localities}

[Samples are from various map units in the study area (fig. 4). GPS coordinates are given where available.]

\section{Bird Spring Formation}

\section{Member 1}

10-SM-04. Basal limestone unit (equivalent to unit 3, measured section SM2). Hand sample: Dark limestone that has a clastic texture, showing large dark clasts (small pebble size) in a matrix of abundant dark, sand-size clasts in a lighter matrix. Thin section: Matrix is mostly medium-grained calcite forming elongate crystals with wavy, sutured boundaries. Scattered brown grains of medium to coarse sand size include altered crinoid stems; these grains are nearly isotropic and are interpreted to be phosphatic. Thin section includes part of a large brown clast (small pebble) composed of phosphatized crinoid stems, phosphatic(?) peloids of unknown origin, and crystalline calcite. GPS location: $34^{\circ} 30^{\prime} 32.8^{\prime \prime}, 115^{\circ} 25^{\prime} 09.8^{\prime \prime}$.

10-SM-06. Fossiliferous limestone unit about $20 \mathrm{~m}$ above base of member (same bed as unit 6 , measured section SM2). Hand sample: Brownish-gray limestone containing fossil material, including brachiopods. Thin section: Finely crystalline calcite matrix that encloses abundant recrystallized shell fragments and crinoid debris ranging from sand size to $>3 \mathrm{~mm}$. Wackestone texture; fossils float in matrix. Largest observed crinoid stem is $1.5 \mathrm{~mm}$ in diameter. GPS location: $34^{\circ} 30^{\prime} 35.5^{\prime \prime}, 115^{\circ} 25^{\prime} 05.9^{\prime \prime}$. [Note: this is map locality 3 , fig. 4.]

\section{Member 3}

10-SM-39. Basal part of member. Hand sample: Fine-grained calcareous sandstone or calc-silicate rock; light greenish gray fresh, brown weathered. Thin section: Well sorted, finegrained quartz sand in a matrix of calcite and calc-silicate minerals. GPS location: $34^{\circ} 30^{\prime} 21.2^{\prime \prime}, 115^{\circ} 25^{\prime} 24.8^{\prime \prime}$.

\section{Member 4}

[All samples are bioclastic limestone.]

KH78-87. Lower part of member. Thin section: Fusulinid limestone containing abundant small foraminifera and shell fragments. Matrix, composed primarily of fine-grained crystalline calcite (recrystallized micrite), is murky, impure, and brownish due to iron oxide. Fusulinid chambers filled with sparry calcite. Fusulinid wall structure is locally preserved despite partial recrystallization. Large calcite crystals surrounded by matrix are probably echinoderm fragments.

KH78-88. Lower part of member, not far stratigraphically above 87 . Thin section: Micritic limestone containing fusulinids and other bioclasts, especially shell fragments. Matrix cloudy, composed of finely crystalline calcite. Some 
echinoderm debris is present. Fusulinid wall structure preserved locally; micritized elsewhere. Fusulinid chambers filled with sparry calcite.

KH-78-89. Upper part of member. Thin section: Very finely crystalline calcite matrix encloses fusulinids and other bioclasts including small foraminifera and echinoderm debris. Spar in chambers much coarser than crystalline calcite matrix. Siliceous patches present locally.

S-1945. Upper part of member. Thin section: Fusulinids, echinoderm debris, and other small bioclasts in a murky micritic limestone matrix. Echinoderm fragments locally replaced by fan-like crystal growths of an unidentified metamorphic mineral (light brown in plane light; high-order interference colors).

S-1948. Upper part of member. Thin section: Large fusulinids (Pseudoschwagerina) in a very fine grained calcite matrix darkened by impurities. Fusulinids are partially replaced by irregular patches of the same metamorphic mineral seen in S-1945 (yellowish brown in plane light; high-order interference colors; complex crystal patterns).

\section{Member 5}

10-SM-19. Upper part of member, along line of measured section SM (measured unit 40d). Hand sample: Finely crystalline light-greenish-gray rock containing scattered brown grains. Thin section: Solid mat of tabular to stubby crystals $1 \mathrm{~mm}$ long and smaller; birefringence low to moderate (firstand second-order interference colors). Probably all calcsilicate minerals. GPS location: $34^{\circ} 30^{\prime} 19.5^{\prime \prime}, 115^{\circ} 24^{\prime} 58.5^{\prime \prime}$.

10-SM-20. Upper part of member, along line of measured section SM (top of measured unit 41f). Hand sample: Darkgray limestone, fine grained, containing scattered echinoid spines. Thin section: Matrix is micritic calcite, partly recrystallized; some sand-size crinoid debris is present. Large echinoid spines (cross-sectional view) are silicified. GPS location: $34^{\circ} 30^{\prime} 16.6^{\prime \prime}, 115^{\circ} 25^{\prime} 01.3^{\prime \prime}$.

10-SM-26. Lower part of member, equivalent to unit 26i of measured section SM. Hand sample: Fine-grained sandstone or calc-silicate rock; light gray where fresh, light brown where weathered. Thin section: Thoroughly metamorphosed rock composed of fine-grained intergrowths of calc-silicate minerals, quartz, and calcite. No orginal grains preserved. GPS location: $34^{\circ} 30^{\prime} 27.1^{\prime \prime}, 115^{\circ} 25^{\prime} 04.8^{\prime \prime}$.

10-SM-27. Lower part of member, equivalent to unit 27g of measured section SM. Hand sample: Fine-grained calcareous sandstone or calc-silicate rock; light gray fresh, light brown weathered. Thin section: Medium- to coarse-grained quartz sandstone (to $0.5 \mathrm{~mm}$ diameter) containing calcite cement and calc-silicate minerals between quartz grains. Also many sutured boundaries between adjacent quartz grains. GPS location: $34^{\circ} 30^{\prime} 26.9^{\prime \prime}, 115^{\circ} 25^{\prime} 03.4^{\prime \prime}$.

S-1947. Bird Spring Formation, lower part of member. Hand sample: Bioclastic limestone. Thin section: Very fine grained limestone containing highly recrystallized fusulinids, echinoderm debris, and other bioclasts.

\section{Moenkopi Formation (Triassic)?}

10-SM-32. Middle part of unit. Hand sample: Fine-grained calcareous sandstone or calc-silicate rock; light greenish gray where fresh, brown where weathered. Thin section: Mostly fine-grained quartz sand in a matrix of chert, calcite, and calcsilicate minerals. Scattered rounded quartz sand grains $0.3-0.5$ $\mathrm{mm}$ in diameter. Quartz and calcite are approximately equal in abundance. GPS location: 34³0'09.8", 115²4'55.6".

10-SM-33. Lowermost part of unit. Hand sample: Finegrained calcareous sandstone or calc-silicate rock; light greenish gray where fresh, brown where weathered. Thin section: Fine-grained quartz sand in a crystalline calcite matrix or cement. Quartz and calcite are approximately equal in abundance. GPS location: 34³0'09.9", 115²4'56.7".

H79-49a-f. Series of thin sections through unit, showing variations in composition and grain size.

H79-49a. Laminated quartzose sandstone composed of alternating laminae relatively rich and poor in metamorphic calc-silicate minerals. Laminae having fewer metamorphic minerals are finer grained and have a cherty appearance. Quartz sand is fine grained (maximum diameter $\sim 0.125 \mathrm{~mm}$ ). Fine- to coarse-grained crystalline calcite forms irregular patches.

H79-49b. Same lithology as 49a although somewhat coarser grained; maximum diameter of sand grains is $\sim 0.175 \mathrm{~mm}$.

H79-49c. Calcareous quartzite, fine to medium grained, maximum grain diameter $\sim 0.175 \mathrm{~mm}$. Sand grains are tightly packed; most grain boundaries are sutured. Matrix of crystalline calcite and minor calc-silicate minerals forms 20 percent of rock.

H79-49d. Composed dominantly of a pale-green calc-silicate mineral that forms subequant to tabular crystals; minor chert and calcite. Crystalline calcite forms discrete seams or laminae.

H79-49e. Rock is distinctly laminated, with alternating laminae of different grain size and calc-silicate mineral content. Finer grained layers are siliceous, chert-like, with relatively few calc-silicate minerals. Coarser layers are fineto medium-grained quartzose sandstone that has a chert-like matrix and more abundant calc-silicate minerals. One layer is 
composed completely of a coarse-grained calc-silicate mineral forming stubby to blade-shaped crystals.

H79-49f. Calcareous quartz sandstone, the least altered rock in the sequence. Quartz is fine to medium grained (maximum diameter $0.25 \mathrm{~mm}$ ), subangular to subrounded. Calcite cement forms 25 percent of rock; most quartz grains do not touch any other grains. Feldspar sand, including microcline, is minor. No calc-silicate minerals present.

\section{Porphyritic Quartz Monzonite (map unit Jqm; Jurassic)}

10-SM-36. Hand sample: Granitoid rock that has a dark groundmass and light pinkish gray phenocrysts. Stained slab: Large, yellow-stained potassium feldspar phenocrysts (to $2 \mathrm{~cm}$ long) in a medium-grained groundmass (average crystal size $1-5 \mathrm{~mm}$ ) of plagioclase (deep pink stain), quartz, and mafic minerals. Overall, plagioclase and potassium feldspar are present in approximately equal amounts; quartz is much less abundant. Thin section: Plagioclase has well preserved twin lamellae; potassium feldspar is microcline (crosshatch twinning). Some plagioclase is cloudy, sericitic. Quartz is minor. Quartz and feldspar locally show graphic intergrowth texture. Mafic minerals (15-20 percent of rock) are mostly hornblende that is almost entirely altered to epidote and chlorite. Accessory minerals include sphene (conspicuous; grain size $0.5-1 \mathrm{~mm}$ ), zircon, apatite, and iron oxides (magnetite?). GPS location: $34^{\circ} 30^{\prime} 02.4^{\prime \prime}, 115^{\circ} 24^{\prime} 47.3^{\prime \prime}$.

\section{Altered Porphyritic Diorite Dike (map unit Jpd; Jurassic?)}

10-SM-35. Hand sample: Light-gray igneous rock that has a fine-grained groundmass and 40 percent light-gray feldspar phenocrysts to $5 \mathrm{~mm}$ across. Stained slab: Plagioclase phenocrysts are stained very light pink; groundmass generally unstained. Thin section: Groundmass mostly altered plagioclase, grains less than $1 \mathrm{~mm}$ (average size $~ 0.15$ $\mathrm{mm}$ ), tabular, with twinning partly preserved. Anhedral dark minerals, all altered, fill in between the plagioclase grains. Phenocrysts are highly altered plagioclase. No quartz present. GPS location: $34^{\circ} 30^{\prime} 11.2^{\prime \prime}, 115^{\circ} 24^{\prime} 57.0^{\prime \prime}$.

10-SM-38. Hand sample: Igneous rock that has a dark, fine-grained groundmass and 40 percent light greenish-gray feldspar phenocrysts to $5 \mathrm{~mm}$ long. Stained slab: Plagioclase phenocrysts (light purple stain) in a groundmass of plagioclase (light purple stain) and dark minerals. Thin section: Plagioclase-rich groundmass (average grain size $\sim 0.03 \mathrm{~mm}$ ) encloses altered (sericite, chlorite) plagioclase phenocrysts
1-5 mm long. Opaque minerals abundant in groundmass, forming about 10 percent of rock. Groundmass also contains abundant dark, cryptocrystalline impurities. GPS location: 34³0'12.6", 115²4'53.2".

H79-50. Hand sample not available. Thin section: Plutonic rock composed primarily of variably altered feldspar, mainly plagioclase, which varies from nearly fresh to completely replaced or altered. Little if any quartz is present. Irregular crystals or patches of high birefringence (epidote?) forms 10 to 20 percent of rock. Main replacement mineral in plagioclase (clinozoisite?) is very pale green, has high relief and low birefringence, and forms fibrous to tabular crystals with and parallel twin planes.

H79-50a. Hand sample not available. Thin section: Porphyritic, plagioclase-rich plutonic rock, similar to H79-50. Groundmass is fine-grained plagioclase and alteration minerals. Phenocrysts are saussuritized plagioclase crystals as much as $6 \mathrm{~mm}$ long. Minor secondary calcite is present. Tremolite or a similar, colorless mineral that has bright first- and second-order interference colors makes up 5 percent of rock.

\section{Fine-Grained Diorite Dike (map unit Jfd; Jurassic?)}

10-SM-21. Hand sample: Dark, fine-grained, nonporphyritic igneous rock. Stained slab: Mostly light pink (plagioclase); less abundant mafic grains stand out well on stained surface. Thin section: Rock is dominantly plagioclase, in tabular crystals mostly less than $1 \mathrm{~mm}$ long. Plagioclase is well preserved, showing little alteration. Small opaque and mafic grains make up 30 percent of rock. Rare mafic phenocrysts to $1.5 \mathrm{~mm}$ long may be altered clinopyroxene. Epidote, biotite(?), and secondary quartz present in minor amounts. GPS location: $34^{\circ} 30^{\prime} 15.2^{\prime \prime}, 115^{\circ} 25^{\prime} 00.7^{\prime \prime}$.

\section{Peach Spring Tuff (Miocene)}

10-SM-16. Hand sample: Crystal-lithic tuff, strongly lithified, light gray where fresh, brown where weathered; massive; contains conspicuous sanidine phenocrysts. Thin section: None. GPS location: $34^{\circ} 30^{\prime} 24.4^{\prime \prime}, 115^{\circ} 24^{\prime} 58.3^{\prime \prime}$.

KH78-92. Hand sample not available. Thin section: Groundmass of altered shards encloses phenocrysts and subordinate lithic clasts $5 \mathrm{~mm}$ in diameter and smaller. Phenocrysts include sanidine, plagioclase, biotite, quartz, sphene, hornblende, opaque minerals, and accessory apatite and zircon. Largest lithic clast is a piece of granitic rock composed of coarse-grained plagioclase and minor biotite. 
Publishing support provided by the U.S. Geological Survey

Publishing Network, Menlo Park and Tacoma Publishing Service Centers

For additional information contact:

Director, Geology, Minerals, Energy, and Geophysics

Science Center

U.S. Geological Survey

345 Middlefield Road

Menlo Park, CA 94025-3591

http://geomaps.wr.usgs.gov/gmeg/ 


\section{कू
क}

胥

言

学

$\frac{\overline{0}}{\omega}$

$\stackrel{9}{*}$

产

흘

言

尊

边

产.

象

흉

产

$\stackrel{\circ}{\equiv}$

तั

믈

䈝

뭉

ग)

홀

\%

홀 